\title{
Progresses on the Optimal Processing and Properties of Highly Porous Rare Earth Silicate Thermal Insulators
}

\author{
Zhen Wu, Luchao Sun, and Jingyang Wang ${ }^{\dagger}$ \\ High-Performance Ceramics Division, Institute of Metal Research, Chinese Academy of Sciences, Shenyang 110016, China \\ (Received November 5, 2018; Accepted November 7, 2018)
}

\begin{abstract}
High-temperature thermal insulation materials challenge extensive oxide candidates such as porus $\mathrm{SiO}_{2}, \mathrm{Al}_{2} \mathrm{O}_{3}$, yttria-stabilized zirconia, and mullite, due to the needs of good mechanical, thermal, and chemical reliabilities at high temperatures simultaneously. Recently, porous rare earth (RE) silicates have been revealed to be excellent thermal insulators in harsh environments. These materials display attractive properties, including high porosity, moderately high compressive strength, low processing shrinkage (near-net-shaping), and very low thermal conductivity. The current critical challenge is to balance the excellent thermal insulation property (extremely high porosity) with their good mechanical properties, especially at high temperatures. Herein, we review the recent developments in processing techniques to achieve extremely high porosity and multiscale strengthening strategy, including solid solution strengthening and fiber reinforcement methods, for enhancing the mechanical properties of porous RE silicate ceramics. Highly porous RE silicates are highlighted as emerging high-temperature thermal insulators for extreme environments.
\end{abstract}

Key words : Porous rare earth silicate ceramics, Thermal insulation materials, Preparation methods, Microstructure, Properties

\section{Introduction}

$\mathbf{P}$ orous ceramics are an important class of materials in industrial production and human life. They have attracted a great deal of attention owing to their unique advantages such as good high-temperature resistance, good corrosion resistance, low density, low thermal conductivity, high permeability, and high specific strength. ${ }^{1-5)}$ Therefore, porous ceramics have been widely used in many fields, including filtration of molten metals and hot corrosive gases, chemical sensors, solid oxide fuel cells, catalysts and catalyst carriers, aeration of liquids, bacteria immobilization, and thermal insulators. ${ }^{6-10)}$

Among the various applications, porous ceramics play an important role in thermal insulation. At present, the common porous ceramics used as thermal insulators are porous $\mathrm{SiO}_{2}, \mathrm{Al}_{2} \mathrm{O}_{3}$, mullite, and yttria-stabilized zirconia (YSZ). These traditional materials have their respective advantages, however, they also have drawbacks, such as a low compressive strength (5.82 MPa, porosity: $\mathrm{P}=70.1 \%)$ and a low operating temperature $\left(\sim 1200^{\circ} \mathrm{C}\right)$ for porous $\mathrm{SiO}_{2}$ ceramic; ${ }^{11-13)}$ high thermal conductivities $[0.8 \mathrm{~W} /(\mathrm{m} \cdot \mathrm{K}), \mathrm{P} \approx$ $73 \%$ and $1.2 \mathrm{~W} /(\mathrm{m} \cdot \mathrm{K}), \mathrm{P} \approx 66 \%$ ] for porous $\mathrm{Al}_{2} \mathrm{O}_{3}$ ceramic; ${ }^{14-}$ 16) a low strength (5.24 $\mathrm{MPa}, \mathrm{P}=80.3 \%)$ for porous mullite ceramic, ${ }^{17,18)}$ as well as high sintering linear shrinkages

\footnotetext{
${ }^{\dagger}$ Corresponding author : Jingyang Wang

E-mail : jywang@imr.ac.cn

Tel : +86-24-2397-1762 Fax : +86-24-2389-1320
}

$\left(15 \%\right.$ at $1550^{\circ} \mathrm{C}, \mathrm{P}=45 \%$ and $31.8 \%$ at $\left.1550^{\circ} \mathrm{C}, \mathrm{P}=65 \%\right)$ and a high density $\left(1.2 \mathrm{~g} / \mathrm{cm}^{3}, \mathrm{P}=80 \%\right)$ for porous YSZ. $\left.{ }^{19,20}\right)$ Hence, the new focus of porous ceramic research is to seek novel matrix materials with better properties.

\section{Novel Matrix Materials-Rare Earth Silicates}

An excellent (high-temperature) thermal insulator primarily must have the features of good high-temperature resistance and low thermal conductivity. Therefore, the new matrix of a porous ceramic should be a material that has a high melting point, good thermal stability, and low thermal conductivity. Rare earth silicates are a class of materials that exhibit high melting point, low thermal conductivity, and good thermal and chemical stability at high temperatures. ${ }^{21-24)}$ Hence, they have been chosen as a novel matrix material for thermal insulation owing to their outstanding properties, and porous rare earth silicate ceramics have recently become the new direction of research in the field of porous ceramic thermal insulators. ${ }^{25-31)}$

There are two stable phases of rare earth silicates: $\mathrm{RE}_{2} \mathrm{SiO}_{5}$ (monosilicates) and $\mathrm{RE}_{2} \mathrm{Si}_{2} \mathrm{O}_{7}$ (disilicates). ${ }^{32,33)}$ In this regard, there has been more research on yttrium silicates because of their abundant reserves and relatively lower prices. Specifically, $\mathrm{X} 2-\mathrm{Y}_{2} \mathrm{SiO}_{5}$ and $\gamma-\mathrm{Y}_{2} \mathrm{Si}_{2} \mathrm{O}_{7}$ are the most stable high-temperature phases that have better properties compared with their various polymorphs. ${ }^{34-36)}$ Therefore, $\mathrm{X} 2-\mathrm{Y}_{2} \mathrm{SiO}_{5}$ and $\gamma-\mathrm{Y}_{2} \mathrm{Si}_{2} \mathrm{O}_{7}$ have been applied as the matrix materials of porous thermal insulators. ${ }^{25-30,37-40)} \mathrm{Sim}$ - 
ilarly, $\mathrm{Yb}_{2} \mathrm{SiO}_{5}$ has an extremely low thermal conductivity $\left(<1.3 \mathrm{~W} /(\mathrm{m} \cdot \mathrm{K})\right.$ above $\left.1000^{\circ} \mathrm{C}\right),{ }^{24)}$ and has also been prepared to a porous ceramic. ${ }^{41,42)} \gamma-\left(\mathrm{Y}_{1-\mathrm{x}} \mathrm{Ho}_{\mathrm{x}}\right)_{2} \mathrm{Si}_{2} \mathrm{O}_{7}$ solid solution is also used as a matrix material of porous ceramic and exhibits good room- and high-temperature performances. ${ }^{43)}$

\subsection{Crystal structures and properties of $\mathrm{X} 2-\mathrm{RE}_{2} \mathrm{SiO}_{5}$}

As we know, $\mathrm{Y}$ is a kind of representative rare earth element, and is chose as an example to illustrate rare earth monosilicates. $\mathrm{Y}_{2} \mathrm{SiO}_{5}$ has two polymorphs: X1 (low-temperature phase, $<1190^{\circ} \mathrm{C}$ ) and $\mathrm{X} 2$ (high-temperature phase, $\left.>1190^{\circ} \mathrm{C}\right){ }^{35}$ ) Because there is no phase transformation between room temperature and the melting point of $\mathrm{X} 2$ phase, it is beneficial for thermal insulation, and $\mathrm{X} 2-\mathrm{Y}_{2} \mathrm{SiO}_{5}$ is a suitable porous ceramic matrix. Fig. 1 shows the crystal structure of the high-temperature phase of $\mathrm{Y}_{2} \mathrm{SiO}_{5}$ (hereafter simply referred to as $\mathrm{Y}_{2} \mathrm{SiO}_{5}$ for brevity). It belongs to the $B 2 / b$ space group and monoclinic system. The unit cell contains 64 atoms (eight formulas). Nonequivalent atomic sites consist of two Y sites (Y1 and Y2), one Si site, and five $\mathrm{O}$ sites (O1-O5). $\mathrm{Y} 1$ and $\mathrm{Y} 2$ coordinate with six or seven $\mathrm{O}$ atoms and form $\mathrm{YO}_{6}$ or $\mathrm{YO}_{7}$ polyhedron, respectively. Four $\mathrm{O}(\mathrm{O} 1-\mathrm{O} 4)$ atoms and a $\mathrm{Si}$ atom at the centre form a $\mathrm{SiO}_{4}$ tetrahedron, while the $\mathrm{O} 5$ atom is loosely bonded to four $\mathrm{Y}$ atoms, with no $\mathrm{Si}$ atom in the nearest-neighborhood. ${ }^{44-46)}$

The reason why $\mathrm{Y}_{2} \mathrm{SiO}_{5}$ attracts a great deal of attention is that it exhibits many excellent properties such as high melting point $\left(1950^{\circ} \mathrm{C}\right),{ }^{21)}$ low oxygen permeability $\left(10^{-10} \mathrm{~kg} /\right.$ $(\mathrm{m} \cdot \mathrm{s}))$ at temperatures up to $1700^{\circ} \mathrm{C},{ }^{47)}$ low dielectric constan (3.4), ${ }^{48)}$ good chemical and thermal stability, ${ }^{23,49,50)}$ and good damage tolerance. ${ }^{51)}$ As mentioned before, $\mathrm{Y}_{2} \mathrm{SiO}_{5}$ does not undergo a phase transformation between room temperature and its melting point. In particular, $\mathrm{Y}_{2} \mathrm{SiO}_{5}$ has a very low thermal conductivity $\left(<1.4 \mathrm{~W} /(\mathrm{m} \cdot \mathrm{K}),>900^{\circ} \mathrm{C}\right)$, which is lower than those of most common thermal barrier coating materials such as YSZ, as shown in Fig. $2 .^{24,52)}$ It would be highly advantageous for a thermal insulation material to have a low starting value of thermal conductivity and extremely good heat-insulating property.

$\mathrm{Yb}_{2} \mathrm{SiO}_{5}$ has only one crystal form, namely the $\mathrm{X} 2$ phase, owing to the small ionic radius of $\mathrm{Yb} .{ }^{36}$ ) The crystal structure of $\mathrm{Yb}_{2} \mathrm{SiO}_{5}$ is the same as that of $\mathrm{X} 2-\mathrm{Y}_{2} \mathrm{SiO}_{5}$, belonging

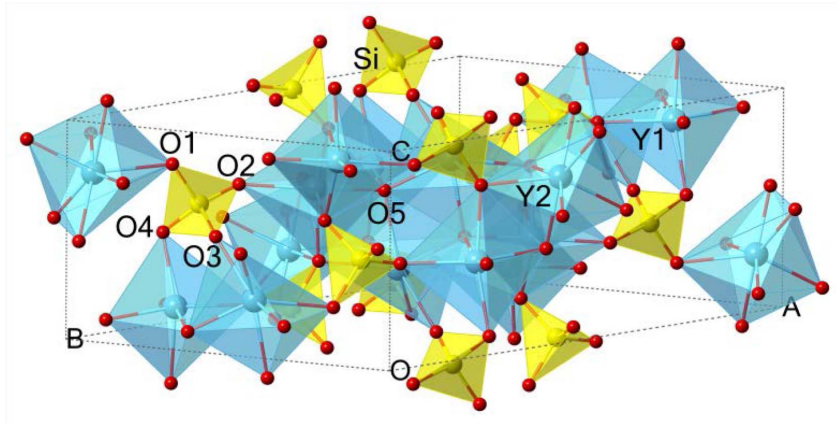

Fig. 1. Crystal structure of $\mathrm{X} 2-\mathrm{Y}_{2} \mathrm{SiO}_{5}$. Reproduced with permission from reference. ${ }^{45}$

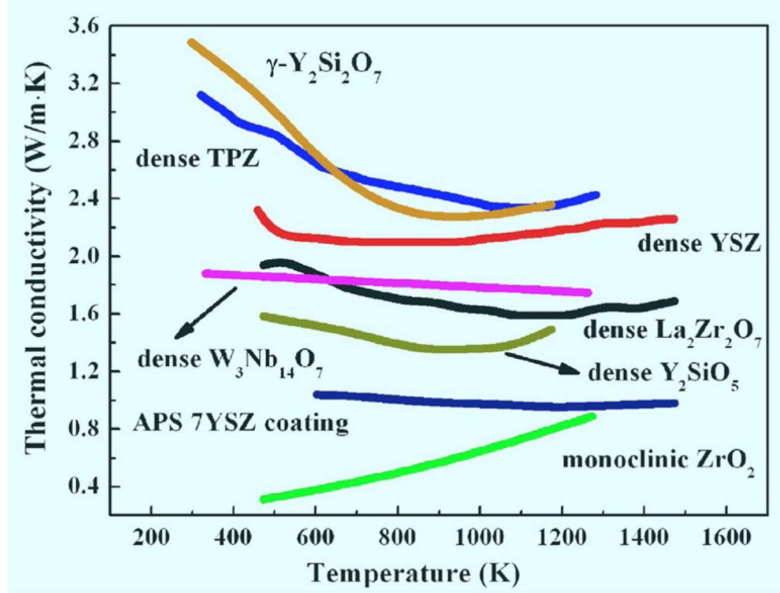

Fig. 2. Thermal conductivity of $\mathrm{Y}_{2} \mathrm{SiO}_{5}$ and its comparison with other low thermal conductivity material. Reproduced with permission from reference. ${ }^{23,52)}$

to the $B 2 / b$ space group and monoclinic system. ${ }^{24,46,53)}$ $\mathrm{Yb}_{2} \mathrm{SiO}_{5}$ also has the merits of no phase transformation, high-temperature stability, ${ }^{54)}$ excellent corrosion resistance, ${ }^{55)}$ low thermal conductivity (theoretical lattice thermal conductivity: $0.8 \mathrm{~W} /(\mathrm{m} \cdot \mathrm{K})$, experimental thermal conductivity: $1.3 \mathrm{~W} /(\mathrm{m} \cdot \mathrm{K})$ at $1000^{\circ} \mathrm{C}$, as shown in Fig. 3$),{ }^{24)}$ low shear deformation resistance, and good machinability. ${ }^{53)}$ Therefore, it is suitable for use as the matrix material of new-generation porous ceramics.

\subsection{Crystal structure and properties of $\gamma-\mathrm{RE}_{2} \mathrm{Si}_{2} \mathrm{O}_{7}$}

As the typical rare earth disilicate, $\mathrm{Y}_{2} \mathrm{Si}_{2} \mathrm{O}_{7}$ is a promising refractory ceramic. There are six polymorphs of $\mathrm{Y}_{2} \mathrm{Si}_{2} \mathrm{O}_{7}$ (y, $\alpha, \beta, \gamma, \delta$, and possibly z). ${ }^{36,56)}$ Of these, $\gamma-\mathrm{Y}_{2} \mathrm{Si}_{2} \mathrm{O}_{7}$ is stable at both room and high temperatures, with the $\gamma$ phase existing from room temperature to $1535^{\circ} \mathrm{C}: \alpha \stackrel{1250 \pm 10^{\circ} \mathrm{C}}{\longrightarrow} \beta \stackrel{1445 \pm 10^{\circ} \mathrm{C}}{\longrightarrow}$ $\gamma \stackrel{1535 \pm 10^{\circ} \mathrm{C}}{\longrightarrow} \delta \cdot{ }^{57)}$ Hence, the investigations on $\mathrm{Y}_{2} \mathrm{Si}_{2} \mathrm{O}_{7}$ mostly focus on $\gamma-\mathrm{Y}_{2} \mathrm{Si}_{2} \mathrm{O}_{7}$. The crystal structure of $\gamma-\mathrm{Y}_{2} \mathrm{Si}_{2} \mathrm{O}_{7}$ is illus-

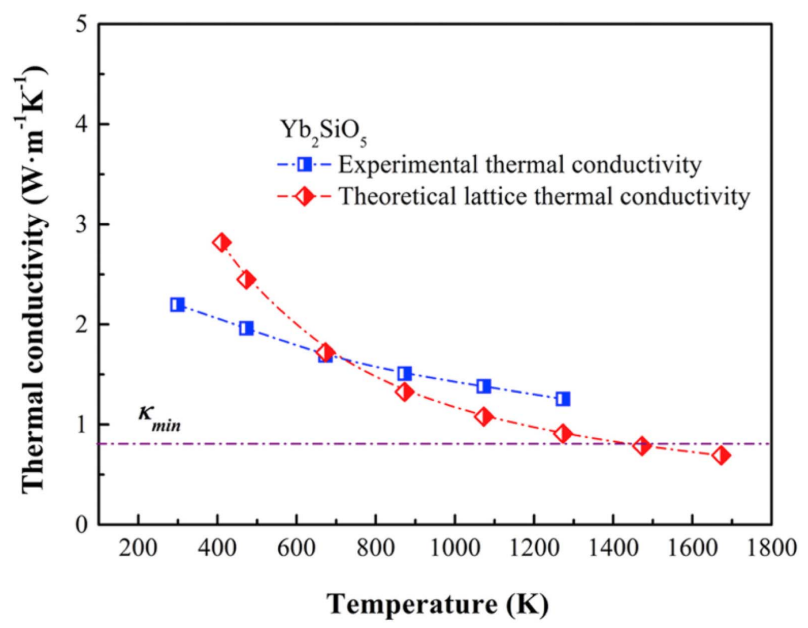

Fig. 3. Experimental, theoretical, and minimum lattice thermal conductivities of $\mathrm{Yb}_{2} \mathrm{SiO}_{5}$. Reproduced with permission from reference. ${ }^{24)}$ 


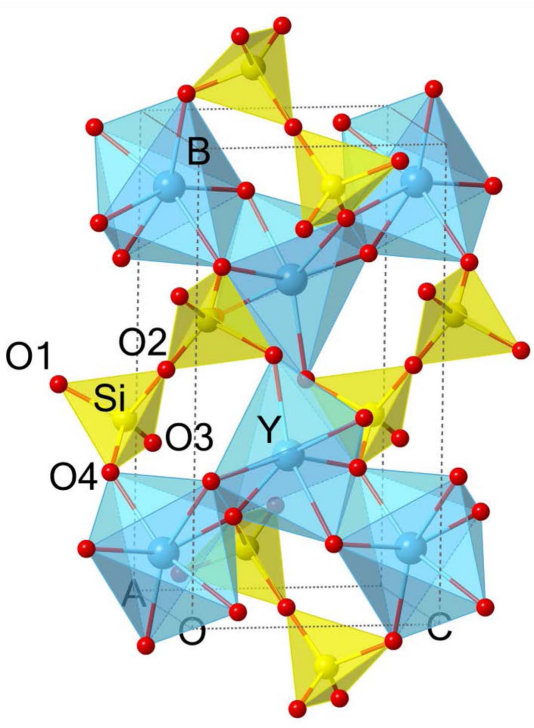

Fig. 4. Crystal structure of $\gamma-\mathrm{Y}_{2} \mathrm{Si}_{2} \mathrm{O}_{7}$. Reproduced with permission from reference. ${ }^{45}$

trated in Fig. 4. $\gamma-\mathrm{Y}_{2} \mathrm{Si}_{2} \mathrm{O}_{7}$ crystallizes in a monoclinic lattice with $P 2_{1} / c$ space group. It has 22 atoms (two formulas) per unit cell, and there are one $\mathrm{Y}$, one $\mathrm{Si}$, and four $\mathrm{O}$ sites. The $\mathrm{Si}$ is fourfold coordinated to the $\mathrm{O}$ atoms in a distorted tetrahedral environment. Two adjacent $\mathrm{SiO}_{4}$ tetrahedra share one $\mathrm{O}$ at the corner and form the $\mathrm{Si}_{2} \mathrm{O}_{7}$ pyrosilicate structure having a linear $\mathrm{Si}-\mathrm{O}-\mathrm{Si}$ bridge. $\mathrm{Y}$ is surrounded by six $\mathrm{O}$ atoms and forms $\mathrm{YO}_{6}$ octahedra. ${ }^{45,58)}$

$\gamma-\mathrm{Y}_{2} \mathrm{Si}_{2} \mathrm{O}_{7}$ is attractive owing to its outstanding properties, including high melting point $\left(1775^{\circ} \mathrm{C}\right)$, low linear thermal expansion coefficient $\left(\sim 3.9 \times 10^{-6} \mathrm{~K}^{-1}, 25-1400^{\circ} \mathrm{C}\right)$, good thermal shock resistance $\left(\Delta T_{\mathrm{c}}=300^{\circ} \mathrm{C}\right)$, and good machinability. ${ }^{21,22,59)}$ Moreover, $\gamma-\mathrm{Y}_{2} \mathrm{Si}_{2} \mathrm{O}_{7}$ is very stable in high-pressure steam at elevated temperatures. It implies that $\gamma$ $\mathrm{Y}_{2} \mathrm{Si}_{2} \mathrm{O}_{7}$ has high chemical and thermal stability, for example, it exhibits good hot corrosion resistance against molten $\mathrm{Na}_{2} \mathrm{SO}_{4}$ (the corrosion scales measured were less than 40 $\mu \mathrm{m}$ at $850-1000^{\circ} \mathrm{C}$ for $20 \mathrm{~h}$, in Fig. 5) and $\mathrm{Na}_{2} \mathrm{CO}_{3}$ salts (the corrosion scales measured were less than $90 \mu \mathrm{m}$ at 850 $1000^{\circ} \mathrm{C}$ for $\left.20 \mathrm{~h}\right){ }^{60,61)}$ Particularly, it exhibits low thermal conductivity $\left(<2 \mathrm{~W} /(\mathrm{m} \cdot \mathrm{K}),>1000^{\circ} \mathrm{C}\right){ }^{22,62)}$ Such a refractory ceramic with low thermal conductivity and good corrosion resistance offers great promise from an application perspective of thermal insulator and could even be used in hightemperature and extreme chemical environments.

Table 1 lists the properties of $\mathrm{X}_{2}-\mathrm{Y}_{2} \mathrm{SiO}_{5}, \mathrm{Yb}_{2} \mathrm{SiO}_{5}$, and $\gamma$ -
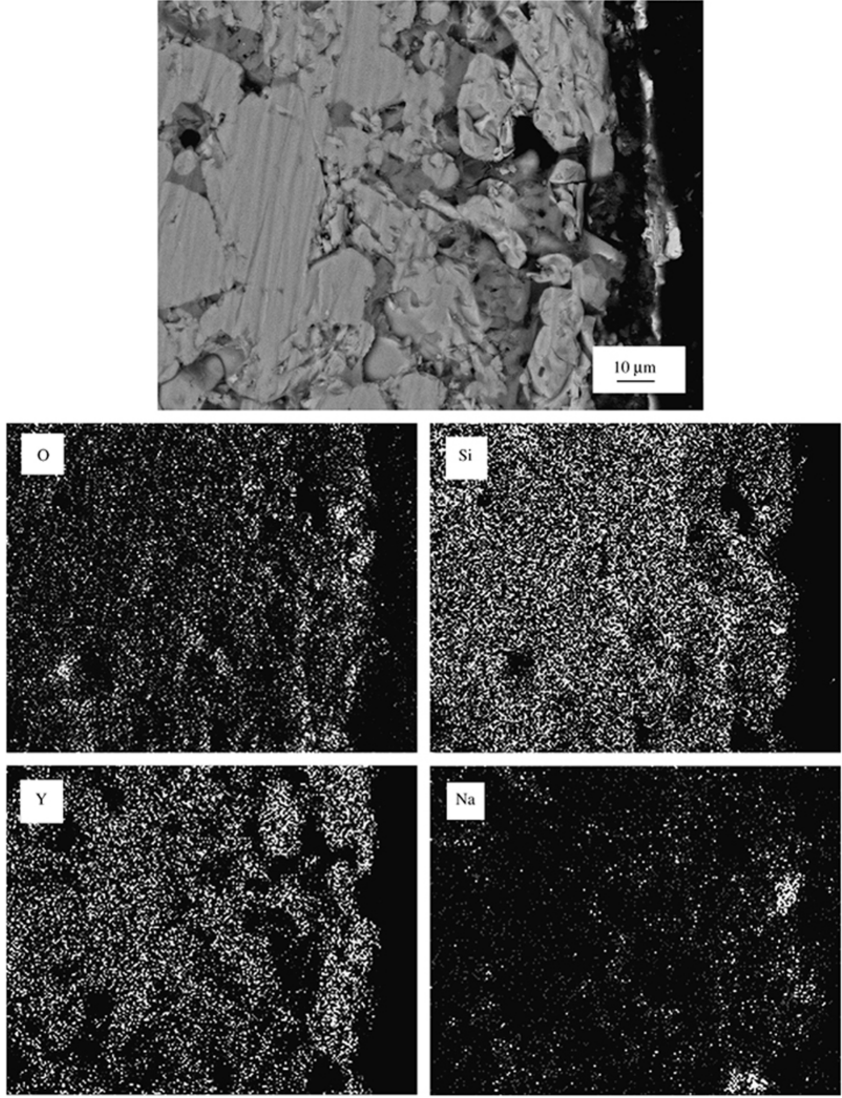

Fig. 5. Cross-sectional micrograph (top) and the corresponding elemental distribution maps of $\gamma-\mathrm{Y}_{2} \mathrm{Si}_{2} \mathrm{O}_{7}$ after hot corrosion at $1000^{\circ} \mathrm{C}$. Reproduced with permission from reference. ${ }^{60)}$

$\mathrm{Y}_{2} \mathrm{Si}_{2} \mathrm{O}_{7}$ ceramics. It can be seen that the advantages of the rare earth silicates used as the matrix of porous thermal insulation materials are their high melting point, low thermal conductivity, phase stability, good thermal and chemical stability, and good corrosion resistance. Therefore, when they are fabricated as porous ceramics, these porous rare earth silicate ceramics would exhibit extraordinary performances even under high temperatures and in extreme environments.

Besides, rare earth silicates can be fabricated in the form of solid solutions that also display good properties, which can obviously reduce the thermal conductivity of the initiating pure material $\left(\mathrm{Y}_{3-\mathrm{x}} \mathrm{Er}_{\mathrm{x}} \mathrm{Al}_{5} \mathrm{O}_{12}, \quad\left(\mathrm{Gd}_{1-\mathrm{x}} \mathrm{Yb}_{\mathrm{x}}\right)_{2} \mathrm{Zr}_{2} \mathrm{O}_{7}\right.$, and $\left.\left(\mathrm{Y}_{\mathrm{x}} \mathrm{Yb}_{1-\mathrm{x}}\right)_{2} \mathrm{SiO}_{5}\right)^{46,63,64)}$ Similarly, our latest study finds that the thermal conductivity of $\gamma-\left(\mathrm{Y}_{1-\mathrm{x}} \mathrm{Ho}_{\mathrm{x}}\right)_{2} \mathrm{Si}_{2} \mathrm{O}_{7}$ solid solution is

Table 1. Properties of Representative Rare Earth Silicates

\begin{tabular}{cccccc}
\hline Compound & $\begin{array}{c}\text { Melting point } \\
\left({ }^{\circ} \mathrm{C}\right)\end{array}$ & $\begin{array}{c}\text { Thermal conductivity } \\
(\mathrm{W} /(\mathrm{m} \cdot \mathrm{K}))\end{array}$ & $\begin{array}{c}\text { Phase-stability } \\
\text { interval }\end{array}$ & $\begin{array}{c}\text { Chemical and } \\
\text { thermal stability }\end{array}$ & $\begin{array}{c}\text { Corrosion } \\
\text { resistance }\end{array}$ \\
\hline $\mathrm{X} 2-\mathrm{Y}_{2} \mathrm{SiO}_{5}$ & 1950 & $<1.34\left(>900^{\circ} \mathrm{C}\right)$ & R.T.-melting point & high & high \\
$\mathrm{Yb}_{2} \mathrm{SiO}_{5}$ & 1950 & $<1.3\left(>1000^{\circ} \mathrm{C}\right)$ & R.T.-melting point & high \\
$\gamma-\mathrm{Y}_{2} \mathrm{Si}_{2} \mathrm{O}_{7}$ & 1775 & $<2\left(>1000^{\circ} \mathrm{C}\right)$ & R.T.- $1535^{\circ} \mathrm{C}$ & high & high \\
\hline
\end{tabular}

R.T. is room temperature. 

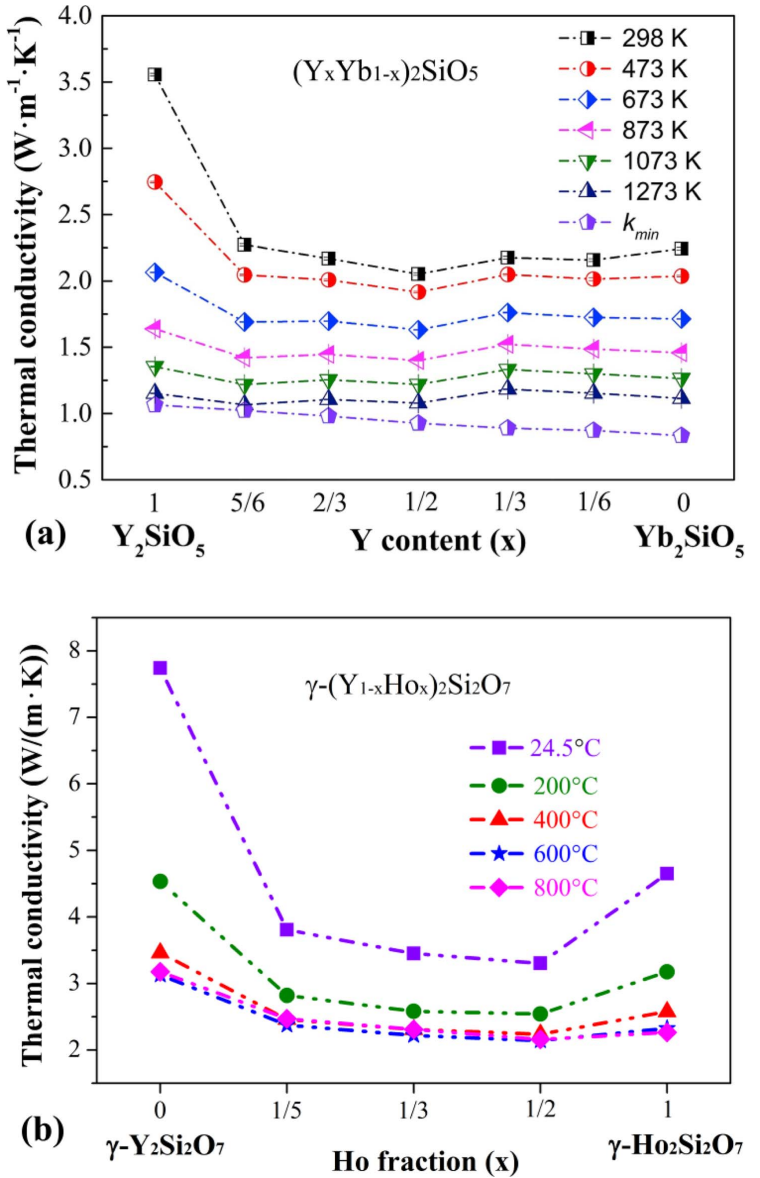

Fig. 6. Thermal conductivities of $\left(\mathrm{Y}_{\mathrm{x}} \mathrm{Yb}_{1-\mathrm{x}}\right)_{2} \mathrm{SiO}_{5}$ (Reproduced with permission from reference. $\left.{ }^{46}\right)$ and $\gamma-\left(\mathrm{Y}_{1-\mathrm{x}} \mathrm{Ho}_{\mathrm{x}}\right)_{2} \mathrm{Si}_{2} \mathrm{O}_{7}$ at different temperatures.

markedly lower than those of $\gamma-\mathrm{Y}_{2} \mathrm{Si}_{2} \mathrm{O}_{7}$ and $\gamma-\mathrm{Ho}_{2} \mathrm{Si}_{2} \mathrm{O}_{7}$, as indicated in Fig. 6. Furthermore, preparing a solid solution is a conventional and effective method to enhance the strength of ceramic materials. ${ }^{65-67)}$ Therefore, the fabrication of porous rare earth solid solution ceramics would result in excellent thermal insulation materials, which is unexpected and surprising.

\section{Preparation, Microstructure, and Properties of Porous RE-Si-O Ceramics}

\subsection{Porous $\mathrm{RE}_{2} \mathrm{SiO}_{5}$ ceramics}

At present, the fabrication and investigations on porous $\mathrm{RE}_{2} \mathrm{SiO}_{5}$ ceramic have mostly focused on porous $\mathrm{Y}_{2} \mathrm{SiO}_{5}$ ceramic, ${ }^{25-28,37-39,68)}$ as well as a few other studies on compound porous $\mathrm{Y}_{2} \mathrm{SiO}_{5}$ ceramic ${ }^{69,70)}$ and porous $\mathrm{Yb}_{2} \mathrm{SiO}_{5}$ ceramic. ${ }^{41,42)}$ As far as the porous $\mathrm{Y}_{2} \mathrm{SiO}_{5}$ ceramic is concerned, there exist several methods to prepare such materials, including TBA-based freeze casting (where TBA refers to tert-butyl alcohol), TBA-based gel-casting, water-based freeze casting, in-situ foam-gelcasting, pore-forming agent, and in-situ foam-gelcasting-freeze drying. Each of the methods can be used to obtain porous ceramics with different pore sizes, microstructures, and properties. From another perspective, these research studies can be divided into two broad categories: direct sintering ${ }^{25-27,37,38)}$ and in-situ reaction sintering, ${ }^{28,39,68)}$ i.e., using $\mathrm{Y}_{2} \mathrm{SiO}_{5}$ powder as the raw material for direct sintering and $\mathrm{Y}_{2} \mathrm{O}_{3}$ and $\mathrm{SiO}_{2}$ powders as the raw materials for in-situ reaction sintering. Moreover, to realize better thermal insulators, the compound porous $\mathrm{Y}_{2} \mathrm{SiO}_{5}$ ceramic was fabricated by recombining other materials, such as silica aerogel-impregnated porous $\mathrm{Y}_{2} \mathrm{SiO}_{5}$ ceramic $^{69)}$ and $\mathrm{ZrO}_{2}$ fiber-reinforced porous $\mathrm{Y}_{2} \mathrm{SiO}_{5}$ ceramic. $^{70)}$ Besides, the water-based freeze casting method was also employed to prepare porous $\mathrm{Yb}_{2} \mathrm{SiO}_{5}$ ceramic. ${ }^{41,42)}$

\subsubsection{Porous $\mathrm{Y}_{2} \mathrm{SiO}_{5}$ ceramic}

3.1.1.1. TBA-based freeze casting method

Li et al. fabricated porous rare earth silicate ceramics, and the new-type porous $\mathrm{Y}_{2} \mathrm{SiO}_{5}$ ceramic emerged in 2012. ${ }^{25)}$ TBA-based freeze casting method was used and porous $\mathrm{Y}_{2} \mathrm{SiO}_{5}$ with an oriented pore structure was obtained. Fig. 7 shows the microstructures of the porous $\mathrm{Y}_{2} \mathrm{SiO}_{5}$ ceramic prepared by the TBA-based freeze casting method. It is interesting to note that the porous $\mathrm{Y}_{2} \mathrm{SiO}_{5}$ sample has a uniform pore size distribution and the well aligned pores grow with a preferential orientation, which is parallel to the freezing direction. The regular and uniform pores are formed because the TBA ice crystal grows with a preferential orientation during the freezing process and TBA normally forms
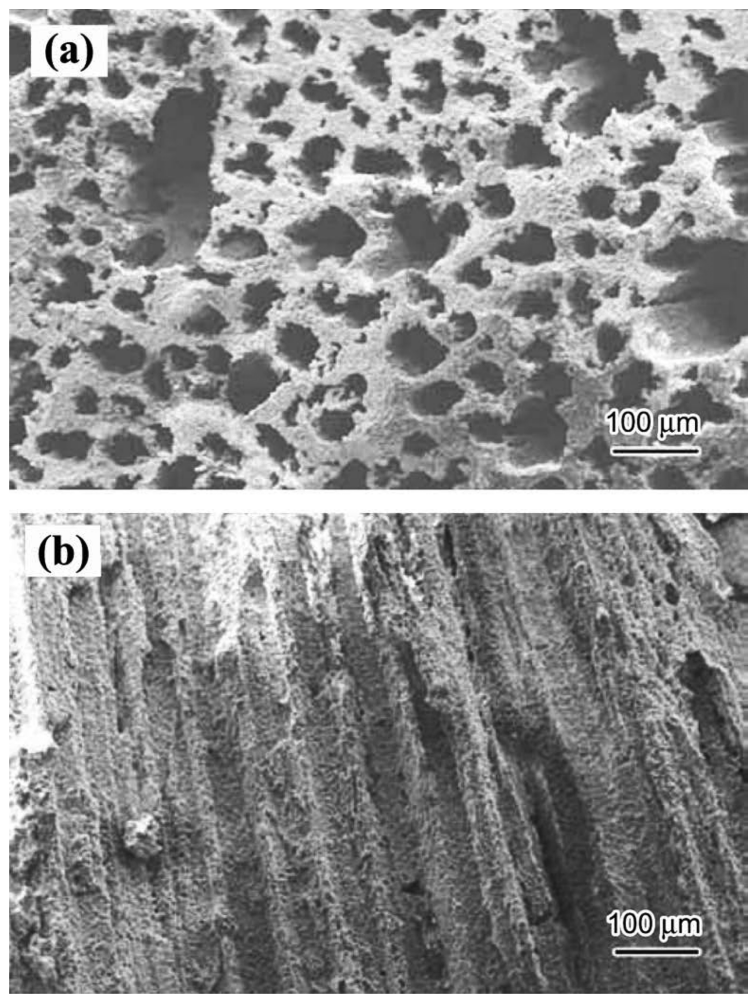

Fig. 7. SEM images of porous $\mathrm{Y}_{2} \mathrm{SiO}_{5}$ ceramic prepared (a) perpendicular and (b) parallel to the freezing direction by TBA-based freeze casting method. Reproduced with permission from reference. ${ }^{25)}$ 

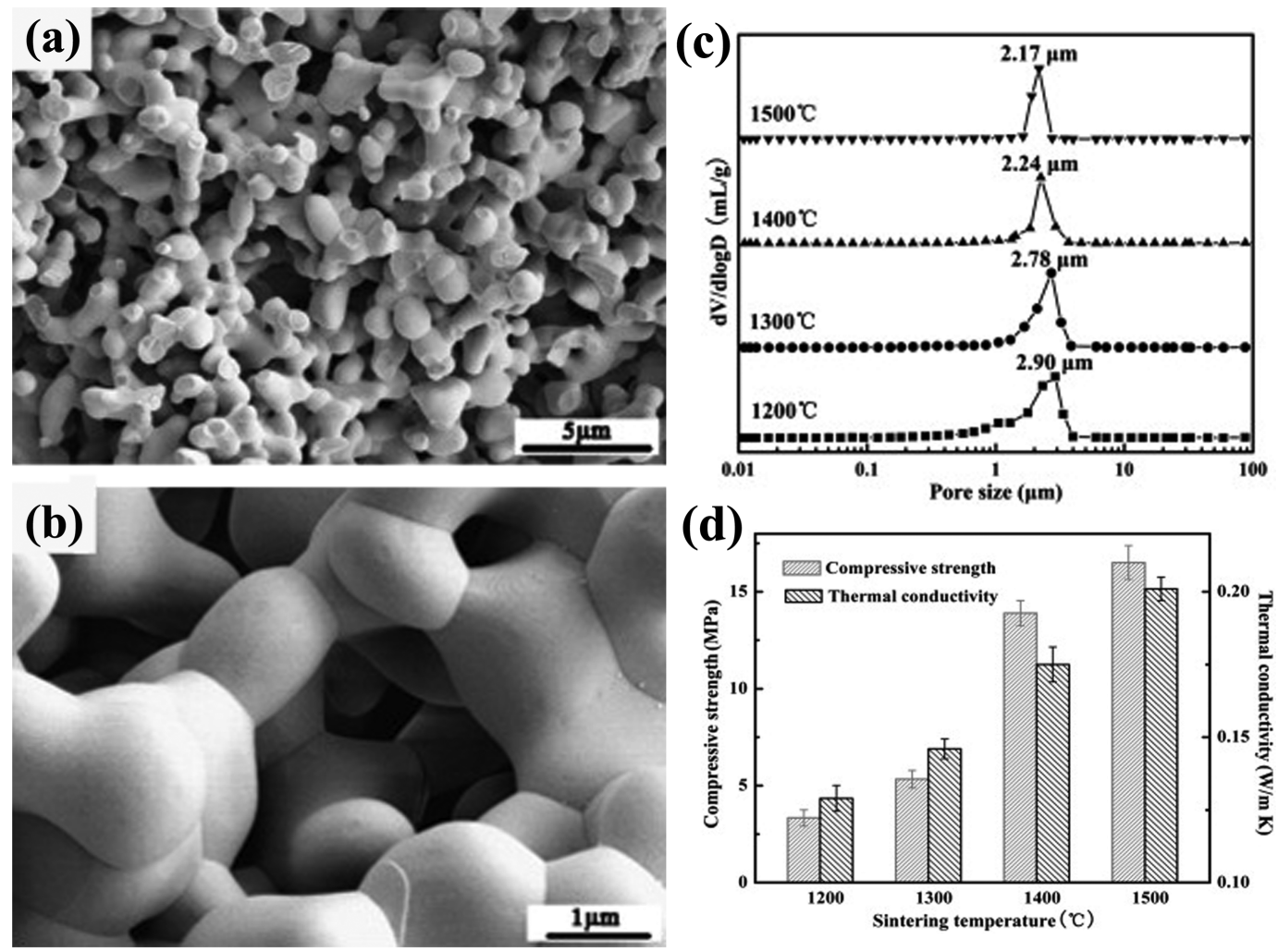

Fig. 8. Microstructures and properties of porous $\mathrm{Y}_{2} \mathrm{SiO}_{5}$ ceramic prepared by TBA-based gel-casting method: (a) microstructure of a sample sintered at $1400^{\circ} \mathrm{C}$, (b) interconnected 3D pore structure, (c) pore size distribution and (d) strength and thermal conductivity of porous samples sintered at $1200-1500^{\circ} \mathrm{C}$. Reproduced with permission from reference. ${ }^{26}$ )

long, straight ice prisms without any branches. ${ }^{71)}$

From Fig. 7(a), it is also observed that the pore size resulting from the TBA freezing ranges from $14 \mu \mathrm{m}$ to $132 \mu \mathrm{m}$, with the mean being about $40 \mu \mathrm{m}$. The pore size and porosity of the porous sample could be adjusted by the solid content of the slurry in the case of the TBA-based freeze casting method. Thus, controlled preparation could be realized. Surprisingly, the thermal conductivity of porous $\mathrm{Y}_{2} \mathrm{SiO}_{5}$ is as low as $0.05 \mathrm{~W} /(\mathrm{m} \cdot \mathrm{K})$, when the porosity is $57 \%$. It indicates that the porous $\mathrm{Y}_{2} \mathrm{SiO}_{5}$ ceramic displays excellent heatshielding performance and would be promising as a thermal insulation material.

\subsubsection{TBA-based gel-casting method}

Hou et al. used TBA-based gel-casting method to fabricate porous $\mathrm{Y}_{2} \mathrm{SiO}_{5} \cdot{ }^{26)}$ The as-prepared porous sample exhibits an isotropic interconnected 3D pore structure, as shown in Fig. 8. The pore size distribution is small and even, as is the distribution of the ceramic particles of $\mathrm{Y}_{2} \mathrm{SiO}_{5}$. Quantitatively, the mean pore size varies from $2.90 \mu \mathrm{m}$ to $2.17 \mu \mathrm{m}$ when the sintering temperature increases from $1200^{\circ} \mathrm{C}$ to $1500^{\circ} \mathrm{C}$ (Fig. 8(c)). As can be seen, TBA-based gel-casting method is an easy way to obtain a narrow and uniform pore distribution (mostly $<5 \mu \mathrm{m}) .^{72-74)}$ More importantly, even, small pores $(1-5 \mu \mathrm{m})$ are conducive to preparing a porous ceramic with low thermal conductivity and high strength, according to Mie theory ${ }^{75-77)}$ and Gibson \& Ashby theory. ${ }^{78,79)}$ As a result, the as-prepared porous $\mathrm{Y}_{2} \mathrm{SiO}_{5}$ ceramic also has the advantages of low thermal conductivity $(0.13-0.20 \mathrm{~W} /(\mathrm{m} \cdot \mathrm{K})$ ) and relatively high strength $(3.34-16.51 \mathrm{MPa})$, with the porosity of $58 \%-67 \%$, as presented in Fig. $8(\mathrm{~d})$.

\subsubsection{Water-based freeze casting method}

Zhang et al. employed water-based freeze casting technique to fabricate porous $\mathrm{Y}_{2} \mathrm{SiO}_{5}{ }^{27,37)}$ The characteristics of the water-based freeze casting method are that the as-prepared porous material contains long straight channels generated by the freezing of water and the porous skeleton (Fig. 9(a) and (b)). Meanwhile, the pore structures of the samples are uniformly distributed and interconnected. Furthermore, the properties of the porous samples are very good, such as high porosity $(71 \%)$, low thermal conductivity $(0.07 \mathrm{~W} /$ $(\mathrm{m} \cdot \mathrm{K})$ ), and low dielectric constant (1.89) (Fig. 9(c) and (d)). The low thermal conductivity of porous $\mathrm{Y}_{2} \mathrm{SiO}_{5}$ is useful for high-temperature insulation applications.

It should be mentioned that, although both TBA and water could be used as the dispersion medium, there are some differences. Table 2 lists some of the physical properties of TBA and water. ${ }^{72)}$ From the table, it can be seen that each solvent has its own advantages. The merits of water are that it is convenient, environmentally friendly, and safe. With regard to TBA, it has a low freezing temperature, low surface tension, and good volatility. When different mediums are chosen, different microstructures are obtained. If 

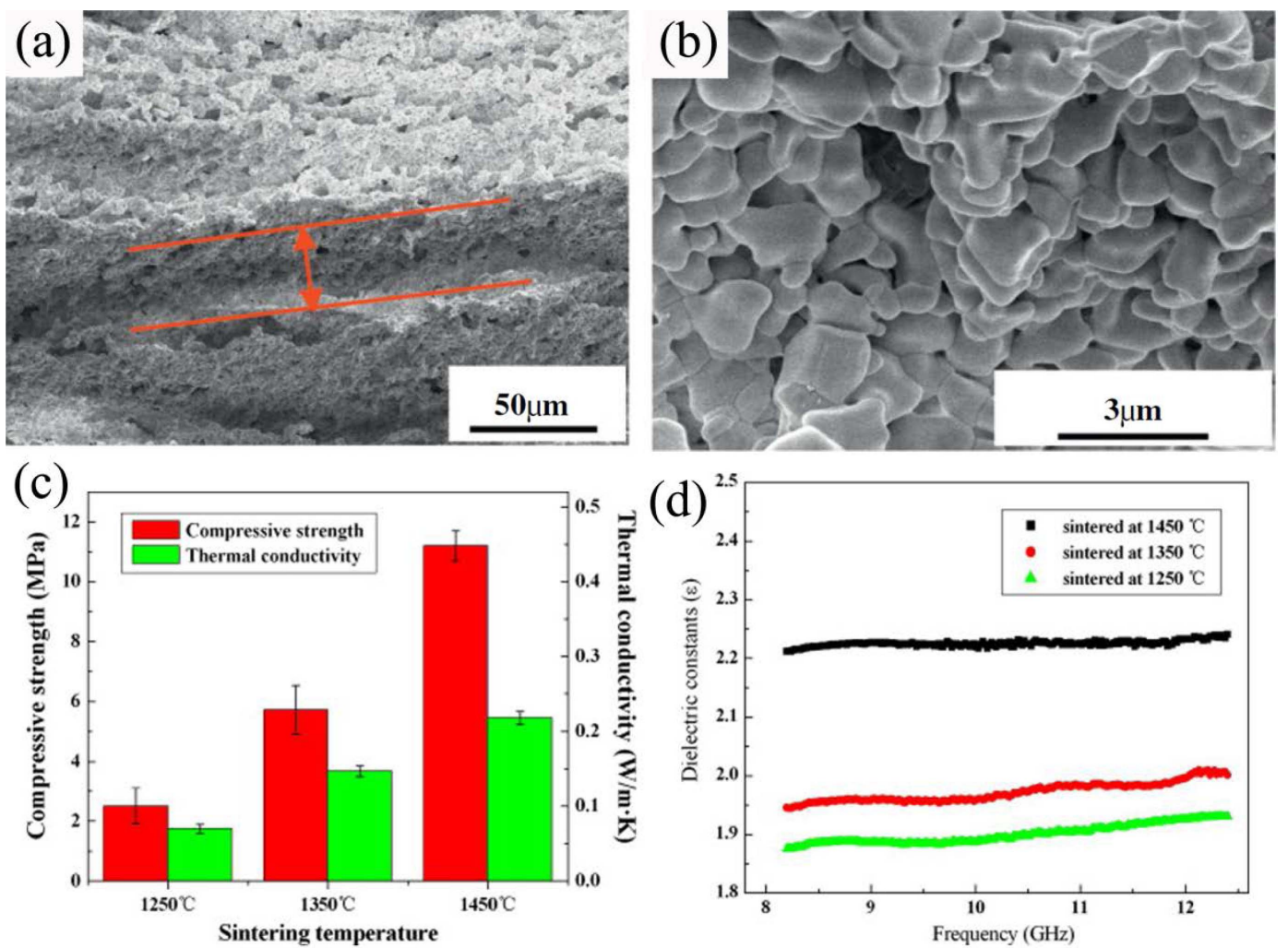

Fig. 9. Microstructures and properties of porous $\mathrm{Y}_{2} \mathrm{SiO}_{5}$ ceramic prepared by water-based freeze casting method: (a) reveals long straight channels, while (b) shows the pore walls; (c) compressive strength and thermal conductivity; and (d) dielectric constant of samples sintered at $1250-1450^{\circ} \mathrm{C}$. Reproduced with permission from reference..$^{27}$

Table 2. Some Physical Properties of Tert-Butyl Alcohol (TBA) and Water. Reproduced with permission from reference ${ }^{71,72)}$

\begin{tabular}{|c|c|c|c|c|c|c|}
\hline Medium & $\begin{array}{l}\text { Liquid density } \\
\qquad(\mathrm{g} / \mathrm{mL})\end{array}$ & $\begin{array}{c}\text { Freezing } \\
\text { temperature }\left({ }^{\circ} \mathrm{C}\right)\end{array}$ & $\begin{array}{c}\text { Saturated vapor } \\
\text { pressure at } 40^{\circ} \mathrm{C}(\mathrm{kPa})\end{array}$ & $\begin{array}{l}\text { Surface tension } \\
\text { at } 40^{\circ} \mathrm{C}(\mathrm{mN} / \mathrm{m})\end{array}$ & $\begin{array}{c}\text { Volume } \\
\text { increase (\%) }\end{array}$ & Toxicity \\
\hline TBA & 0.79 & 25.3 & 6.4 & 15.15 & 2 & low \\
\hline Water & 1 & 0 & 3.4 & 72.10 & 11 & no \\
\hline
\end{tabular}

water is used to make up the slurry, a lamellar pore structure is usually obtained after freeze drying (without gela- tion). ${ }^{80-82)}$ For TBA, it is general to produce an aligned straight prismatic pore-channel structure, due to its freez-
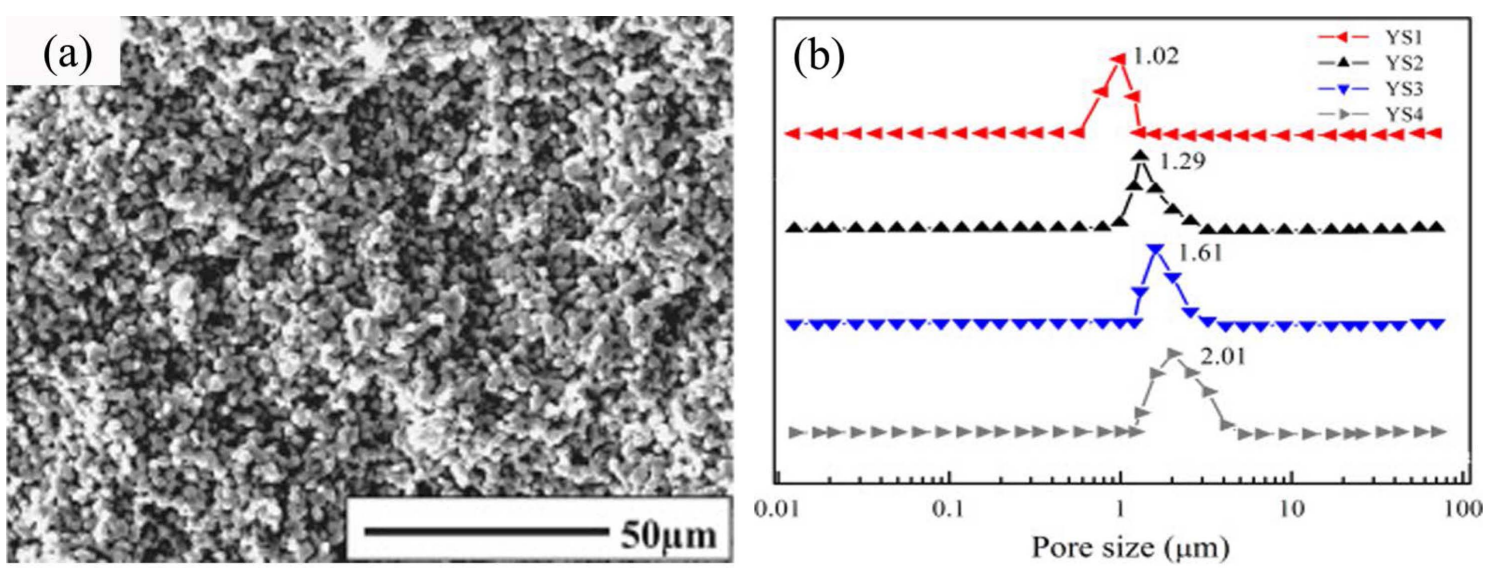

Fig. 10. Porous $\mathrm{Y}_{2} \mathrm{SiO}_{5}$ ceramic prepared by pore-forming agent method: (a) Microstructure of a sample with $40 \mathrm{wt} \%$ starch powder and (b) pore size distributions of samples with 10-40 wt\% starch powders. Reproduced with permission from reference. $^{38)}$ 


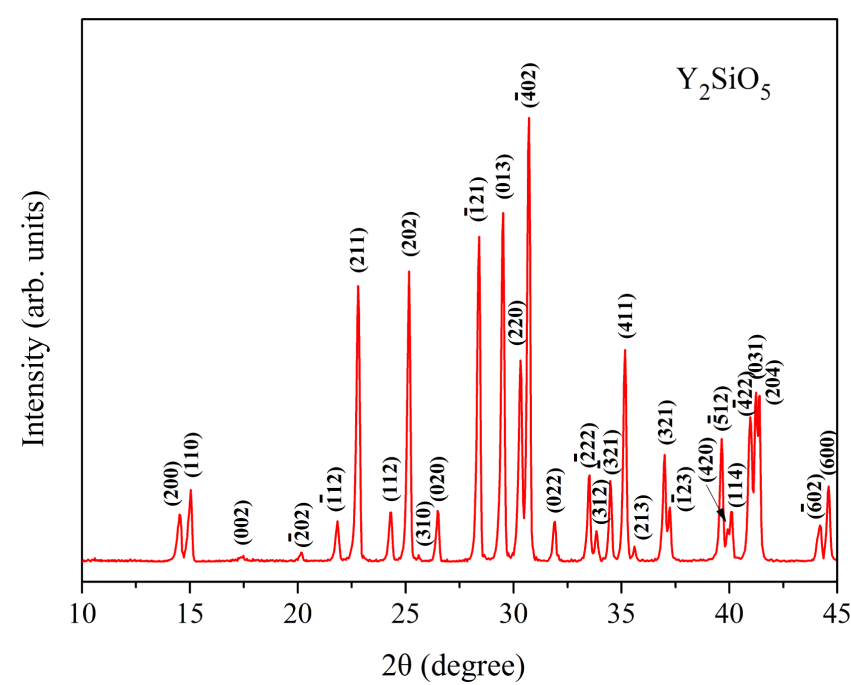

Fig. 11. XRD pattern of pure-phase porous $\mathrm{Y}_{2} \mathrm{SiO}_{5}$ ceramic sintered at $1550^{\circ} \mathrm{C}$ for $3 \mathrm{~h}$ in air by in-situ foamgelcasting method. Reproduced with permission from reference. ${ }^{68)}$

ing. ${ }^{71,83)}$

\subsubsection{Pore-forming agent method}

He et al. adopted the technique of adding a pore-forming material to fabricate porous $\mathrm{Y}_{2} \mathrm{SiO}_{5}{ }^{38)}$ The advantages of this method are its simple process, the controllability of pore shape and size and porosity, and its good body-forming abil- ity, ${ }^{84-86)}$ i.e., the pore shape, pore size, and porosity are controlled by adjusting the category, particle size, and amount of the pore-forming agent added. The as-prepared porous $\mathrm{Y}_{2} \mathrm{SiO}_{5}$ material has a uniform pore and skeleton distribution, narrow pore size distribution (1.02-2.01 $\mu \mathrm{m})$, and low thermal conductivity $(0.81-0.18 \mathrm{~W} /(\mathrm{m} \cdot \mathrm{K}))$, with the porosity being $38.3 \%-70.4 \%$, as indicated in Fig. 10 .

3.1.1.5. In-situ reaction sintering foam-gelcasting method $\mathrm{Y}_{2} \mathrm{SiO}_{5}$ powder served as the raw material in all the abovementioned studies. Wu et al. found a new way to synthesize porous $\mathrm{Y}_{2} \mathrm{SiO}_{5}$ ceramic via in-situ reaction sintering process by using $\mathrm{Y}_{2} \mathrm{O}_{3}$ and $\mathrm{SiO}_{2}$ powders as the starting materials. ${ }^{28,68)}$ Experimental results demonstrate that the in-situ reaction sintering technique could easily result in a single-phase (Fig. 11) porous $\mathrm{Y}_{2} \mathrm{SiO}_{5}$ ceramic with very low sintering shrinkage, quite high porosity, and high strength. ${ }^{28,68)}$ In-situ foam-gelcasting method was employed to prepare a porous sample. Compared with the direct foamgelcasting method that uses $\mathrm{Y}_{2} \mathrm{SiO}_{5}$ powder as the raw material, the porous $\mathrm{Y}_{2} \mathrm{SiO}_{5}$ sample fabricated by in-situ foam-gelcasting has multiple pore structures, including large $(30-400 \mu \mathrm{m})$ and small pores $(0.2-1 \mu \mathrm{m})$ in the cell walls (Fig. 12) ${ }^{68)}$ Regarding the formation of the pores, the large pores are generated by the foaming process, whereas the small pores can be mainly attributed to the in-situ reaction partial sintering. ${ }^{28,40)}$

It is worth noting that the skeleton gets denser with increasing sintering temperatures for the direct sintering
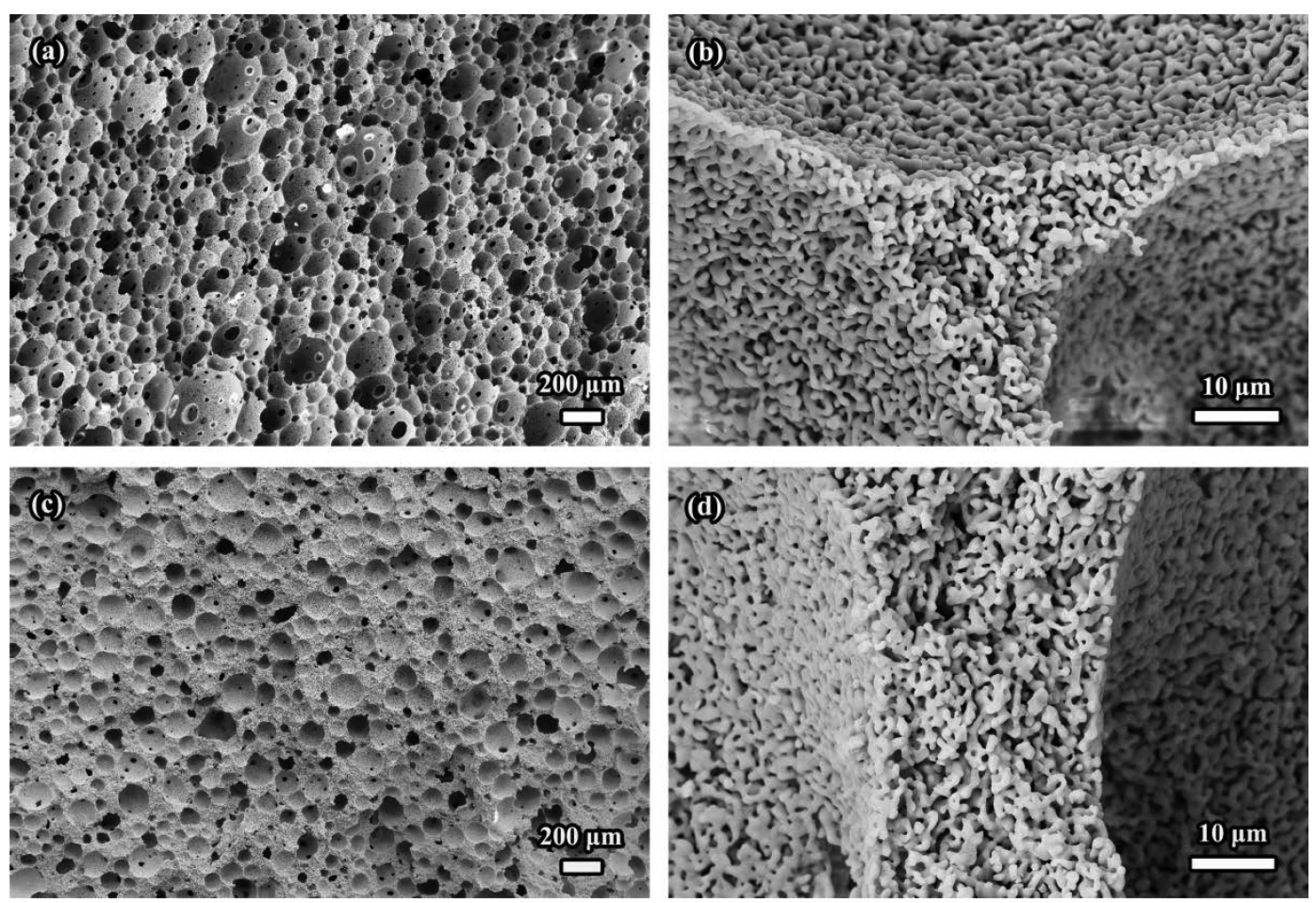

Fig. 12. SEM images of porous $\mathrm{Y}_{2} \mathrm{SiO}_{5}$ prepared by in-situ foam-gelcasting method with different porosities and interconnected porous structures: (a) and (b) large pores and small pores with porosity of $88.4 \%$, and (c) and (d) large pores and small pores with porosity of $72.4 \%$. Reproduced with permission from reference. ${ }^{68}$ ) 

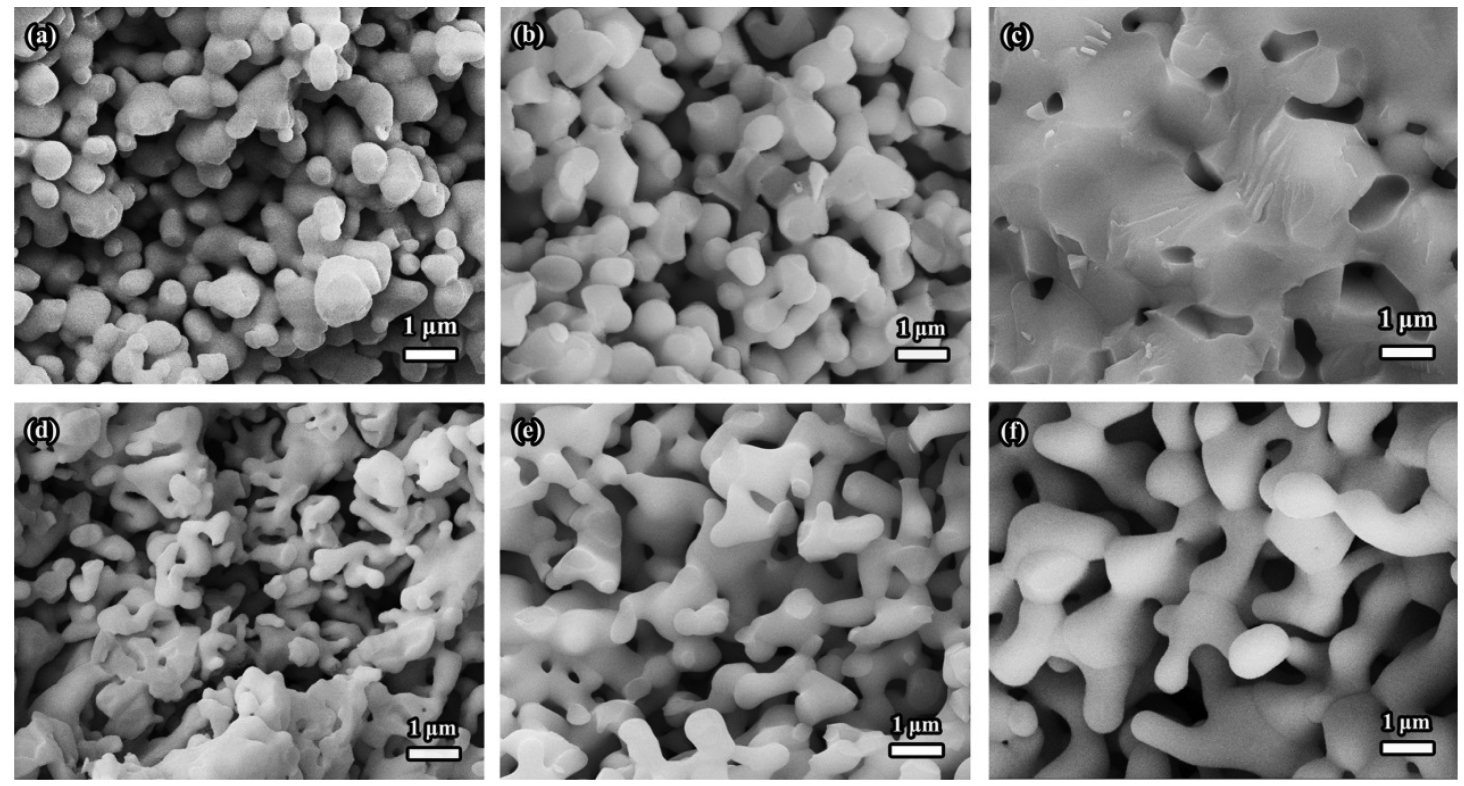

Fig. 13. SEM images of the morphology of the skeleton of porous $\mathrm{Y}_{2} \mathrm{SiO}_{5}$ synthesized through two sintering methods at different temperatures: direct sintering, (a) $1350^{\circ} \mathrm{C}$; (b) $1450^{\circ} \mathrm{C}$; (c) $1550^{\circ} \mathrm{C}$, and in-situ reaction sintering, (d) $1350^{\circ} \mathrm{C}$; (e) $1450^{\circ} \mathrm{C}$; (f) $1550^{\circ} \mathrm{C}$. Reproduced with permission from reference. ${ }^{28)}$

process. However, the skeletons of the samples always maintain uniformly porous structures at elevated temperatures for the in-situ reaction sintering process, as presented in Fig. 13. ${ }^{28)}$ Except for the only difference in the starting powder $\left(\mathrm{Y}_{2} \mathrm{SiO}_{5}\right.$ vs. $\mathrm{Y}_{2} \mathrm{O}_{3}$ and $\left.\mathrm{SiO}_{2}\right)$, the two processes have the same preparation conditions, such as the proportion of
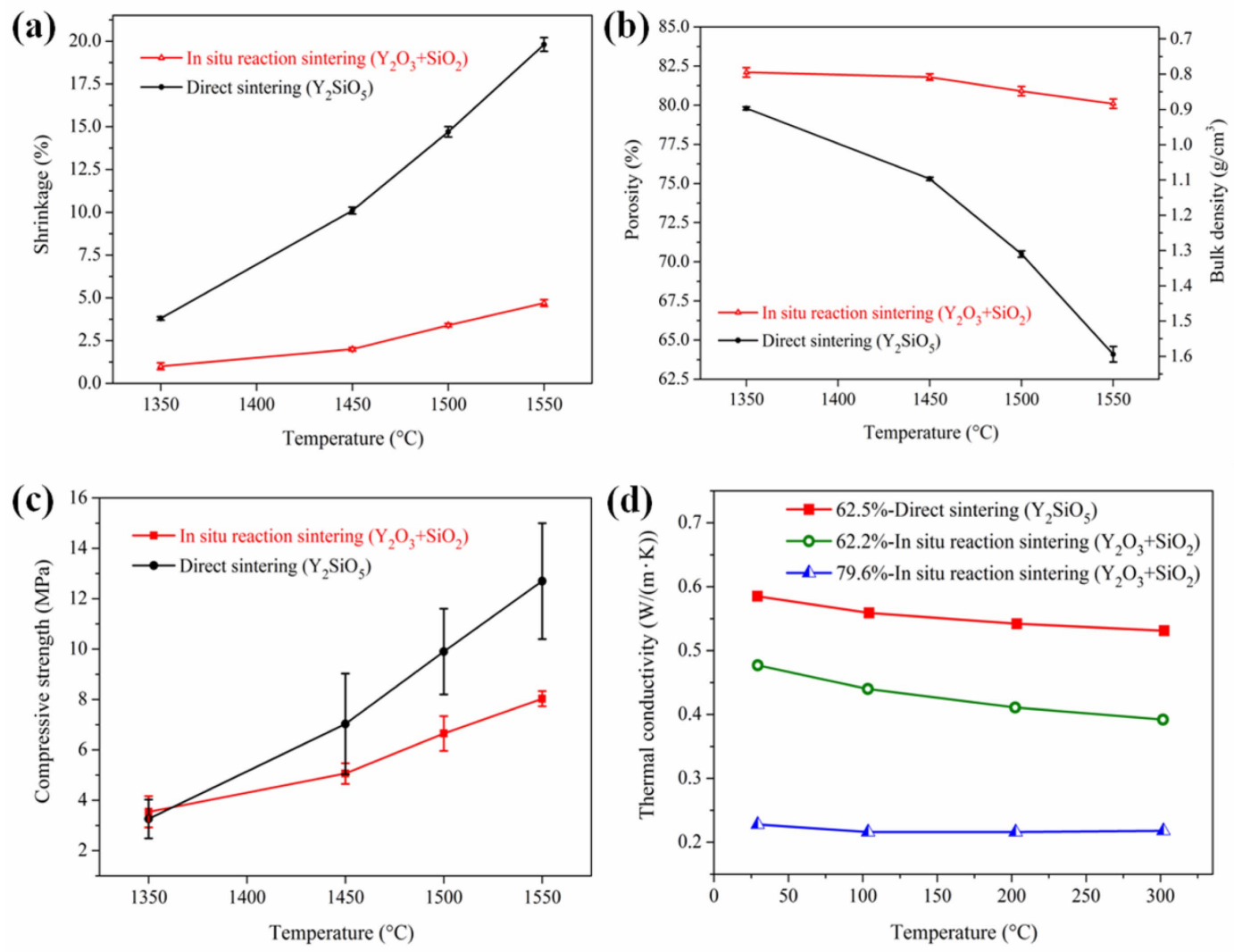

Fig. 14. Effects of (in-situ and direct) sintering methods on the (a) shrinkage, (b) porosity, (c) compressive strength, and (d) thermal conductivity of porous $\mathrm{Y}_{2} \mathrm{SiO}_{5}$ at different sintering temperatures $\left(1350-1550^{\circ} \mathrm{C}\right)$. Reproduced with permission from reference. ${ }^{28)}$ 

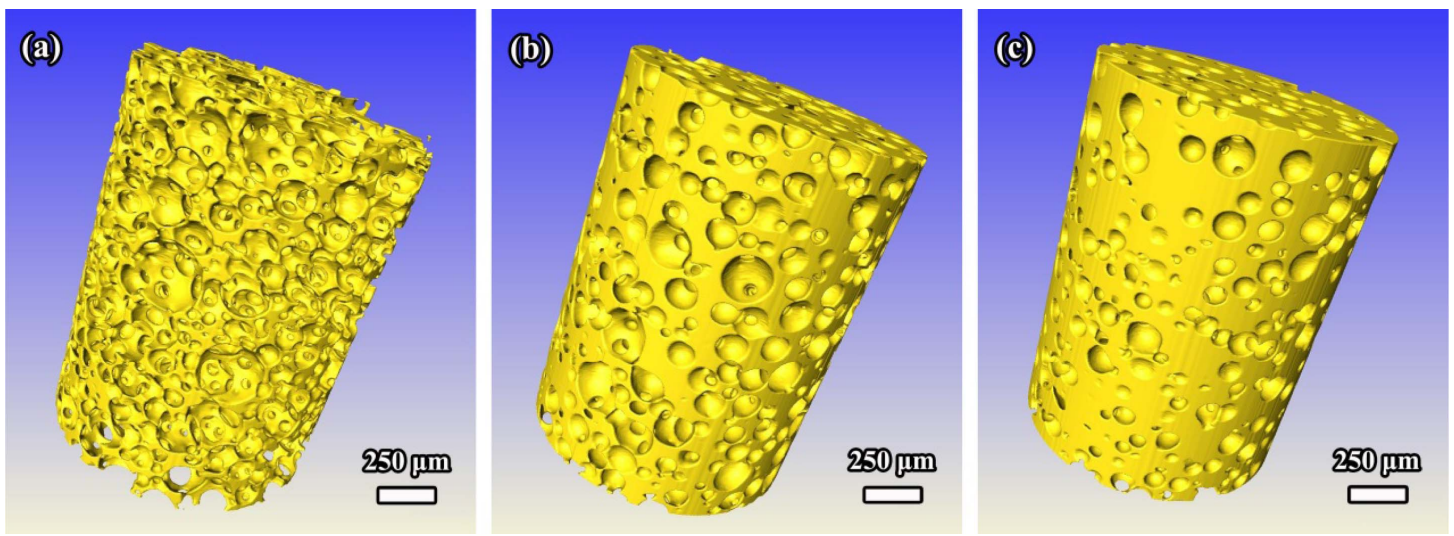

Fig. 15. XRT images of porous $\mathrm{Y}_{2} \mathrm{SiO}_{5}$ ceramics with different porosities: (a) $88.4 \%$, (b) $72.4 \%$, and (c) 60.7\%. Reproduced with permission from reference. ${ }^{68)}$

slurry, foam process, and sintering technology (heating and cooling rates and temperature). The reason for such a phenomenon is that, the main reaction is the rapid sintering of adjacent $\mathrm{Y}_{2} \mathrm{SiO}_{5}$ particles, for the direct sintering process; nevertheless, for the in-situ sintering process, the dominant reaction is the slow molecular diffusion occurring through the contact surfaces of $\mathrm{Y}_{2} \mathrm{O}_{3}$ and $\mathrm{SiO}_{2}$ powders. Perhaps, the primary reaction site of direct sintering is centered in the surface layer of the $\mathrm{Y}_{2} \mathrm{SiO}_{5}$ powder and adjacent particles are bonded together, while the in-situ reaction sintering pervades every part of the starting particle and the interspaces between the adjacent powders are still existed after the reaction. Thus, the direct sintering occurs more easily than the in-situ reaction sintering, and the skeleton becomes denser during direct sintering. However, the formed skeleton is porous for in-situ reaction sintering.

Moreover, the obvious difference in the microstructure could result in a huge difference in the properties, ${ }^{28)}$ as illustrated in Fig. 14. As can be seen, the properties of porous $\mathrm{Y}_{2} \mathrm{SiO}_{5}$ ceramic fabricated by in-situ sintering are superior to those obtained by direct sintering. For example, much lower sintering shrinkage $(1.0 \%-4.7 \%)$, higher porosity (82.1\%-80.1\%), lower density $\left(0.79-0.88 \mathrm{~g} / \mathrm{cm}^{3}\right)$, higher strength $(3.54 \mathrm{MPa}$, porosity $=82.1 \%)$, and lower thermal conductivity $(0.477 \mathrm{~W} /(\mathrm{m} \cdot \mathrm{K})$, porosity $=62.3 \%)$ are observed compared to those (shrinkage: $3.8 \%-19.8 \%$, porosity: 79.8\%-64.1\%, density: $0.90-1.59 \mathrm{~g} / \mathrm{cm}^{3}$, strength: $3.26 \mathrm{MPa}$ (porosity $=79.8 \%$ ), and thermal conductivity: $0.585 \mathrm{~W} /(\mathrm{m} \cdot \mathrm{K})$ (porosity $=62.5 \%)$ ) of the porous ceramic synthesized by the direct sintering method.

As mentioned earlier, the direct sintering occurs more easily and the skeleton is denser, compared to those of insitu reaction sintering. Naturally, when $\mathrm{Y}_{2} \mathrm{SiO}_{5}$ powder is used as the starting material, the sintering linear shrinkage is much higher, especially at high temperatures $\left(>1500^{\circ} \mathrm{C}\right)$. Therefore, a lower shrinkage, a lower density and a higher strength are obtained in the case of in-situ reaction sintering method. It should be noticed that, the compressive strength and thermal conductivity of the samples obtained by in-situ reaction sintering are overmatched those of the porous ceramic prepared from direct sintering, under the condition of similar porosity (Fig. 14(c) and (d)). This indicates that in-situ reaction sintering could produce strong and firm sintering necks, which contribute to the high strength. Meanwhile, in-situ reaction sintering could also form uniform small pores in the skeleton, which is beneficial in restraining heat transport and reducing thermal conductivity. The results show that the in-situ reaction sintering process is an effective method for preparing porous $\mathrm{Y}_{2} \mathrm{SiO}_{5}$ ceramics exhibiting excellent performances.

Additionally, the in-situ foam-gelcasting method was used to prepare porous $\mathrm{Y}_{2} \mathrm{SiO}_{5}$ with different porosities $(60.7 \%$ $88.4 \%$ ) that were controlled by adjusting the raw material ratio. When the porosities are different, the microstructures are also different. A sample with a higher porosity has more large pores and thinner pore walls. On the other hand, a sample with a low porosity contains more small pores and thicker pore walls, as shown in Fig. 15. Corresponding properties are also obtained, including low linear shrinkages of $6.3 \%-4.5 \%$, high compressive strengths of $38.2-0.90 \mathrm{MPa}$, and low thermal conductivities of $0.126-0.513 \mathrm{~W} /(\mathrm{m} \cdot \mathrm{K})$ (porosity: 87.1\%-60.2\%), as shown in Fig. 16. ${ }^{68)}$ Furthermore, porous $\mathrm{Y}_{2} \mathrm{SiO}_{5}$ still exhibits outstanding strengths at high temperatures (the compressive strengths at $1100^{\circ} \mathrm{C}$ and $1300^{\circ} \mathrm{C}$ are $95 \%$ and $80 \%$, respectively, of that at room temperature). The results indicate that porous $\mathrm{Y}_{2} \mathrm{SiO}_{5}$ ceramic prepared by in-situ foam-gelcasting is a potential high-temperature thermal insulation material owing to its light weight, low thermal conductivity, and high strength.

\subsubsection{In-situ foam-gelcasting-freeze drying method}

In the above results, we can see that the highest porosity of porous $\mathrm{Y}_{2} \mathrm{SiO}_{5}$ ceramic reported from most studies is only about $73 \%$. Even when the in-situ foam-gelcasting method is used, the highest porosity realized is $88.4 \%$. It is difficult to obtain higher porosities $(>90 \%)$ for porous $\mathrm{Y}_{2} \mathrm{SiO}_{5}$. The reasons for this are, on one hand, when $\mathrm{Y}_{2} \mathrm{SiO}_{5}$ powder is used as the raw material, serious linear shrinkage (15\%- 


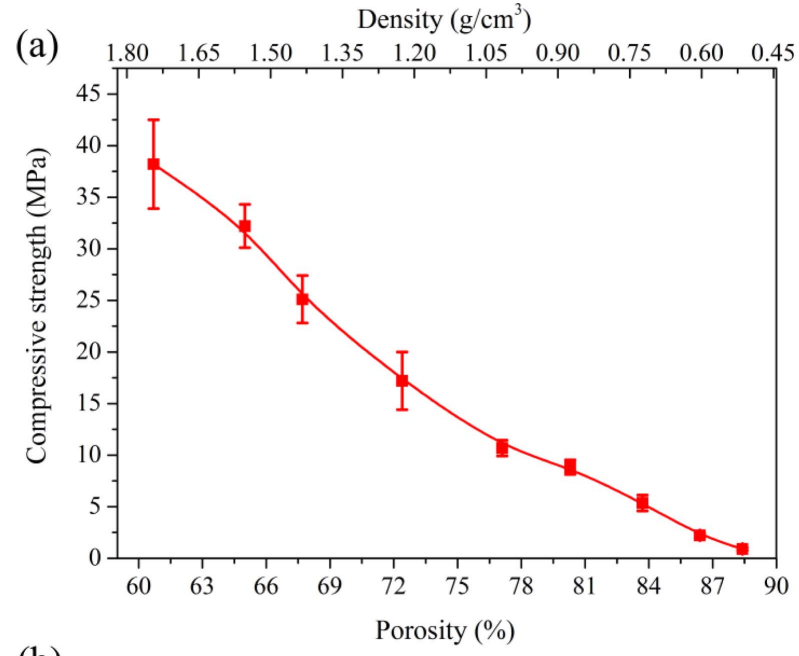

(b)

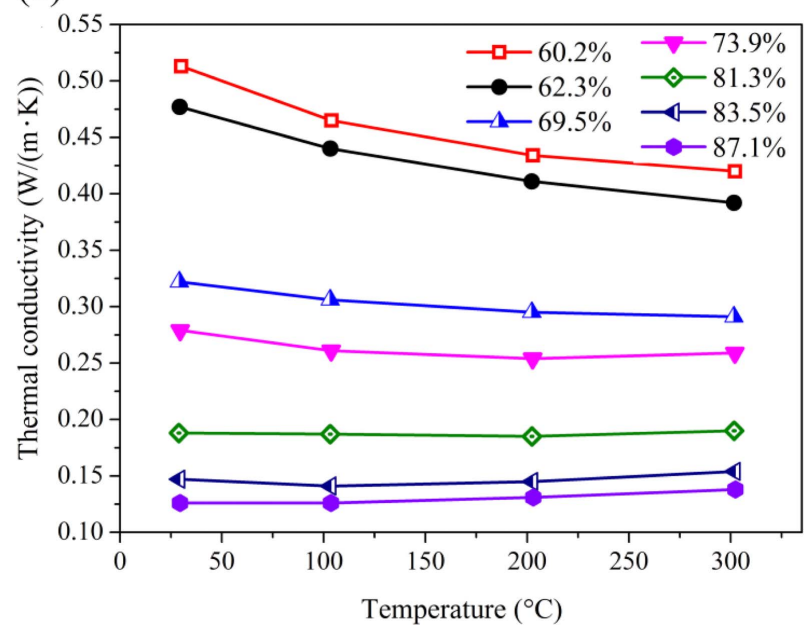

Fig. 16. Effect of porosity on the (a) compressive strength and (b) thermal conductivity of porous $\mathrm{Y}_{2} \mathrm{SiO}_{5}$ ceramic. Reproduced with permission from reference. $^{68)}$

$22 \%$ ) is occurred at high temperatures for TBA-based freeze casting, TBA-based gel-casting, water-based freeze casting, foam-gelcasting (direct sintering), and pore-forming agent methods. ${ }^{25-28,38)}$ Naturally, the large sintering shrinkage significantly reduces the porosity of the porous sample. The root of the problem is the enormous shrinkage occurred during the high-temperature sintering process. On the other hand, as for the in-situ foam-gelcasting method, in order to obtain a high porosity, it is necessary to use a slurry with low solid content ( $<25$ vol.\%) and highly foam the slurry. In this method, the cell wall of the foamed green body is very weak and can be easily deformed and shrunk under a high surface tension because of the gas-liquid interface that forms during the drying process. ${ }^{72,87}$ Thus, the problem is the evident deformation and shrinkage occurred during the drying process.

Therefore, a new technique should be explored for preparing porous $\mathrm{Y}_{2} \mathrm{SiO}_{5}$ ceramics with quite high porosities $(>90 \%)$. Only when a very high porosity is realized can lower density and lower thermal conductivity be obtained for a porous material. Then, the thermal insulator would display excellent heat-shielding performance. Afterwards, in-situ foam-gelcasting-freeze drying method was developed to fabricate porous $\mathrm{Y}_{2} \mathrm{SiO}_{5}$ with higher porosities (>90\%). ${ }^{39}$ In the freeze drying process, the gas-liquid interface is eliminated and the surface tension of water is prevented by the sublimation of ice. ${ }^{88-90)}$ Hence, the phenomena of deformation and shrinkage for a green body are avoided after the freeze drying process, even though slurries with low solid contents (10-20 vol.\%) are used. The advantages of freeze drying and in-situ reaction sintering can be successfully combined together to simultaneously obtain low drying shrinkage $(<1.9 \%)$ and low sintering shrinkage $(5.5 \%-$ $7.7 \%){ }^{39)}$ which contribute to superhigh porosities.

Porous $\mathrm{Y}_{2} \mathrm{SiO}_{5}$ ceramic prepared by in-situ foam-gelcasting-freeze drying technique also displays multiple pore structures (large and small pores), which is similar to the microstructure obtained by the in-situ foam-gelcasting method. Moreover, even though the freeze drying process is utilized, there are no unidirectional pores in the porous sample. It suggests that the freezing of water and the growth of ice crystals have little effects on the microstructure of the porous ceramic, as shown in Fig. 17. For the microstructures of the porous samples fabricated from different solid contents, the same points are that they have similar multiple structures and similar small pore distribution (0.4-3.5 um; Fig. 17(b), (e), and (h)). However, the difference is that the distribution of the large pores is wide (70-500 $\mu \mathrm{m}$, Fig. 17(a)) for the sample with low solid content and high porosity, whereas it is narrow for the sample with a relatively high solid content and low porosity (60$400 \mu \mathrm{m}$ and $45-260 \mu \mathrm{m}$, Fig. $17(\mathrm{~d})$ and $(\mathrm{g}))^{39)}$

In terms of properties, the biggest highlights are the superhigh porosity $(95.8 \%)$, quite low density $\left(0.19 \mathrm{~g} / \mathrm{cm}^{3}\right)$, and extremely low thermal conductivity $(0.054 \mathrm{~W} /(\mathrm{m} \cdot \mathrm{K}))$ obtained through the in-situ foam-gelcasting-freeze drying method. A thermal insulator that is lightweight and has a low thermal conductivity was realized. Besides, the shrinkage is $7.7 \%$ when sintered at the high temperature of $1550^{\circ} \mathrm{C}$ for $3 \mathrm{~h}$, for the solid content of 10 vol.\%. Particularly, the porous $\mathrm{Y}_{2} \mathrm{SiO}_{5}$ ceramic also exhibits excellent thermal stability in the condition of such a high porosity. The shrinkages of the 1st, 2nd, and 3rd cycles (heating from $25^{\circ} \mathrm{C}$ to $1550^{\circ} \mathrm{C}$ and holding for $3 \mathrm{~h}$ in every circulation) are only $1.7 \%, 2.0 \%$, and $1.9 \%$, respectively for the initial sample with the porosity of $93.9 \%{ }^{39)}$ The results suggest that insitu foam-gelcasting-freeze drying method is an effective method to fabricate porous ceramics with ultrahigh porosities and low thermal conductivities.

The contrasts in the properties of porous $\mathrm{Y}_{2} \mathrm{SiO}_{5}$ ceramics obtained by different methods are presented in Table 3 . It can be seen that the pore sizes are small and the pore distributions are narrow for the porous $\mathrm{Y}_{2} \mathrm{SiO}_{5}$ materials prepared by freeze-casting, gel-casting, and pore-forming agent methods. On the other hand, the porous samples fabricated 

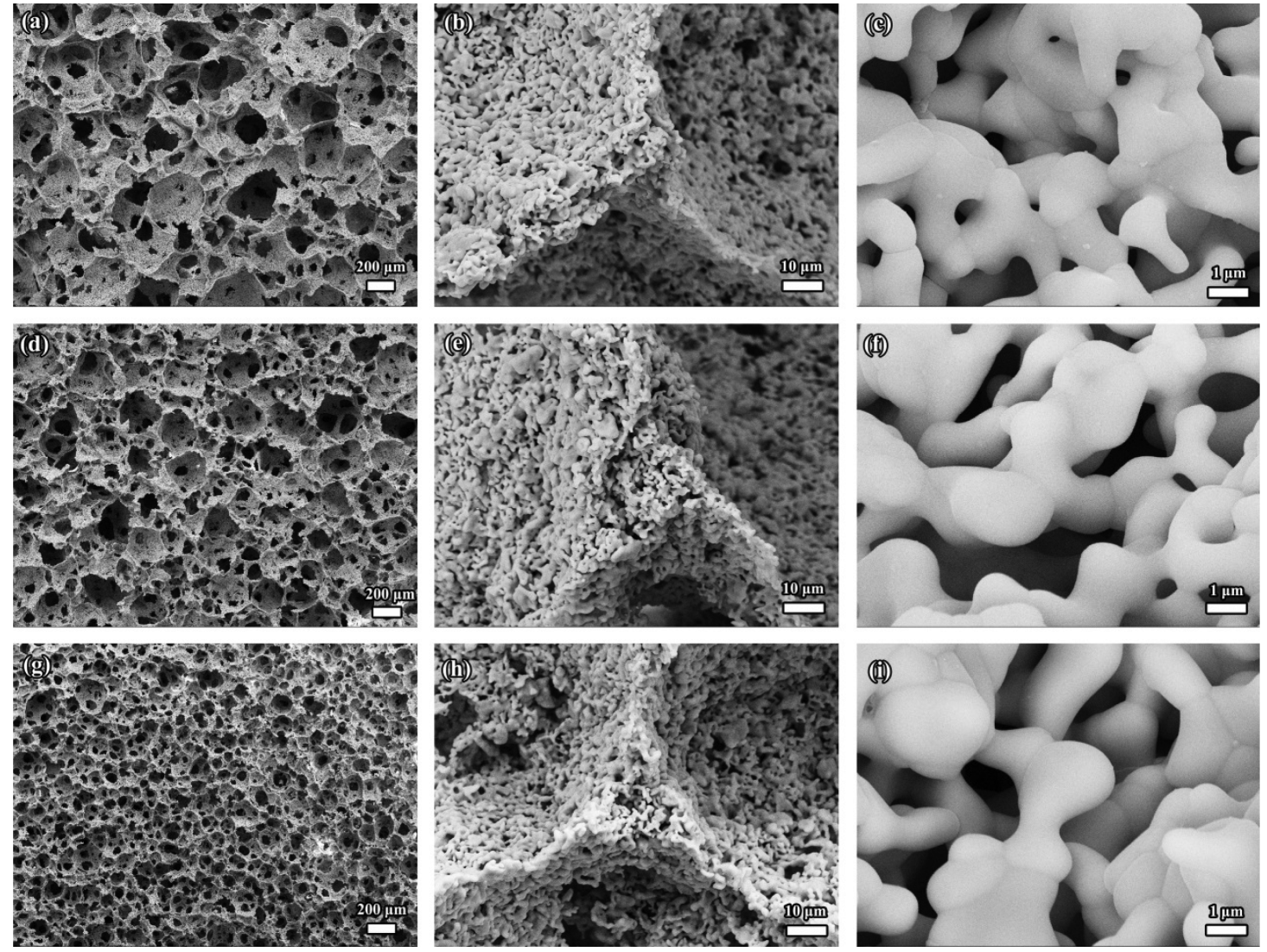

Fig. 17. Microstructures of porous $\mathrm{Y}_{2} \mathrm{SiO}_{5}$ ceramic with different solid contents fabricated by in-situ foam-gelcasting-freeze drying method: (a), (b), and (c) show the large pores, small pores, and grains, respectively, for 10 vol.\% solid content; (d), (e), and (f) are the SEM images corresponding to 15 vol.\% solids; and (g), (h), and (i) are the SEM images corresponding to 20 vol.\% solids. Reproduced with permission from reference. ${ }^{39)}$

by the (direct and in-situ) foam-gelcasting methods reveal large pores and wide pore size distributions. Besides, when $\mathrm{Y}_{2} \mathrm{SiO}_{5}$ powder is used as the raw material, shrinkage is large, especially at higher temperatures $\left(1450-1550^{\circ} \mathrm{C}\right)$. However, the samples prepared by the in-situ process have very low shrinkages, even at the high temperature of $1550^{\circ} \mathrm{C}$, which is beneficial for net-shape forming. As far as the porosity and density are concerned, the in-situ sintering process could result in quite a high porosity and very low density, compared to those of all the direct sintering processes.

As for the thermal conductivity, it is easy to understand that the porous $\mathrm{Y}_{2} \mathrm{SiO}_{5}$ with a very high porosity has an extremely low thermal conductivity, on the foundation of the low intrinsic thermal conductivity of $\mathrm{Y}_{2} \mathrm{SiO}_{5}$ matrix $(1.86 \mathrm{~W} /(\mathrm{m} \cdot \mathrm{K})$ at room temperature). However, the thermal conductivities are also very low for the porous samples with low porosities that were prepared from $\mathrm{Y}_{2} \mathrm{SiO}_{5}$ starting powder. This phenomenon can perhaps be explained by the low sintering temperature and short holding time. The necks and interfaces formed between the $\mathrm{Y}_{2} \mathrm{SiO}_{5}$ grains are not very tight or firm at low sintering temperatures (1300$1400^{\circ} \mathrm{C}$ ) for $1-2 \mathrm{~h}$; they are definitely weaker and looser than those produced at $1550^{\circ} \mathrm{C}$ for $3 \mathrm{~h}$ by the in-situ process.
As is known, heat transport is more significantly affected by the differences in the morphologies and contact areas of the grains, as well as by the densification of the sintering necks. Thus, the thermal conductivities are low for samples prepared by using $\mathrm{Y}_{2} \mathrm{SiO}_{5}$ powder as the raw material. Moreover, the densification of sintering necks and the contact areas of grains not only influence the thermal conductivity of a porous ceramic but also affect the strength of a porous material. From Table 3, it can be seen that the compressive strengths are all relatively low for the samples fabricated from $\mathrm{Y}_{2} \mathrm{SiO}_{5}$ powder. The low strength mainly results from the weak sintering necks. It also indicates loose interface bonding. In comparison, the in-situ sintering process could realize light weight, low thermal conductivity, and high strength simultaneously.

\subsubsection{Porous $\mathrm{Y}_{2} \mathrm{SiO}_{5}$ ceramic composite materials}

In order to obtain a material that exhibits a better performance, a common and feasible method is to prepare composites. By utilizing the advantages of the second phase, new composite materials having better overall properties can be fabricated through powerful combination. When porous $\mathrm{Y}_{2} \mathrm{SiO}_{5}$ ceramics are prepared as composites, they exhibit higher strengths and lower thermal conductivities. These 
Table 3. Comparison of the Properties of Porous Rare Earth Silicate Ceramics Fabricated by Different Methods

\begin{tabular}{|c|c|c|c|c|c|c|c|c|c|}
\hline $\begin{array}{l}\text { Porous } \\
\text { ceramic }\end{array}$ & $\begin{array}{l}\text { Tempera- } \\
\text { ture } \\
\left({ }^{\circ} \mathrm{C}\right)\end{array}$ & $\begin{array}{l}\text { Pore size } \\
\quad(\mu \mathrm{m})\end{array}$ & $\begin{array}{l}\text { Shrink- } \\
\text { age } \\
(\%)\end{array}$ & $\begin{array}{l}\text { Porosity } \\
\quad(\%)\end{array}$ & $\begin{array}{l}\text { Density } \\
\left(\mathrm{g} / \mathrm{cm}^{3}\right)\end{array}$ & $\begin{array}{c}\text { Thermal } \\
\text { conductivity } \\
(\mathrm{W} /(\mathrm{m} \cdot \mathrm{K}))\end{array}$ & $\begin{array}{l}\text { Compressive } \\
\text { strength } \\
\text { (MPa) }\end{array}$ & $\begin{array}{l}\text { Highest } \\
\text { porosity } \\
(\%)\end{array}$ & Method \\
\hline $\mathrm{Y}_{2} \mathrm{SiO}_{5}$ & $\begin{array}{l}1300 \\
(1 \mathrm{~h})\end{array}$ & $\begin{array}{c}40 \\
\left(\mathrm{~d}_{50}\right)\end{array}$ & I & $72-45$ & $1.24-2.44$ & $0.05-0.10$ & $3.1-23.2$ & $\begin{array}{c}72 \\
\left(1300^{\circ} \mathrm{C}\right)\end{array}$ & $\begin{array}{l}\text { TBA-based } \\
\text { freeze casting }\end{array}$ \\
\hline $\mathrm{Y}_{2} \mathrm{SiO}_{5}$ & $\begin{array}{l}1250-1450 \\
\quad(2 \mathrm{~h})\end{array}$ & $\begin{array}{c}50-25 \\
\left(\mathrm{~d}_{50}\right)\end{array}$ & $\begin{array}{l}13.5- \\
20.8\end{array}$ & $71-62$ & $1.29-1.69$ & $0.07-0.22$ & $3.34-16.51$ & $\begin{array}{c}71 \\
\left(1250^{\circ} \mathrm{C}\right)\end{array}$ & $\begin{array}{l}\text { Water-based } \\
\text { freeze casting }{ }^{27)}\end{array}$ \\
\hline $\mathrm{Y}_{2} \mathrm{SiO}_{5}$ & $\begin{array}{l}1300 \\
(1 \mathrm{~h})\end{array}$ & $\begin{array}{c}40-10 \\
\left(d_{50}\right)\end{array}$ & $\begin{array}{l}14.6- \\
22.7\end{array}$ & $72-52$ & $1.24-2.13$ & I & $1.87-8.42$ & $\begin{array}{c}72 \\
\left(1300^{\circ} \mathrm{C}\right)\end{array}$ & $\begin{array}{l}\text { Water-based } \\
\text { freeze casting }\end{array}$ \\
\hline $\mathrm{Y}_{2} \mathrm{SiO}_{5}$ & $\begin{array}{l}1200-1500 \\
(2 \mathrm{~h})\end{array}$ & $\begin{array}{c}2.90-2.17 \\
\left(\mathrm{~d}_{50}\right)\end{array}$ & $\begin{array}{l}9.69- \\
18.85\end{array}$ & $\begin{array}{c}67.09- \\
58.31\end{array}$ & $0.99-1.32$ & $0.13-0.20$ & $3.34-16.51$ & $\begin{array}{c}73.93 \\
\left(1200^{\circ} \mathrm{C}\right)\end{array}$ & $\begin{array}{l}\text { TBA-based } \\
\text { gel-casting }\end{array}$ \\
\hline $\mathrm{Y}_{2} \mathrm{SiO}_{5}$ & $\begin{array}{l}1500 \\
(2 \mathrm{~h})\end{array}$ & $\begin{array}{l}1.02-2.01 \\
\left(\mathrm{~d}_{50}\right)\end{array}$ & l & $\begin{array}{l}61.7- \\
29.6\end{array}$ & $1.70-3.12$ & $0.18-0.81$ & $28.25-1.43$ & $\begin{array}{c}61.7 \\
\left(1500^{\circ} \mathrm{C}\right)\end{array}$ & Pore-forming agent ${ }^{38)}$ \\
\hline $\mathrm{Y}_{2} \mathrm{SiO}_{5}$ & $\begin{array}{l}1350-1550 \\
\quad(2 \mathrm{~h})\end{array}$ & $\begin{array}{l}30-260 \\
\text { (L) }\end{array}$ & $3.8-19.8$ & $\begin{array}{l}79.8- \\
64.1\end{array}$ & $0.90-1.59$ & $\begin{array}{c}0.58 \\
(\mathrm{P}=62.5 \%)\end{array}$ & $3.26-16.70$ & $\begin{array}{c}79.8 \\
\left(1350^{\circ} \mathrm{C}\right)\end{array}$ & Foam-gelcasting ${ }^{28)}$ \\
\hline $\mathrm{Y}_{2} \mathrm{SiO}_{5}$ & $\begin{array}{l}1550 \\
(3 \mathrm{~h})\end{array}$ & $\begin{array}{l}30-400 \\
\text { (L) }\end{array}$ & $6.3-4.5$ & $\begin{array}{l}88.4- \\
60.7\end{array}$ & $0.52-1.74$ & $\begin{array}{c}0.126-0.513 \\
(\mathrm{P}=87.1 \%- \\
60.2 \%)\end{array}$ & $0.9-38.2$ & $\begin{array}{c}88.4 \\
\left(1550^{\circ} \mathrm{C}\right)\end{array}$ & $\begin{array}{l}\text { In-situ } \\
\text { foam-gelcasting }\end{array}$ \\
\hline $\mathrm{Y}_{2} \mathrm{SiO}_{5}$ & $\begin{array}{l}1550 \\
(3 \mathrm{~h})\end{array}$ & $\begin{array}{l}45-500 \\
(\mathrm{~L})\end{array}$ & $5.0-7.7$ & $\begin{array}{c}95.8- \\
92.2\end{array}$ & $0.19-0.35$ & $0.054-0.089$ & I & $\begin{array}{c}95.8 \\
\left(1550^{\circ} \mathrm{C}\right)\end{array}$ & $\begin{array}{l}\text { In-situ foam-gelcast- } \\
\text { ing-freeze drying }{ }^{39)}\end{array}$ \\
\hline Aerogel $/ \mathrm{Y}_{2} \mathrm{SiO}_{5}$ & $\begin{array}{l}1400 \\
(1 \mathrm{~h})\end{array}$ & $\begin{array}{l}18.2-12.1 \\
0.05-0.08\end{array}$ & I & $\begin{array}{c}86.4- \\
71.1\end{array}$ & $0.61-1.29$ & $0.069-0.260$ & $0.9-9.3$ & $\begin{array}{c}86.4 \\
\left(1400^{\circ} \mathrm{C}\right)\end{array}$ & $\begin{array}{l}\text { Freeze casting and } \\
\text { sol-gel impregnation }^{69)}\end{array}$ \\
\hline $\begin{array}{l}\mathrm{ZrO}_{2} \text { fiber/ } \\
\mathrm{Y}_{2} \mathrm{SiO}_{5}\end{array}$ & $\begin{array}{l}1250-1450 \\
(45 \mathrm{~min})\end{array}$ & $0.1-1.5$ & l & $\begin{array}{l}41.2- \\
27.2\end{array}$ & $2.72-3.14$ & $0.33-0.56$ & $14.8-65.7$ & $\begin{array}{c}41.2 \\
\left(1250^{\circ} \mathrm{C}\right)\end{array}$ & $\begin{array}{l}\text { Pressureless sintering } \\
\left(\mathrm{Y}_{2} \mathrm{SiO}_{5} \text { nanopowder }\right)^{70)}\end{array}$ \\
\hline $\mathrm{Yb}_{2} \mathrm{SiO}_{5}$ & $\begin{array}{l}1350-1550 \\
\quad(1 \mathrm{~h})\end{array}$ & $\begin{array}{c}10-40 \\
\left(\mathrm{~d}_{50}\right)\end{array}$ & $2.2-14.8$ & $\begin{array}{l}85.7- \\
71.2\end{array}$ & $0.98-1.99$ & $0.113-0.301$ & $2.82-7.01$ & $\begin{array}{c}85.7 \\
\left(1550^{\circ} \mathrm{C}\right)\end{array}$ & $\begin{array}{l}\text { Water-based } \\
\text { freeze casting }{ }^{41)}\end{array}$ \\
\hline $\mathrm{Yb}_{2} \mathrm{SiO}_{5}$ & $\begin{array}{l}1150-1550 \\
\quad(1 \mathrm{~h})\end{array}$ & $\begin{array}{c}10-50 \\
\left(d_{50}\right)\end{array}$ & $\begin{array}{c}1.45- \\
7.60\end{array}$ & $\begin{array}{l}85.65- \\
82.15\end{array}$ & $0.99-1.23$ & $0.117-0.132$ & $1.89-3.36$ & $\begin{array}{c}85.65 \\
\left(1150^{\circ} \mathrm{C}\right)\end{array}$ & $\begin{array}{l}\text { Water-based } \\
\text { freeze casting }\end{array}$ \\
\hline$\gamma-\mathrm{Y}_{2} \mathrm{Si}_{2} \mathrm{O}_{7}$ & $\begin{array}{l}1550 \\
(2 \mathrm{~h})\end{array}$ & $200-700$ & I & 84.5 & 0.62 & I & 1.25 & $\begin{array}{c}84.5 \\
\left(1550^{\circ} \mathrm{C}\right)\end{array}$ & $\begin{array}{l}\text { Polymeric sponge } \\
\text { impregnation }^{29)}\end{array}$ \\
\hline$\gamma-\mathrm{Y}_{2} \mathrm{Si}_{2} \mathrm{O}_{7}$ & $\begin{array}{l}1550 \\
(2 \mathrm{~h})\end{array}$ & $\begin{array}{l}\text { 60-250 } \\
\text { (L) }\end{array}$ & 6.0 & 84.9 & 0.61 & 0.230 & 6.22 & $\begin{array}{c}84.9 \\
\left(1550^{\circ} \mathrm{C}\right)\end{array}$ & $\begin{array}{l}\text { In-situ } \\
\text { foam-gelcasting }{ }^{40)}\end{array}$ \\
\hline$\gamma-\mathrm{Y}_{2} \mathrm{Si}_{2} \mathrm{O}_{7}$ & $\begin{array}{l}1550 \\
(2 \mathrm{~h})\end{array}$ & $\begin{array}{l}40-250 \\
(\mathrm{~L})\end{array}$ & $6.1-9.9$ & $\begin{array}{l}89.3- \\
64.3\end{array}$ & $0.43-1.44$ & $\begin{array}{c}0.14-0.918 \\
(90 \%-57.2 \%)\end{array}$ & $3.4-46.5$ & $\begin{array}{c}89.3 \\
\left(1550^{\circ} \mathrm{C}\right)\end{array}$ & $\begin{array}{l}\text { In-situ } \\
\text { foam-gelcasting }{ }^{102)}\end{array}$ \\
\hline$\gamma-\left(\mathrm{Y}_{1-\mathrm{x}} \mathrm{Ho}_{\mathrm{x}}\right)_{2} \mathrm{Si}_{2} \mathrm{O}_{7}$ & $\begin{array}{l}1550 \\
(2 \mathrm{~h})\end{array}$ & $\begin{array}{l}\text { 30-310 } \\
\text { (L) }\end{array}$ & $4.7-10.2$ & $\begin{array}{l}81.2- \\
78.3\end{array}$ & $0.76-1.24$ & $0.180-0.309$ & $11.5-12.0$ & $\begin{array}{c}81.2 \\
\left(1550^{\circ} \mathrm{C}\right)\end{array}$ & $\begin{array}{l}\text { In-situ foam-gelcast- } \\
\text { ing }+ \text { solid solution }^{43)}\end{array}$ \\
\hline $\begin{array}{l}\text { YSZ fiber/ } \\
\gamma-\mathrm{Y}_{2} \mathrm{Si}_{2} \mathrm{O}_{7}\end{array}$ & $\begin{array}{l}1550 \\
(2 \mathrm{~h})\end{array}$ & $\begin{array}{l}40-360 \\
(\mathrm{~L})\end{array}$ & $9.2-6.6$ & $\begin{array}{l}93.5- \\
92.7\end{array}$ & $0.26-0.32$ & $0.107-0.090$ & $0.99-1.36$ & $\begin{array}{c}93.5 \\
\left(1550^{\circ} \mathrm{C}\right)\end{array}$ & $\begin{array}{l}\text { In-situ foam-gelcast- } \\
\text { ing-freeze drying }\end{array}$ \\
\hline
\end{tabular}

$\mathrm{d}_{50}$ : mean pore size; the listed data are the mean pore sizes of different samples obtained under different conditions, therefore, note that 50-25 (second row, third column) does not represent the pore size distribution of one sample. Here, $50 \mu \mathrm{m}$ is the mean pore size of the sample sintered at $1250^{\circ} \mathrm{C}$ (the pore distribution is very narrow for one sample); L: large pores; the listed data are the summed pore distributions of several samples, therefore, the entry 45-500 represents the total of 45-260, 60-400, and 70-500 (the pore distribution is very wide for one sample); P: porosity.

materials would then become outstanding thermal insulators. For instance, silica aerogel/porous $\mathrm{Y}_{2} \mathrm{SiO}_{5}$ ceramic and $\mathrm{ZrO}_{2}$ fiber/porous $\mathrm{Y}_{2} \mathrm{SiO}_{5}$ ceramic composites have emerged ${ }^{69,70)}$

\subsubsection{Silica aerogel/porous $\mathrm{Y}_{2} \mathrm{SiO}_{5}$ ceramic composite}

At present, silica aerogel is the type of thermal insulation material with the highest porosity (99\%), lowest density $\left(0.003 \mathrm{~g} / \mathrm{cm}^{3}\right)$, and lowest thermal conductivity $(0.015 \mathrm{~W} /$ $(\mathrm{m} \cdot \mathrm{K}))^{90-92)}$ Unfortunately, the strength of this excellent thermal insulator is very low owing to the extremely high porosity and delicate nanoskeleton. However, one of the virtues of porous ceramics is the high specific strength. There- fore, the silica aerogel/porous ceramic composite materials could concurrently have low thermal conductivity and high strength. In this condition, silica aerogel-impregnated porous $\mathrm{Y}_{2} \mathrm{SiO}_{5}$ ceramic composite was synthesized by freeze casting and sol-gel impregnation. ${ }^{69}$

Figure 18 shows the microstructures of porous $\mathrm{Y}_{2} \mathrm{SiO}_{5}$ ceramic before and after impregnation with silica aerogel. The original porous $\mathrm{Y}_{2} \mathrm{SiO}_{5}$ contains pores with $3 \mathrm{D}$ reticular shapes, as observed in Fig. 18(a). The microstructure of the silica aerogel-impregnated porous $\mathrm{Y}_{2} \mathrm{SiO}_{5}$ ceramic is shown in Fig. 18(b). It is observed that silica aerogel distinctly occupies almost all the pore channels of the porous $\mathrm{Y}_{2} \mathrm{SiO}_{5}$ 

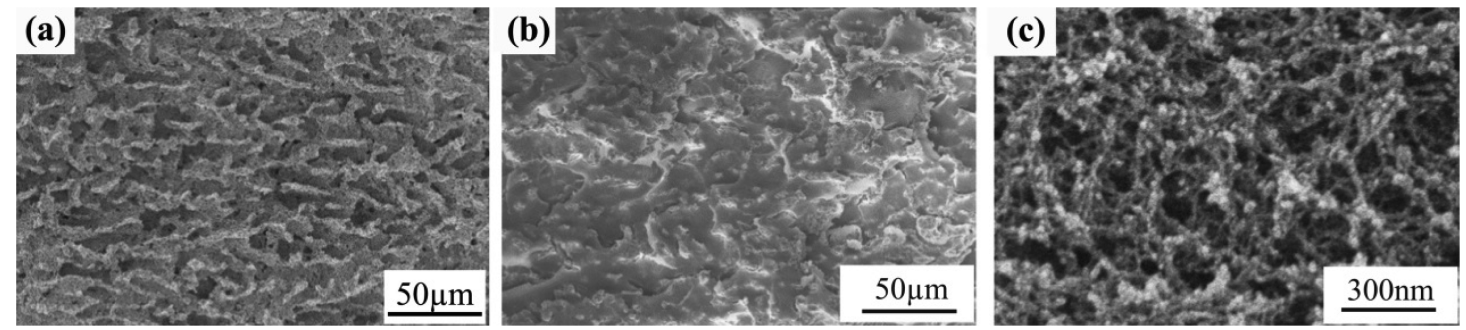

Fig. 18. SEM images of porous $\mathrm{Y}_{2} \mathrm{SiO}_{5}$ ceramic (a) before and (b) after impregnation with silica aerogel and (c) silica aerogel in the pore channel. Reproduced with permission from reference. ${ }^{69}$

Table 4. Porosity, Thermal Conductivity, and Compressive Strength of Porous $\mathrm{Y}_{2} \mathrm{SiO}_{5}$ Ceramic before and after Impregnation with Silica Aerogel. Reproduced with permission from reference ${ }^{69}$

\begin{tabular}{|c|c|c|c|c|c|c|}
\hline $\begin{array}{l}\text { Solid content } \\
\quad \text { (vol.\%) }\end{array}$ & $\begin{array}{l}\text { Porosity } \\
\text { (\%) }\end{array}$ & $\begin{array}{l}\text { Thermal conductivity } \\
(\mathrm{W} / \mathrm{m} \cdot \mathrm{K})\end{array}$ & $\begin{array}{c}\text { Compressive } \\
\operatorname{strength}^{\mathrm{b}}(\mathrm{MPa})\end{array}$ & $\begin{array}{l}\text { Porosity }{ }^{a} \\
(\%)\end{array}$ & $\begin{array}{l}\text { Thermal conductivity } \\
(\mathrm{W} / \mathrm{m} \cdot \mathrm{K})\end{array}$ & $\begin{array}{c}\text { Compressive strength }{ }^{\mathrm{a}} \\
(\mathrm{MPa})\end{array}$ \\
\hline 10 & 88.4 & $0.079 \pm 0.0002$ & $0.5 \pm 0.07$ & 86.4 & $0.069 \pm 0.004$ & $0.9 \pm 0.3$ \\
\hline 15 & 83.9 & $0.148 \pm 0.006$ & $1.6 \pm 0.13$ & 81.7 & $0.115 \pm 0.002$ & $2.4 \pm 0.2$ \\
\hline 20 & 79.8 & $0.178 \pm 0.005$ & $2.1 \pm 0.20$ & 77.7 & $0.141 \pm 0.004$ & $3.2 \pm 0.5$ \\
\hline 25 & 73.3 & $0.286 \pm 0.010$ & $5.1 \pm 0.15$ & 71.1 & $0.260 \pm 0.006$ & $9.3 \pm 0.3$ \\
\hline
\end{tabular}

The superscripts a and $b$ denote values after and before impregnation with aerogels, respectively.

matrix. Furthermore, silica aerogel presents a kind of continuous 3D network structure with homogeneous nanopores of size 50-80 nm, as shown in Fig. 18(c). This type of nanopore structure can remarkably reduce solid conductiv- ity, gas conductivity, and thermal radiation, and restrain air convection. Therefore, extremely low thermal conductivity can be obtained.

As expected, the silica aerogel-impregnated porous $\mathrm{Y}_{2} \mathrm{SiO}_{5}$
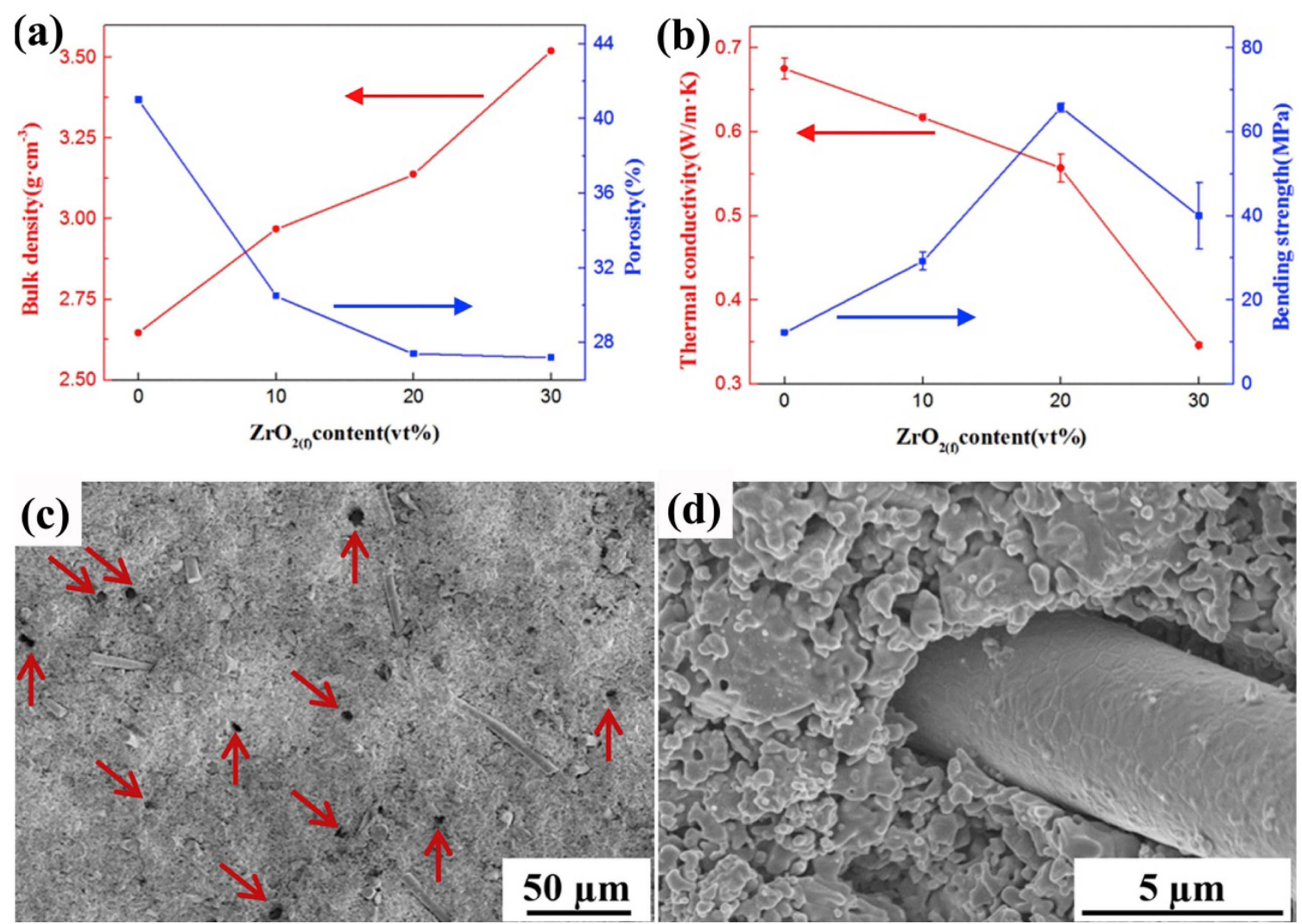

Fig. 19. (a, b) Properties and (c, d: 20 vol.\%) fracture morphologies of porous $\mathrm{Y}_{2} \mathrm{SiO}_{5}$ ceramic with different $\mathrm{ZrO}_{2}$ fiber contents. Reproduced with permission from reference. ${ }^{70)}$ 

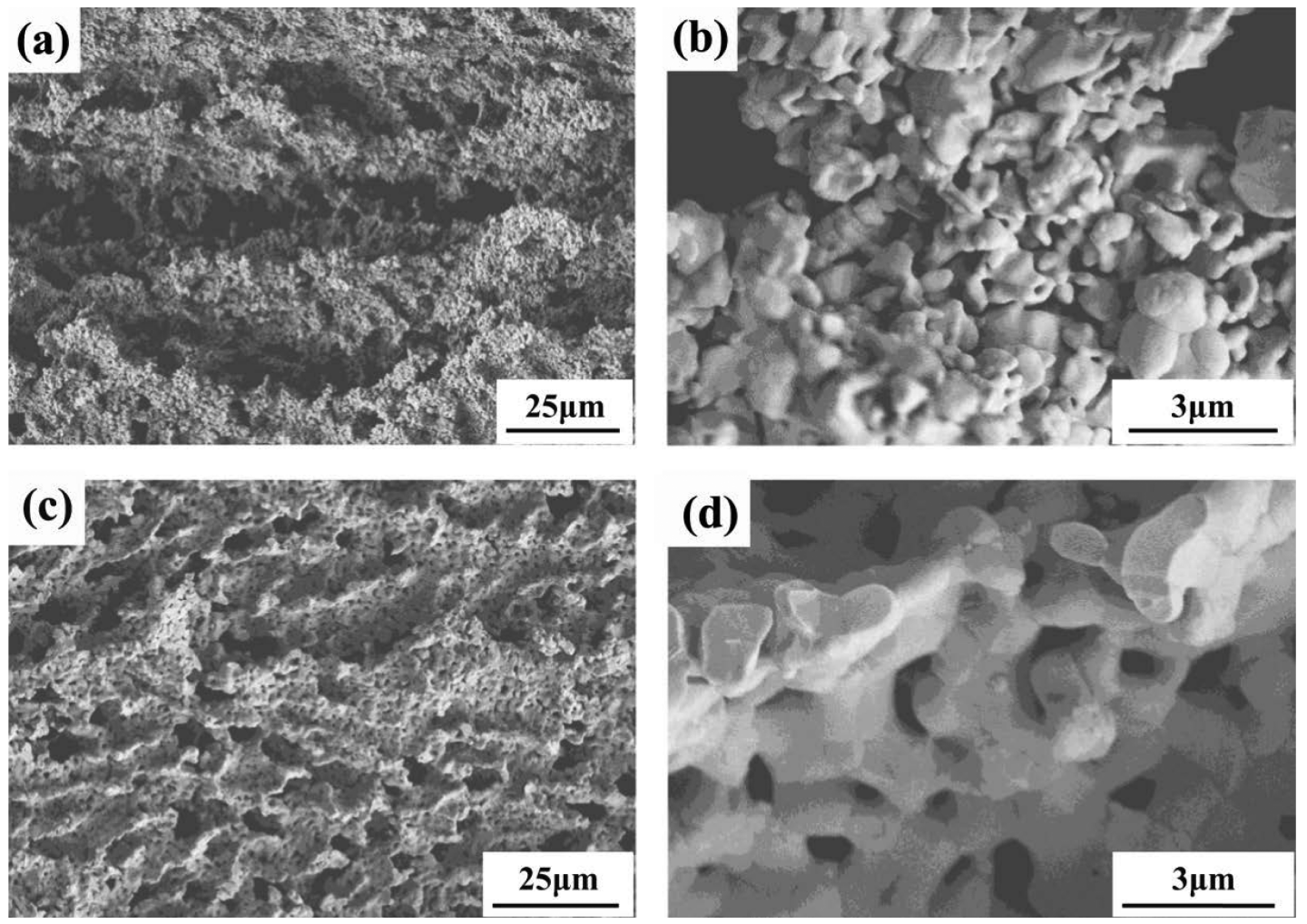

Fig. 20. SEM images of porous $\mathrm{Yb}_{2} \mathrm{SiO}_{5}$ ceramic with different solid contents: (a) and (b) show lamellar channel pores and small pores for 15 vol.\%, whereas (c) and (d) reveal the lamellar channel pores and small pores for 25 vol.\%. Reproduced with permission from reference. ${ }^{41)}$

ceramic displays obviously better properties than pure porous $\mathrm{Y}_{2} \mathrm{SiO}_{5}$, as indicated in Table 4 . It can be seen that the room temperature thermal conductivity decreases and the compressive strength increases remarkably after silica aerogel is impregnated into porous $\mathrm{Y}_{2} \mathrm{SiO}_{5}$ ceramic. It is understandable that the introduction of silica aerogel reduces the thermal conductivity of the samples greatly, due to the prominent heat-shielding performance of the aerogel through the inhibition of heat transmission. The increase in the strength is ascribed to the decrease in the porosity and the stiffened network due to the impregnation with silica aerogel. ${ }^{69)}$

\subsubsection{2. $\mathrm{ZrO}_{2}$ fiber/porous $\mathrm{Y}_{2} \mathrm{SiO}_{5}$ ceramic composite}

In order to improve the mechanical properties of porous ceramics, fiber reinforcement is a frequently used effective method. Zhang et al. prepared $\mathrm{ZrO}_{2}$-fiber-reinforced porous $\mathrm{Y}_{2} \mathrm{SiO}_{5}$ ceramic by a simple pressureless sintering process, using $\mathrm{Y}_{2} \mathrm{SiO}_{5}$ nanoparticles prepared through sol-gel method as the raw material. ${ }^{70)}$ The results indicate that the strength and thermal conductivity of the $\mathrm{ZrO}_{2}$-fiber-reinforced porous $\mathrm{Y}_{2} \mathrm{SiO}_{5}$ nanocomposites are improved greatly when the fibers are added, as shown in Fig. 19. The increase in strength is due to fiber pullout (Fig. 19(c)) and the decrease in density. On the other hand, the decrease in the thermal conductivity is possibly because of the enhancement in the interfacial thermal resistance with the increase in fiber con- tent. Moreover, the composite material with 20 vol. $\% \mathrm{ZrO}_{2}$ fibers exhibits optimum strengthening effects.

\subsubsection{Porous $\mathrm{Yb}_{2} \mathrm{SiO}_{5}$ ceramic}

As mentioned earlier, porous $\mathrm{Yb}_{2} \mathrm{SiO}_{5}$ ceramic is a new member of porous $\mathrm{RE}_{2} \mathrm{SiO}_{5}$ materials. Water-based freeze casting technique was employed to fabricate porous $\mathrm{Yb}_{2} \mathrm{SiO}_{5}$ by using synthesized $\mathrm{Yb}_{2} \mathrm{SiO}_{5}$ powder as the starting mate-

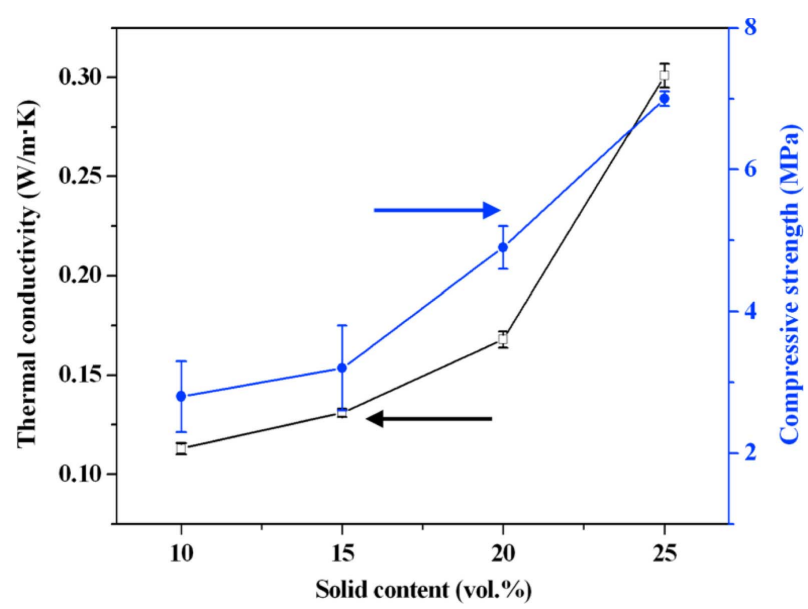

Fig. 21. Compressive strengths and thermal conductivities of porous $\mathrm{Yb}_{2} \mathrm{SiO}_{5}$ ceramic with different solid contents. ${ }^{41)}$ 
Table 5. Influence of Sintering Temperature on the Linear Shrinkage, Density, and Porosity of Samples, and the Linear Shrinkage Obtained after Calcination of Porous $\mathrm{Yb}_{2} \mathrm{SiO}_{5}$ Ceramic with 15 vol.\% Solid Content at $1500^{\circ} \mathrm{C}$

\begin{tabular}{ccccc}
\hline $\begin{array}{c}\text { Sintering } \\
\text { temperature } \\
\left({ }^{\circ} \mathrm{C}\right)\end{array}$ & $\begin{array}{c}\text { Linear } \\
\text { shrinkage } \\
(\%)\end{array}$ & $\begin{array}{c}\text { Bulk } \\
\text { density } \\
\left(\mathrm{g} / \mathrm{cm}^{3}\right)\end{array}$ & $\begin{array}{c}\text { Porosity } \\
(\%)\end{array}$ & $\begin{array}{c}\text { Resintering } \\
\text { shrinkage } \\
\text { at } 1500^{\circ} \mathrm{C}(\%)\end{array}$ \\
\hline 1150 & 1.45 & 0.99 & 85.65 & 29 \\
1250 & 2.10 & 1.02 & 85.20 & 20.5 \\
1350 & 3.65 & 1.06 & 84.65 & 15 \\
1450 & 4.85 & 1.11 & 83.95 & 0.2 \\
1550 & 7.60 & 1.23 & 82.15 & 0 \\
\hline
\end{tabular}

rial. ${ }^{41)}$ The as-prepared porous sample reveals multiple pore structures, including lamellar channel pores and small pores in the skeleton (Fig. 20). The corresponding pore size distributions are $10-40 \mu \mathrm{m}$ and $0.2-1.0 \mu \mathrm{m}$, respectively. From Fig. 21, it is observed that the porous $\mathrm{Yb}_{2} \mathrm{SiO}_{5}$ sample exhibits good properties such as low thermal conductivity $(0.113-0.301 \mathrm{~W} /(\mathrm{m} \cdot \mathrm{K}))$ and high strength $(2.82-7.01 \mathrm{MPa})$. Besides, the linear shrinkage $(2.2 \%-14.8 \%)$ is low and the porosity $(71.2 \%-85.7 \%)$ is high for porous $\mathrm{Yb}_{2} \mathrm{SiO}_{5}$, as presented in Table 3. In particular, when the content of solids is higher than 15 vol.\%, the sintering shrinkage is lower than $7.2 \%$, even at the high temperature of $1550^{\circ} \mathrm{C}$. It indicates that $\mathrm{Yb}_{2} \mathrm{SiO}_{5}$ powder has better sintering resistance than $\mathrm{Y}_{2} \mathrm{SiO}_{5}$ powder. Therefore, the porosity of porous $\mathrm{Yb}_{2}$ $\mathrm{SiO}_{5}$ is much higher than that of porous $\mathrm{Y}_{2} \mathrm{SiO}_{5}$, when the raw materials are synthesized $\mathrm{RE}_{2} \mathrm{SiO}_{5}$ powders. These results indicate that porous $\mathrm{Yb}_{2} \mathrm{SiO}_{5}$ ceramic is a good candidate for high-temperature thermal insulation materials.

Additionally, Han et al. investigated the effects of sintering temperature and recalcination on the properties of porous $\mathrm{Yb}_{2} \mathrm{SiO}_{5}$ ceramic with 15 vol.\% solids. ${ }^{42)}$ The study found that the shrinkage of the porous sample is quite low, ranging from $1.45 \%$ to $7.60 \%$ as the sintering temperature increases from $1150^{\circ} \mathrm{C}$ to $1550^{\circ} \mathrm{C}$. Owing to the low shrinkage, the porosity obtained is high $(82.15 \%-85.65 \%)$. It should be mentioned here that the linear shrinkage is quite large $(15 \%-29 \%)$ for the porous $\mathrm{Yb}_{2} \mathrm{SiO}_{5}$ ceramic prepared at $1150-1350^{\circ} \mathrm{C}$ after the sample was calcined at $1500^{\circ} \mathrm{C}$, as shown in Table 5. Compared to the shrinkage of $4.85 \%$ observed between the green body and the porous ceramic sintered at $1450^{\circ} \mathrm{C}$ and the shrinkage of $0.2 \%$ obtained after calcination at $1500^{\circ} \mathrm{C}$, the values of resintering shrinkages $(20.5 \%-29 \%)$ are too large for the samples prepared at $1150^{\circ} \mathrm{C}$ and $1250^{\circ} \mathrm{C}$. Therefore, it is concluded that the porous material should be sintered at a high temperature, if it is to be utilized as a high-temperature thermal insulator. From the point of view of safety during service, a porous ceramic thermal insulator should be sintered at relatively high temperatures. Compared with other porous ceramics, if the density of the sample can be made much lower for the condition of a similar porosity, it would be better and of importance for porous $\mathrm{Yb}_{2} \mathrm{SiO}_{5}$.

\subsection{Porous $\gamma-\mathrm{RE}_{2} \mathrm{Si}_{2} \mathrm{O}_{7}$ ceramic}

In general, it is quite difficult to prepare stoichiometric pure-phase $\mathrm{Y}_{2} \mathrm{Si}_{2} \mathrm{O}_{7}$ by the solid-state reaction of $\mathrm{Y}_{2} \mathrm{O}_{3}$ and $\mathrm{SiO}_{2}$ powders without using any sintering additives. ${ }^{93,94)}$ The reasons are there are many polymorphs of yttrium disilicate (y, $\alpha, \beta, \gamma, \delta$, and possibly $\mathrm{z}$ ) and the region of existence of $\gamma$ $\mathrm{Y}_{2} \mathrm{Si}_{2} \mathrm{O}_{7}$ in the $\mathrm{Y}_{2} \mathrm{O}_{3}-\mathrm{SiO}_{2}$ phase diagram is quite narrow. ${ }^{3695)}$ Besides, most researches make use of the same starting powder as the target product to fabricate porous ceramics, and there is virtually no chemical reaction occurring during the preparation process. For example, $\mathrm{SiO}_{2}$, $\mathrm{Al}_{2} \mathrm{O}_{3}, \mathrm{SiC}, \mathrm{Si}_{3} \mathrm{~N}_{4}$, mullite, hydroxyapatite, and $\mathrm{Y}_{2} \mathrm{SiO}_{5}$ powders are used as the raw materials to prepare porous $\mathrm{SiO}_{2}$, $\mathrm{Al}_{2} \mathrm{O}_{3}, \mathrm{SiC}, \mathrm{Si}_{3} \mathrm{~N}_{4}$, mullite, hydroxyapatite, and $\mathrm{Y}_{2} \mathrm{SiO}_{5}$ ceramics, respectively. ${ }^{26,96-101)}$ Owing to the difficulty of preparing pure $\gamma-\mathrm{Y}_{2} \mathrm{Si}_{2} \mathrm{O}_{7}$ powder, there have only been a few investigations on porous $\gamma-\mathrm{Y}_{2} \mathrm{Si}_{2} \mathrm{O}_{7}$ ceramic, which were carried out by the High-Performance Ceramics Division of the Institute of Metal Research, Chinese Academy of Sciences. ${ }^{29,30,40,43,102)}$ Furthermore, the in-situ reaction sintering technique was employed to fabricate porous $\gamma-\mathrm{Y}_{2} \mathrm{Si}_{2} \mathrm{O}_{7}$ ceramic by using $\mathrm{Y}_{2} \mathrm{SiO}_{5}$ powder and $\mathrm{SiO}_{2}$ sol or $\mathrm{Y}_{2} \mathrm{O}_{3}$ and $\mathrm{SiO}_{2}$ powders as the starting materials; single-phase $\gamma$ $\mathrm{Y}_{2} \mathrm{Si}_{2} \mathrm{O}_{7}$ was successfully obtained.

At present, the investigations on porous $\gamma-\mathrm{Y}_{2} \mathrm{Si}_{2} \mathrm{O}_{7}$ ceramic include the preparation of the pure material by different methods and performance optimization through solid solution strengthening and fiber reinforcement. ${ }^{29,30,40,102)}$ To be specific, the preparation methods include polymeric sponge impregnation method, in-situ foam-gelcasting method, and in-situ foam-gelcasting-freeze drying method. Performance optimization refers to the utilization of a solid solution to enhance the high-temperature strength of porous $\gamma-\mathrm{Y}_{2} \mathrm{Si}_{2} \mathrm{O}_{7}$ by adding holmium (oxide) with good high-temperature mechanical properties, while YSZ fiber is added to improve the strength of a porous $\gamma-\mathrm{Y}_{2} \mathrm{Si}_{2} \mathrm{O}_{7}$ sample with superhigh porosity.

\subsubsection{Porous $\gamma-\mathrm{Y}_{2} \mathrm{Si}_{2} \mathrm{O}_{7}$ ceramic}

\subsubsection{Polymeric sponge impregnation}

The first work on porous $\gamma-\mathrm{Y}_{2} \mathrm{Si}_{2} \mathrm{O}_{7}$ ceramic took advantage of the polymeric sponge impregnation method to prepare a reticulated porous sample through reaction bonding process by using $\mathrm{Y}_{2} \mathrm{SiO}_{5}$ powder and silica sol as the raw materials. ${ }^{29)}$ From the X-ray diffraction patterns of the samples, it is observed that pure-phase $\gamma-\mathrm{Y}_{2} \mathrm{Si}_{2} \mathrm{O}_{7}$ could be obtained when $\mathrm{Y}_{2} \mathrm{SiO}_{5}$ powder and silica sol are used as the raw materials at a proper temperature $\left(1550^{\circ} \mathrm{C}\right)$. It is usually referred to as the reaction bonding process for the polymeric sponge impregnation technique, ${ }^{103)}$ and contributes to the excellent mechanical properties of the prepared porous ceramic, which is similar to that obtained from in-situ reaction. The strength of the porous sample could be further improved by the recoating process. ${ }^{104)}$ 

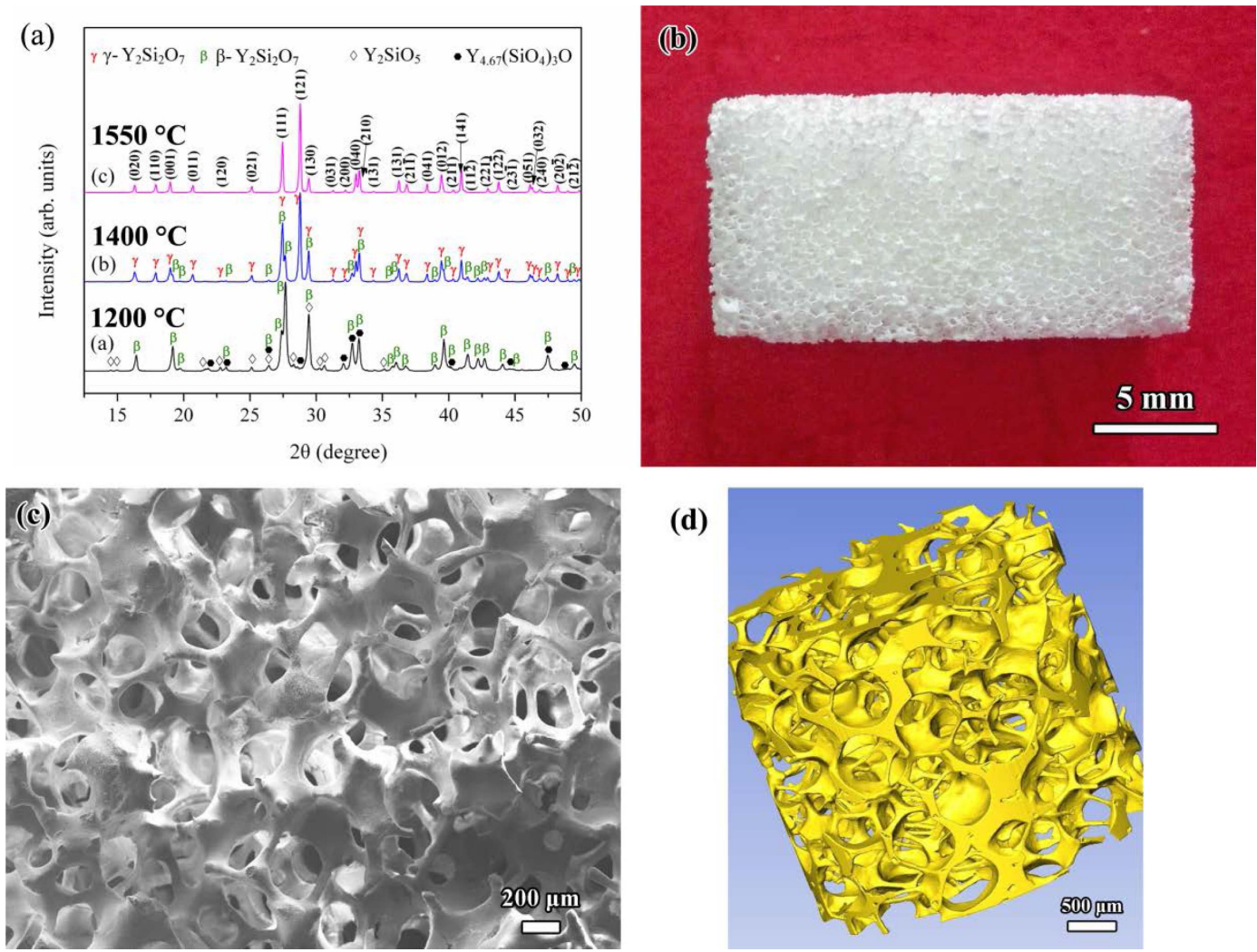

(d)

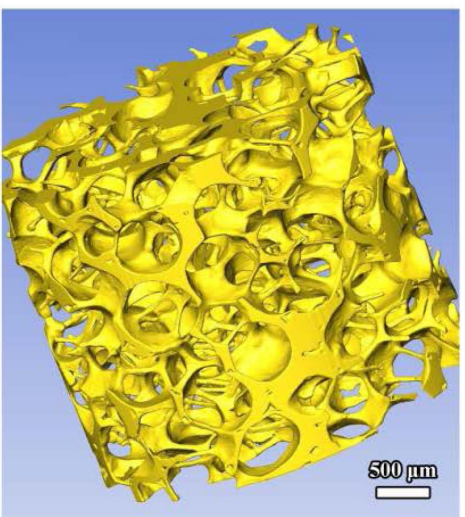

Fig. 22. (a) XRD patterns of porous ceramics sintered at different temperatures, (b) an optical photograph, (c) SEM image, and (d) X-ray tomography image of a typical porous $\gamma-\mathrm{Y}_{2} \mathrm{Si}_{2} \mathrm{O}_{7}$ ceramic prepared by polymeric sponge impregnation method. Reproduced with permission from reference. ${ }^{29}$

As shown in Fig. 22(b-d), the physical sample is a white, open-cell, and reticulated porous ceramic. It has the structure of well interconnected pores of sizes $200-700 \mu \mathrm{m}$. The pore size distribution of the sample is determined by the pore size distribution of the chosen sponge template. Additionally, cracks and triangular holes in the struts of the porous ceramic are eliminated by the recoating technique and there are very few filled cells in the sample. The microstructure of the sample, acquired through XRT analysis, is similar to that observed by SEM, and the XRT image shows that the porous $\gamma-\mathrm{Y}_{2} \mathrm{Si}_{2} \mathrm{O}_{7}$ ceramic contains interconnected open pores, with a uniform distribution of struts. Moreover, the compressive strength, porosity, and density are 1.28 $\mathrm{MPa}, 84.5 \%$, and $0.62 \mathrm{~g} / \mathrm{cm}^{3}$, respectively, which indicate the good properties of the porous $\gamma-\mathrm{Y}_{2} \mathrm{Si}_{2} \mathrm{O}_{7}$ fabricated by the polymeric sponge impregnation method.

Polymeric sponge impregnation technique, as the most traditional preparation method, is well suited for the fabrication of reticulated porous ceramics for application in molten metal filtration, filtration of hot corrosive gases, and catalyst carriers because of their high permeability, good chemical stability, and controlled pore size. ${ }^{6,105,106)}$ In other words, reticulated porous ceramics with excellent permeability and large pores are unfit for use as thermal insulators owing to their high air circulation and high heat radiation. Therefore, in-situ foam-gelcasting method is employed to

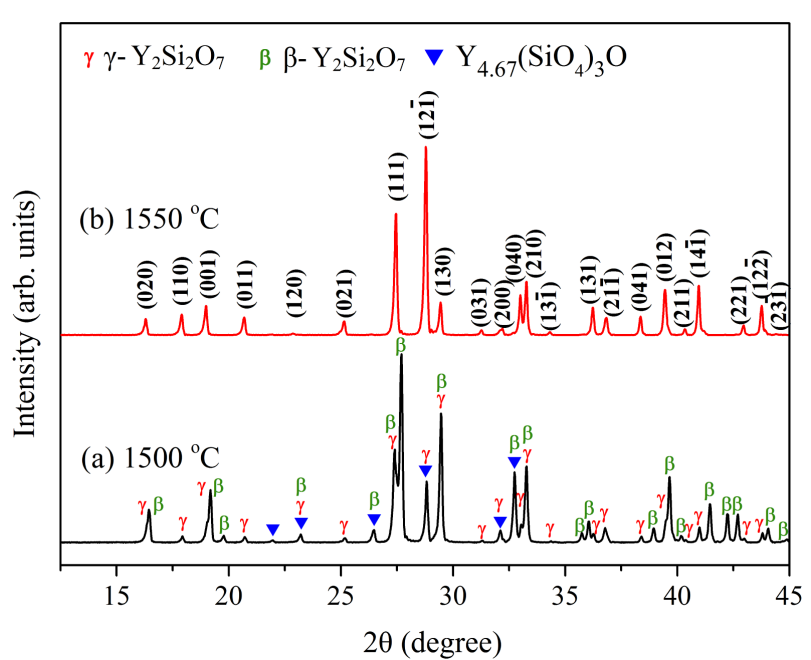

Fig. 23. XRD patterns of porous $\gamma-\mathrm{Y}_{2} \mathrm{Si}_{2} \mathrm{O}_{7}$ sintered at $1500^{\circ} \mathrm{C}$ and $1550^{\circ} \mathrm{C}$ for $2 \mathrm{~h}$. Reproduced with permission from reference. ${ }^{40)}$

fabricate porous $\gamma-\mathrm{Y}_{2} \mathrm{Si}_{2} \mathrm{O}_{7}$ ceramic with low permeability and low thermal conductivity. ${ }^{40,102)}$

\subsubsection{In-situ foam-gelcasting}

In subsequent work, a highly porous $\gamma-\mathrm{Y}_{2} \mathrm{Si}_{2} \mathrm{O}_{7}$ ceramic was fabricated by in-situ reaction sintering foam-gelcasting 

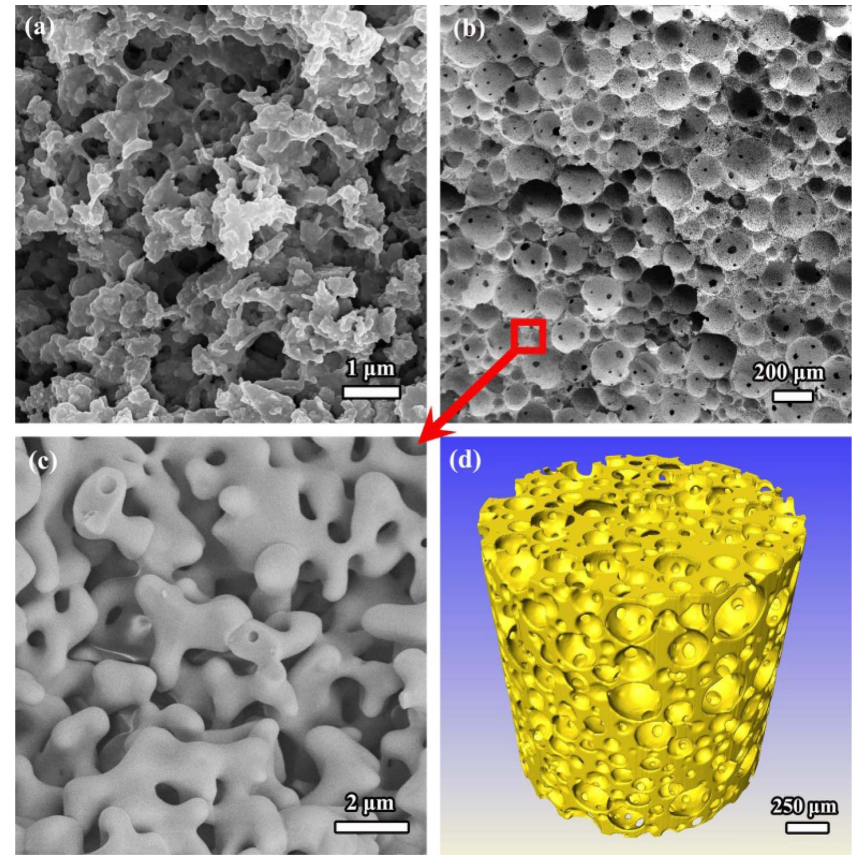

Fig. 24. Microstructure of the green body and the multiple porous structures of porous $\gamma-\mathrm{Y}_{2} \mathrm{Si}_{2} \mathrm{O}_{7}$ : (a) green body, (b) large pores, (c) small pores, and (d) X-ray tomography image of the large pores. Reproduced with permission from reference. ${ }^{40)}$

method by using $\mathrm{Y}_{2} \mathrm{O}_{3}$ and $\mathrm{SiO}_{2}$ powders as the raw materials and N-hydroxymethyl acrylamide as the monomer. ${ }^{40)} \mathrm{It}$ has been mentioned earlier that pure-phase $\gamma-\mathrm{Y}_{2} \mathrm{Si}_{2} \mathrm{O}_{7}$ is difficult to prepare. Hence, the focus should be on the phase composition of the porous sample obtained. From the XRD patterns of Fig. 23, it is noticed that there are three compositions in the sample when the sintering temperature is $1500^{\circ} \mathrm{C}$. It also proves that it is difficult to fabricate singlephase $\gamma-\mathrm{Y}_{2} \mathrm{Si}_{2} \mathrm{O}_{7}$ owing to the formation of apatite and other polymorphs. However, pure porous $\gamma-\mathrm{Y}_{2} \mathrm{Si}_{2} \mathrm{O}_{7}$ ceramic is successfully obtained when the green body is sintered at $1550^{\circ} \mathrm{C}$ when using $\mathrm{Y}_{2} \mathrm{O}_{3}$ and $\mathrm{SiO}_{2}$ powders as the starting materials.
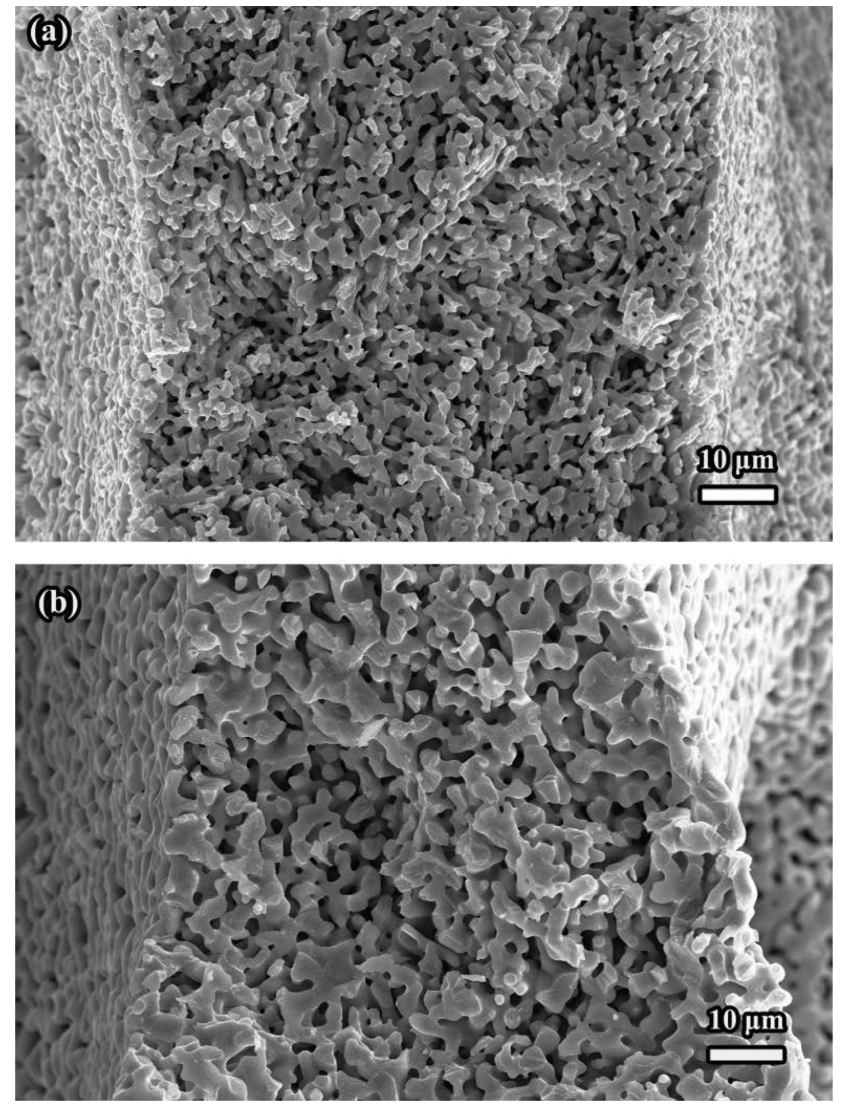

Fig. 25. Micrographs of the skeleton of porous $\gamma-\mathrm{Y}_{2} \mathrm{Si}_{2} \mathrm{O}_{7}$ ceramic synthesized by in-situ foam-gelcasting that were sintered at (a) $1650^{\circ} \mathrm{C}$ and (b) $1700^{\circ} \mathrm{C}$ for $2 \mathrm{~h}$. Reproduced with permission from reference. ${ }^{40)}$

Unlike the reticulated porous structure obtained through the polymeric sponge impregnation method, the porous $\gamma$ $\mathrm{Y}_{2} \mathrm{Si}_{2} \mathrm{O}_{7}$ synthesized by in-situ foam-gelcasting method has multiple pore structures (Fig. 24), which is similar to the porous $\mathrm{Y}_{2} \mathrm{SiO}_{5}$ ceramic prepared by the in-situ foam-gelcasting method. The multiple pore structures include both large pores $(60-250 \mu \mathrm{m})$ and small pores $(0.1-1.5 \mu \mathrm{m})$ in the skeleton, as well as windows $(10-40 \mu \mathrm{m})$ between the large
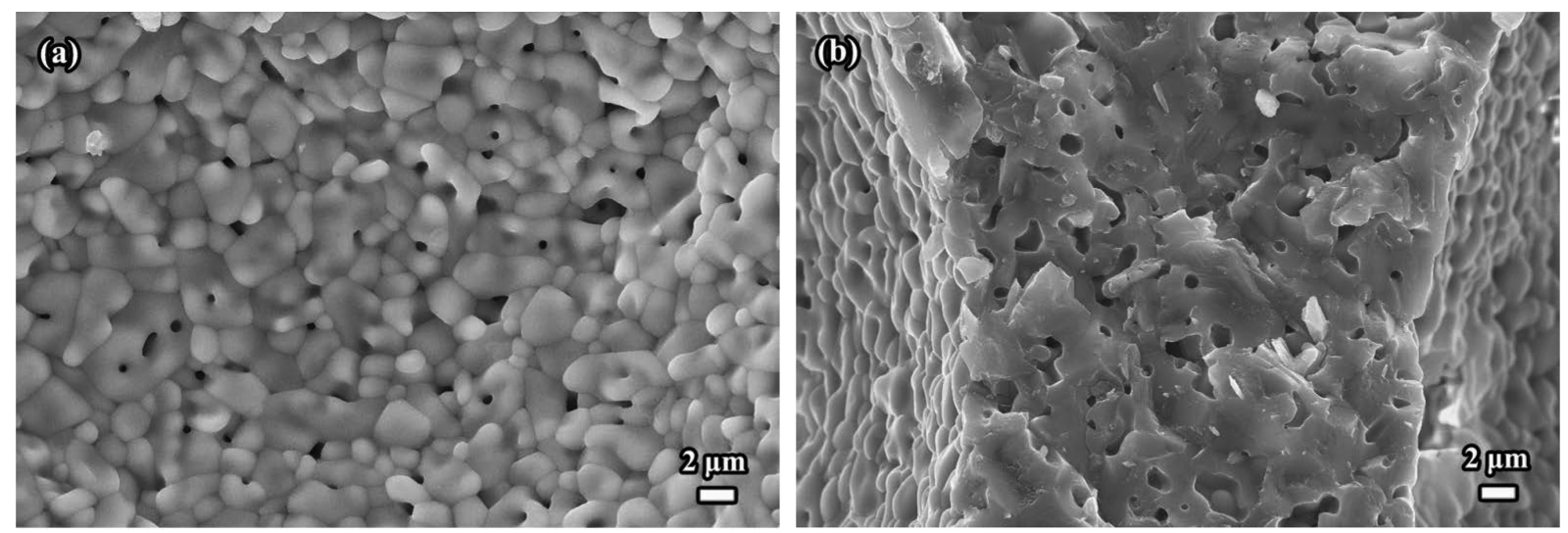

Fig. 26. SEM images of porous $\gamma-\mathrm{Y}_{2} \mathrm{Si}_{2} \mathrm{O}_{7}$ ceramic prepared by direct foam-gelcasting method by using $\mathrm{Y}_{2} \mathrm{Si}_{2} \mathrm{O}_{7}$ powder that was sintered at $1550^{\circ} \mathrm{C}$ for $2 \mathrm{~h}$ : (a) cell wall and (b) skeleton. 
pores. Although the size of the large pores is $60-250 \mu \mathrm{m}$ (which is still smaller than the $200-700 \mu \mathrm{m}$ for reticulated porous ceramic), the channels flowed through by the convective gas are the small pores $(0.1-1.5 \mu \mathrm{m})$ and the windows (10-40 $\mathrm{mm})$ during the heat conduction. Hence, the flow velocity of air would be much lower than that of the reticulated sample. Furthermore, there are plenty of interfaces that reflect and scatter infrared radiation to further reduce heat transport. Therefore, this type of structure can result in a distinctly better heat-shielding performance than that of the reticulated porous ceramic. The low thermal conductivity of $0.230 \mathrm{~W} /(\mathrm{m} \cdot \mathrm{K})$ for the porosity of $84.9 \%$ proves the eminent heat-shielding performance of the porous $\gamma-\mathrm{Y}_{2} \mathrm{Si}_{2} \mathrm{O}_{7}$ prepared by in-situ foam-gelcasting method. Furthermore, the results of low bulk density $\left(0.61 \mathrm{~g} / \mathrm{cm}^{3}\right)$, high compressive strength (6.22 $\mathrm{MPa}$ ), and low linear shrinkage (6.0\%) suggest that porous $\gamma-\mathrm{Y}_{2} \mathrm{Si}_{2} \mathrm{O}_{7}$ ceramic is a promising ther- mal insulator with excellent durability at high temperatures.

Herein, it is important to mention how the small pores are formed. Wu et al. pointed out that the basic reason for the formation of small pores is the in-situ reaction partial sintering process, rather than non-sintering densification, ${ }^{28,40,43)}$ which is similar to the mechanism of formation of the small pores of porous $\mathrm{Y}_{2} \mathrm{SiO}_{5}$ ceramic. Experimental results reveal that the small pores still maintain their porous morphology, even when the holding time is increased to $3-5 \mathrm{~h}$ or several reheating circulations are conducted (2-4 times, from $25^{\circ} \mathrm{C}$ to $1550^{\circ} \mathrm{C}$ for $2 \mathrm{~h}$ ). After the sample was sintered at $1650^{\circ} \mathrm{C}$ and $1700^{\circ} \mathrm{C}$ for $2 \mathrm{~h}$, the small pores still existed, as shown in Fig. 25. It indicates that the small pores generated by the in-situ reaction process are so stable that they could still exist even when the temperature is close to the melting point $\left(1775^{\circ} \mathrm{C}\right)$ of $\mathrm{Y}_{2} \mathrm{Si}_{2} \mathrm{O}_{7}$ ceramic.
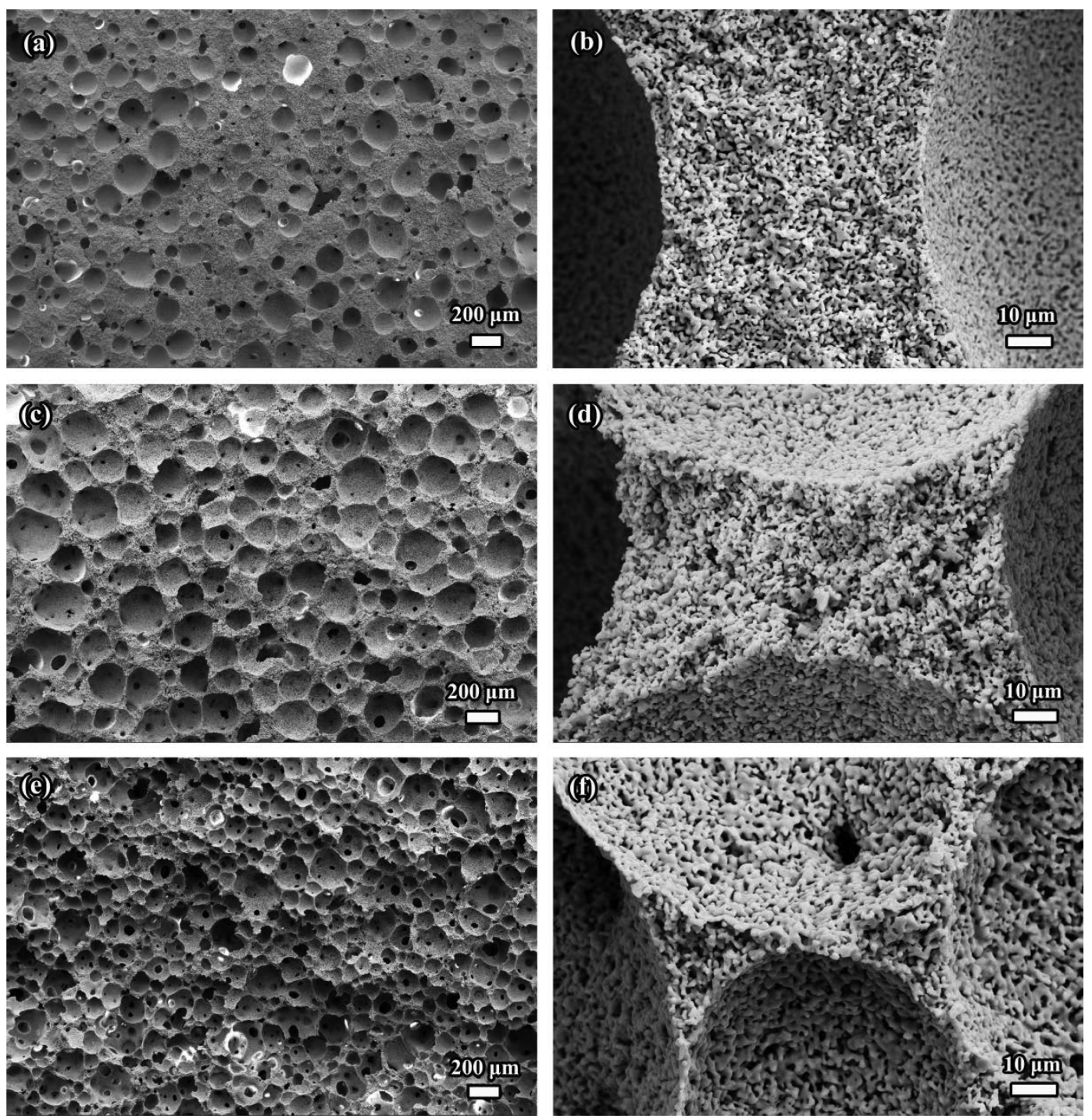

Fig. 27. SEM images of porous $\gamma-\mathrm{Y}_{2} \mathrm{Si}_{2} \mathrm{O}_{7}$ ceramic with different porosities fabricated by in-situ foam-gelcasting method by using gelatin as the gel former: (a) and (b) show the large and small pores, respectively, for $64.3 \%$ porosity; (c) and (d) are the corresponding micrographs for $77.2 \%$ porosity; and (e) and (f) are the corresponding micrographs for $88.2 \%$ porosity. Reproduced with permission from reference. ${ }^{102)}$ 

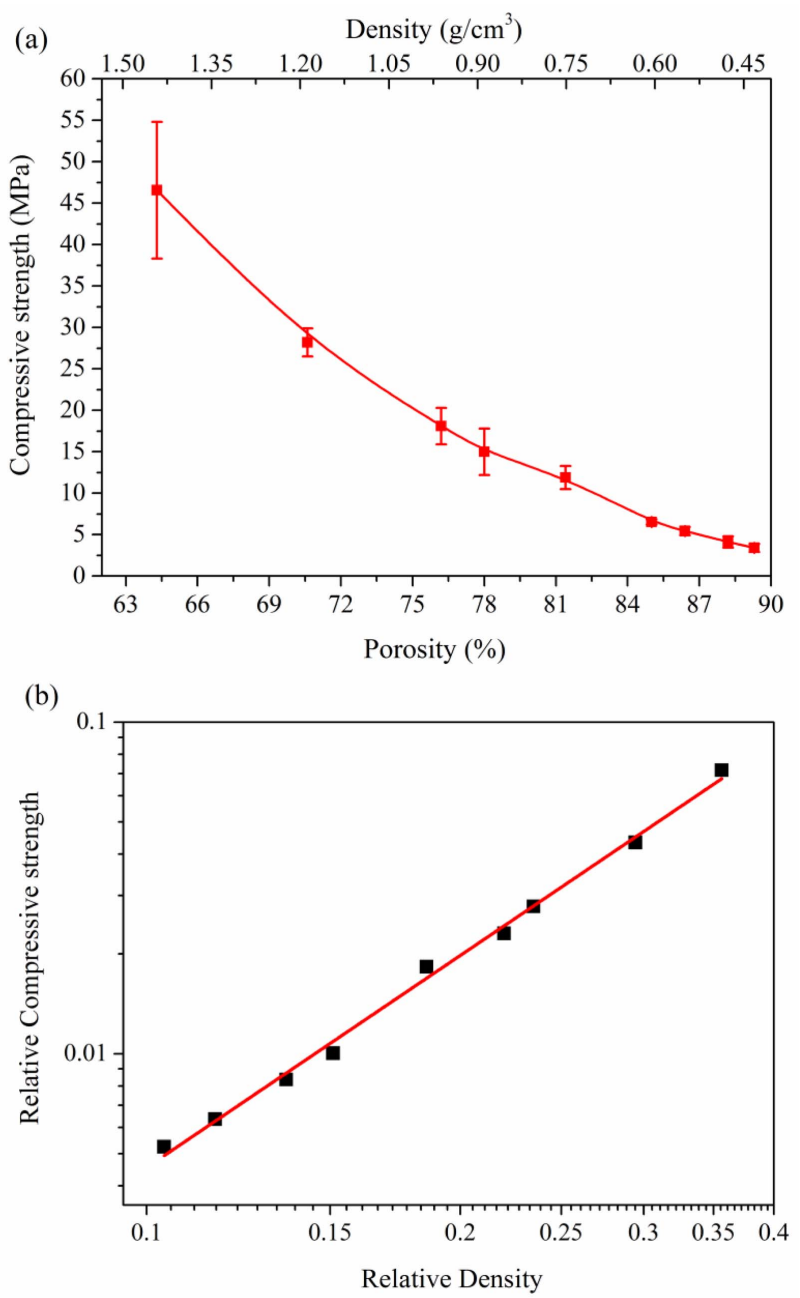

Fig. 28. (a) Compressive strength of porous $\gamma-\mathrm{Y}_{2} \mathrm{Si}_{2} \mathrm{O}_{7}$ ceramic at different porosities; and (b) relative compressive strength as a function of relative density of porous $\gamma-\mathrm{Y}_{2} \mathrm{Si}_{2} \mathrm{O}_{7}$. Reproduced with permission from reference. ${ }^{102)}$

Besides, $\mathrm{Y}_{2} \mathrm{Si}_{2} \mathrm{O}_{7}$ powder is used to prepare porous $\gamma-\mathrm{Y}_{2} \mathrm{Si}_{2} \mathrm{O}_{7}$ ceramic by foam-gelcasting method after sintering at $1550^{\circ} \mathrm{C}$ for $2 \mathrm{~h}$. However, the cell wall and the skeleton of the obtained sample are nearly dense (Fig. 26), particularly the cell wall. In short, the small pores are formed by in-situ reaction partial sintering and are quite stable.

Owing to the toxicity and pungent odor of the monomer (acrylamide), cross-linker (N,N'-methylenebisacrylamide), catalyst (N,N,N',N'-tetramethylethylenediamine), and initiator (ammonium persulfate), gelatin, as a natural and environmentally friendly gelling agent, was chosen to replace the above four compounds for the preparation of porous $\gamma$ $\mathrm{Y}_{2} \mathrm{Si}_{2} \mathrm{O}_{7}$ ceramic. ${ }^{102)}$ Additionally, the effect of the change in gel former on the structure is negligible, and the as-prepared porous $\gamma-\mathrm{Y}_{2} \mathrm{Si}_{2} \mathrm{O}_{7}$ ceramic also exhibits a similar multiple pore structure. The factor that influences the microstructure is the porosity. Specifically, the cell wall is relatively thick and more small pores exist in the sample with

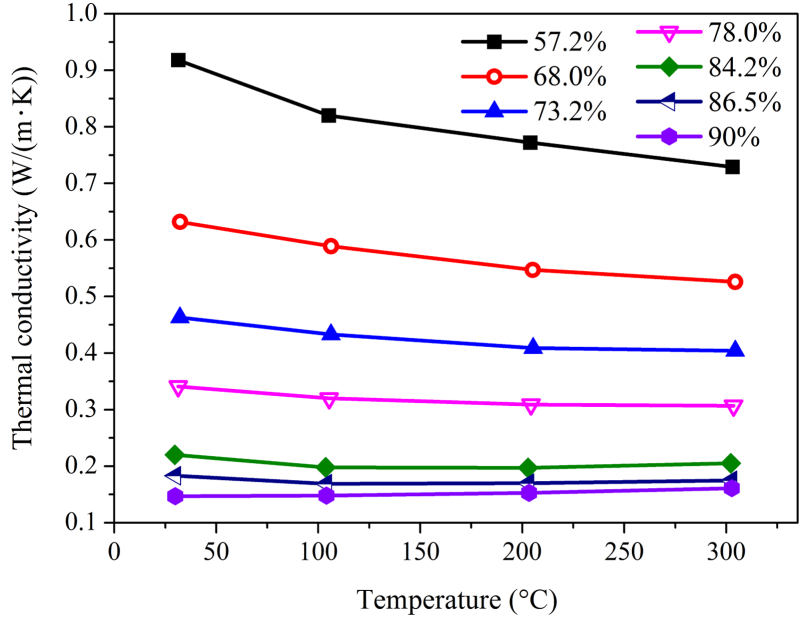

Fig. 29. Variation in the thermal conductivity of porous $\gamma$ $\mathrm{Y}_{2} \mathrm{Si}_{2} \mathrm{O}_{7}$ ceramic with different porosities between room temperature and $300^{\circ} \mathrm{C}$. Reproduced with permission from reference. ${ }^{102)}$

low porosity. On the other hand, the pore wall is very thin and more large pores are observed in the sample with high porosity (Fig. 27).

As for the porosity, it not only affects the microstructure of a sample, but also determines the properties of a porous sample. When the porosity of porous $\gamma-\mathrm{Y}_{2} \mathrm{Si}_{2} \mathrm{O}_{7}$ ceramic increases from $64.3 \%$ to $89.3 \%$, the density correspondingly ranges from $1.44 \mathrm{~g} / \mathrm{cm}^{3}$ to $0.42 \mathrm{~g} / \mathrm{cm}^{3}$, and the strength of the sample decreases from $46.5 \mathrm{MPa}$ to $3.4 \mathrm{MPa}$, as shown in Fig. 28(a). On the basis of the Gibson and Ashby theory, the relative compressive strength of a porous material is related to the relative density as follows: $:^{78)}$

$$
\frac{\sigma}{\sigma_{s}}=C\left(\frac{\rho}{\rho_{s}}\right)^{n}
$$

where $\sigma$ and $\rho$ are the compressive strength and bulk den-

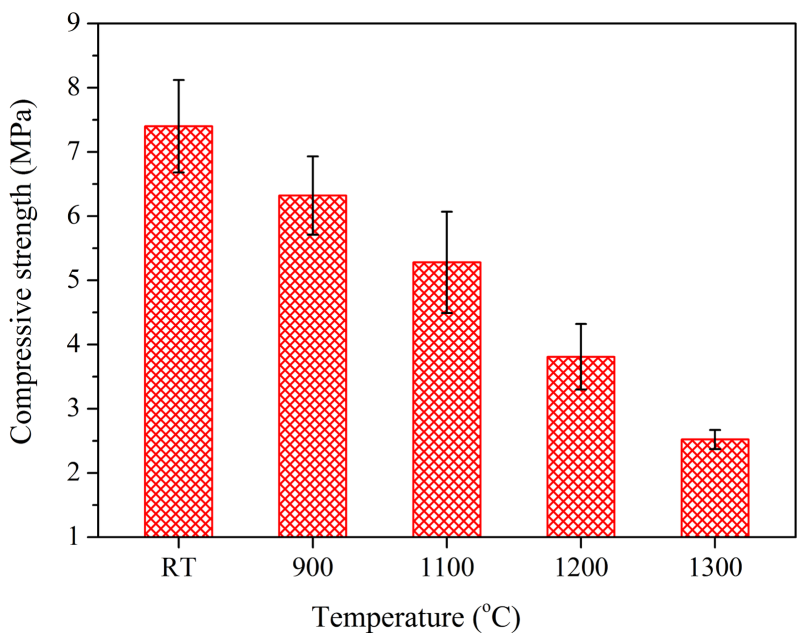

Fig. 30. High-temperature compressive strength of a porous $\gamma-\mathrm{Y}_{2} \mathrm{Si}_{2} \mathrm{O}_{7}$ sample with the porosity of $82.5 \%$ between $900^{\circ} \mathrm{C}$ and $1300^{\circ} \mathrm{C}$. Reproduced with permission from reference. ${ }^{102)}$ 
Table 6. Properties of the Original Sample Sintered from the Green Body and the Changes in the Properties of Porous $\gamma-\mathrm{Y}_{2} \mathrm{Si}_{2} \mathrm{O}_{7}$ after the 1st and 2nd Heating Circulations (from Room Temperature to $1550^{\circ} \mathrm{C}$ at the Heating Rate of $5^{\circ} \mathrm{C} / \mathrm{min}$ and Holding for $2 \mathrm{~h}$ ). Reproduced with permission from reference ${ }^{102)}$

\begin{tabular}{cccccc}
\hline $\begin{array}{c}\text { Reheating } \\
\text { circulation }\end{array}$ & $\begin{array}{c}\text { Shrinkage } \\
(\%)\end{array}$ & $\begin{array}{c}\text { Bulk density } \\
\left(\mathrm{g} / \mathrm{cm}^{3}\right)\end{array}$ & $\begin{array}{c}\text { Porosity } \\
(\%)\end{array}$ & $\begin{array}{c}\text { Compressive strength } \\
(\mathrm{MPa})\end{array}$ & $\begin{array}{c}\text { Specific strength } \\
\left(10^{-3} \mathrm{Nm} / \mathrm{kg}\right)\end{array}$ \\
\hline Original & $/$ & 0.71 & 82.5 & 7.4 & 10.4 \\
1 & $1.3 \pm 0.1$ & $0.74 \pm 0.01$ & $81.7 \pm 0.2$ & $9.7 \pm 1.1$ & 13.1 \\
2 & $1.7 \pm 0.4$ & $0.78 \pm 0.01$ & $80.7 \pm 0.2$ & $12.7 \pm 3.3$ & 18.3 \\
\hline
\end{tabular}

sity of a porous ceramic, respectively; $\sigma_{s}$ and $\rho_{s}$ are the compressive strength and density of the corresponding dense ceramic, which are $650 \mathrm{MPa}$ and $4.04 \mathrm{~g} / \mathrm{cm}^{3}$ for $\gamma-\mathrm{Y}_{2} \mathrm{Si}_{2} \mathrm{O}_{7}$, respectively; ${ }^{59,94)}$ and $C$ and $n$ are constants. The slope (n) was fitted to be 2.12 in the double log plot for the as-prepared porous $\gamma-\mathrm{Y}_{2} \mathrm{Si}_{2} \mathrm{O}_{7}$ (shown in Fig. 28(b)). Although the value is similar to 2.22 , for porous $\mathrm{SiOC}$ ceramic, ${ }^{107)}$ and 2.3 , for porous $\mathrm{Al}_{2} \mathrm{O}_{3}$ ceramic, ${ }^{99)}$ the theoretical value is 1.5 , according to the Gibson and Ashby model. The lower the value $(\geq 1.5)$ of $n$, the better. It indicates that the porous material would have a higher mechanical strength when the value of $\mathrm{n}$ is close to 1.5.

Moreover, the influence of porosity on the thermal conductivity of porous $\gamma-\mathrm{Y}_{2} \mathrm{Si}_{2} \mathrm{O}_{7}$ is shown in Fig. 29. Porous $\gamma$ $\mathrm{Y}_{2} \mathrm{Si}_{2} \mathrm{O}_{7}$ ceramic has the advantage of low thermal conductivities, such as $0.147-0.918 \mathrm{~W} /(\mathrm{m} \cdot \mathrm{K})$ at $30^{\circ} \mathrm{C}$ and $0.161-$ $0.729 \mathrm{~W} /(\mathrm{m} \cdot \mathrm{K})$ at $300^{\circ} \mathrm{C}$, which correspond to the porosities of $90.0 \%-57.2 \%$. As can be seen, the porous $\gamma-\mathrm{Y}_{2} \mathrm{Si}_{2} \mathrm{O}_{7}$ ceramic prepared by in-situ foam-gelcasting method has quite a low thermal conductivity, especially for a high porosity. This is due to the fact that, on one hand, dense $\gamma-\mathrm{Y}_{2} \mathrm{Si}_{2} \mathrm{O}_{7}$ itself has a lower thermal conductivity than certain low thermal conductivity ceramics. On the other hand, the high porosity and small pores in the skeleton remarkably restrain heat transmission and reduce the thermal conductivity.

As a new-generation high-temperature thermal insulation material, its high-temperature performance should be investigated. For example, the high-temperature strength and high-temperature stability are of great importance to a high-temperature thermal insulator. Based on research, it has been found that the compressive strength of porous $\gamma$ $\mathrm{Y}_{2} \mathrm{Si}_{2} \mathrm{O}_{7}$ ceramic decreases as the temperature increases, as indicated in Fig. 30. Specifically, at the temperatures of $900^{\circ} \mathrm{C}$ and $1100^{\circ} \mathrm{C}$, the strengths are maintained at above $85 \%$ and $71 \%$, respectively, of that at room temperature $(7.4$ $\mathrm{MPa}$ ).

As for the high-temperature stability, it is investigated by examining the influence of heating circulation on the properties of porous $\gamma-\mathrm{Y}_{2} \mathrm{Si}_{2} \mathrm{O}_{7}$ ceramic. The porous sample was heated from room temperature to $1550^{\circ} \mathrm{C}$ and held for $2 \mathrm{~h}$ for every cycle. The heating-circulation shrinkages after the first and second cycles are only $1.3 \%$ and $1.7 \%$ (Table 6), respectively. Furthermore, the changes in density and porosity after every cycle are also very small, being $0.03 \mathrm{~g} /$ $\mathrm{cm}^{3}$ and $0.04 \mathrm{~g} / \mathrm{cm}^{3}$ and $0.8 \%$ and $1.0 \%$, respectively. Only small decreases in the density and porosity are noticed, while a remarkable increase in the strength is observed. Thus, the porous $\gamma-\mathrm{Y}_{2} \mathrm{Si}_{2} \mathrm{O}_{7}$ ceramic fabricated by in-situ foam-gelcasting method with good high-temperature performance is highly promising for application as a high-temperature thermal insulation material.

\subsubsection{Porous $\gamma-\left(\mathrm{Y}_{1-\mathrm{x}} \mathrm{Ho}_{\mathrm{x}}\right)_{2} \mathrm{Si}_{2} \mathrm{O}_{7}$ solid solution}

As noted above, porous $\gamma-\mathrm{Y}_{2} \mathrm{Si}_{2} \mathrm{O}_{7}$ ceramic prepared by insitu foam-gelcasting method is a promising high-temperature thermal insulator. However, the good strength could only be maintained up to the temperature of $1100^{\circ} \mathrm{C}$. The high-temperature strength retention is very low, when the temperature is higher than $1100^{\circ} \mathrm{C}$. For example, the compressive strength $(2.5 \mathrm{MPa})$ of porous $\gamma-\mathrm{Y}_{2} \mathrm{Si}_{2} \mathrm{O}_{7}$ at $1300^{\circ} \mathrm{C}$ decreases to $34 \%$ of that at room temperature $(7.4 \mathrm{MPa}){ }^{102)}$ Hence, it is necessary to enhance the high-temperature strength of the porous $\gamma-\mathrm{Y}_{2} \mathrm{Si}_{2} \mathrm{O}_{7}$ ceramic. As is known, solution strengthening is an effective method to increase the mechanical properties of ceramic materials. ${ }^{65-67)}$ Addition-
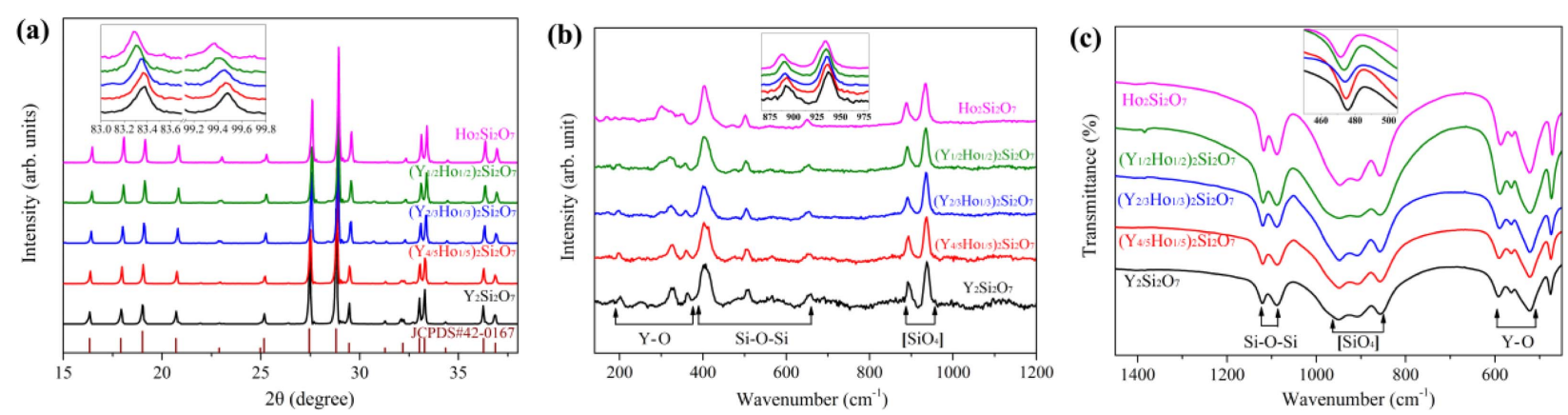

Fig. 31. X-ray diffraction patterns, Raman spectra, and FTIR spectra of porous $\gamma-\left(\mathrm{Y}_{1-\mathrm{x}} \mathrm{Ho}_{\mathrm{x}}\right)_{2} \mathrm{Si}_{2} \mathrm{O}_{7}$ ceramic sintered at $1550^{\circ} \mathrm{C}$ for 2 $\mathrm{h}\left(\gamma-\left(\mathrm{Y}_{1-\mathrm{x}} \mathrm{Ho}_{\mathrm{x}}\right)_{2} \mathrm{Si}_{2} \mathrm{O}_{7}\right.$ is written as $\left(\mathrm{Y}_{1-\mathrm{x}} \mathrm{Ho}_{\mathrm{x}}\right)_{2} \mathrm{Si}_{2} \mathrm{O}_{7}$ for brevity in the figures). Reproduced with permission from reference. ${ }^{43)}$ 

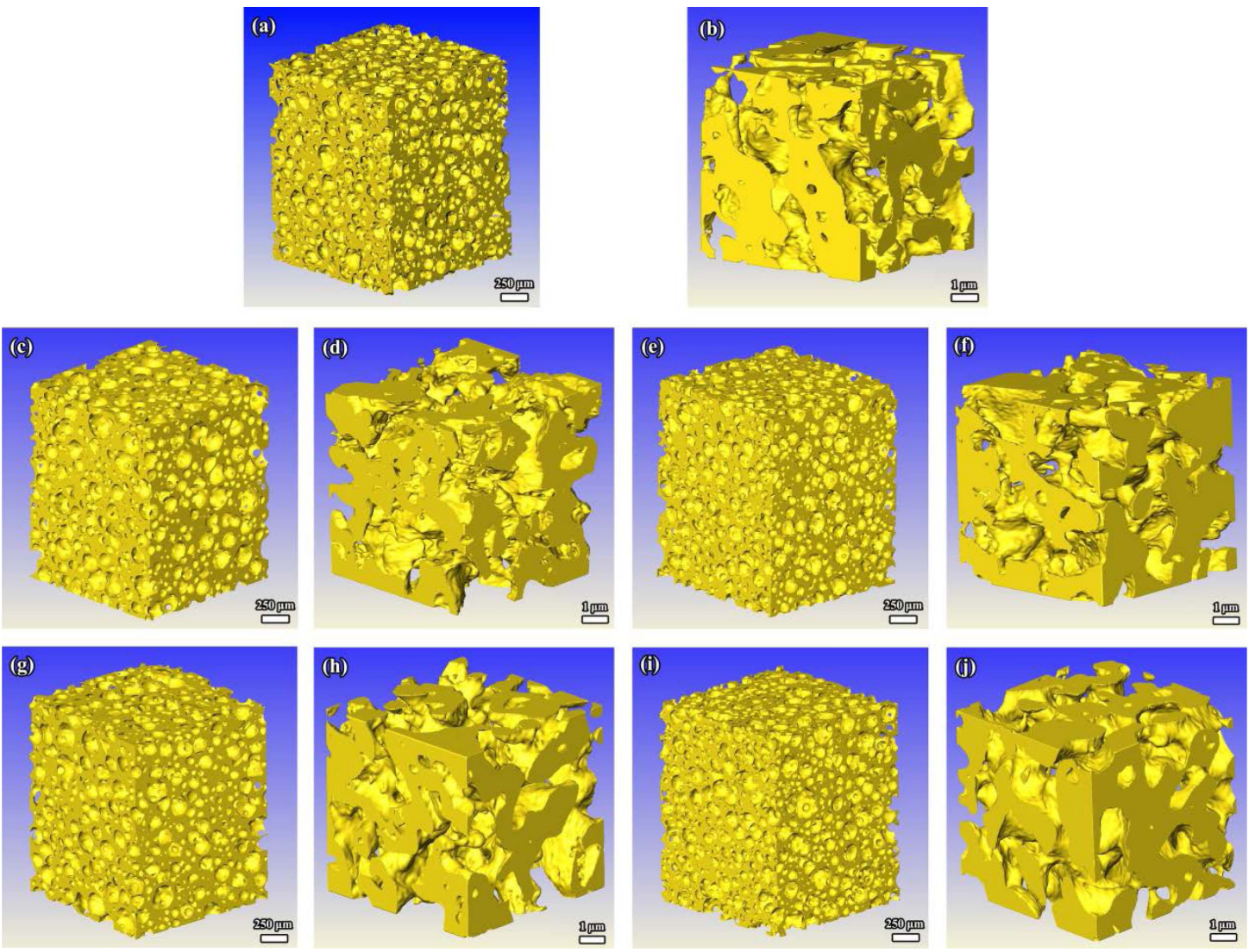

Fig. 32. XRT micrographs of porous $\gamma-\left(\mathrm{Y}_{1-\mathrm{x}} \mathrm{Ho}_{\mathrm{x}}\right)_{2} \mathrm{Si}_{2} \mathrm{O}_{7}$ ceramic: (a) and (b) are the large and small pores, respectively, of porous $\mathrm{Y}_{2} \mathrm{Si}_{2} \mathrm{O}_{7}$; (c) and (d) are the corresponding images of $\left(\mathrm{Y}_{4 / 5} \mathrm{Ho}_{1 / 5}\right)_{2} \mathrm{Si}_{2} \mathrm{O}_{7}$; (e) and (f) are the corresponding images of $\left(\mathrm{Y}_{2 / 3} \mathrm{Ho}_{1 / 3}\right)_{2} \mathrm{Si}_{2} \mathrm{O}_{7} ;(\mathrm{g})$ and $(\mathrm{h})$ are the corresponding images of $\left(\mathrm{Y}_{1 / 2} \mathrm{Ho}_{1 / 2}\right)_{2} \mathrm{Si}_{2} \mathrm{O}_{7}$; and (i) and (j) are the corresponding images of $\mathrm{Ho}_{2} \mathrm{Si}_{2} \mathrm{O}_{7}$. Reproduced with permission from reference. ${ }^{43)}$

ally, Tian et al. found that $\mathrm{Ho}_{2} \mathrm{SiO}_{5}$ exhibits a higher flexural strength than any other $\mathrm{RE}_{2} \mathrm{SiO}_{5},{ }^{24)}$ and the flexural strength at high temperatures is higher than that at room temperature, as revealed in subsequent studies. Therefore, Wu et al. employed solid solution strengthening with Ho to improve the properties of porous $\gamma-\mathrm{Y}_{2} \mathrm{Si}_{2} \mathrm{O}_{7}$ ceramic at high temperatures. ${ }^{43)}$

Porous $\gamma-\left(\mathrm{Y}_{1-\mathrm{x}} \mathrm{Ho}_{\mathrm{x}}\right)_{2} \mathrm{Si}_{2} \mathrm{O}_{7}$ ceramic was fabricated by in-situ foam-gelcasting method by using $\mathrm{Y}_{2} \mathrm{O}_{3}, \mathrm{Ho}_{2} \mathrm{O}_{3}$, and $\mathrm{SiO}_{2}$ powders as the starting materials. First, it should be confirmed whether the as-prepared porous sample is solid solution. Hence, the phase composition and chemical bonding of the samples need to be examined. Fig. 31 shows the X-ray diffraction patterns, Raman spectra, and FTIR spectra of porous $\gamma-\left(\mathrm{Y}_{1-\mathrm{x}} \mathrm{Ho}_{\mathrm{x}}\right)_{2} \mathrm{Si}_{2} \mathrm{O}_{7}$ ceramic. From the figure, it is observed that all the samples display nearly the same peak patterns for the three characterization methods. As shown in the insets of the three figures, the diffraction peaks (peak positions) shift towards lower angles (lower wavenumber ranges) with the increase in Ho content. It indicates that $\mathrm{Ho}^{3+}$ is doped into the crystal lattice of $\gamma-\mathrm{Y}_{2} \mathrm{Si}_{2} \mathrm{O}_{7}$, and the shift is caused by the fact that the ionic radius $(0.894 \AA)$ of $\mathrm{Ho}^{3+}$ is larger than that $(0.880 \AA)$ of $\mathrm{Y}^{3+}$. Consequently, porous $\gamma-\left(\mathrm{Y}_{1-\mathrm{x}} \mathrm{Ho}_{\mathrm{x}}\right)_{2} \mathrm{Si}_{2} \mathrm{O}_{7}$ solid solution was successfully fabricated.

Similar to the microstructure of the porous $\gamma-\mathrm{Y}_{2} \mathrm{Si}_{2} \mathrm{O}_{7}$

Table 7. Characteristics of Porous $\gamma-\left(\mathrm{Y}_{1-\mathrm{x}} \mathrm{Ho}_{\mathrm{x}}\right)_{2} \mathrm{Si}_{2} \mathrm{O}_{7}$ Ceramics, based on XRT Technology. Reproduced with permission from reference ${ }^{43)}$

\begin{tabular}{cccccc}
\hline Porous ceramic & $\begin{array}{c}\text { Porosity } \\
(\%)\end{array}$ & $\begin{array}{c}\text { Volume fraction of } \\
\text { large pores (\%) }\end{array}$ & $\begin{array}{c}\text { Proportion of large } \\
\text { pores (\%) }\end{array}$ & $\begin{array}{c}\text { Proportion of small } \\
\text { pores (\%) }\end{array}$ & $\begin{array}{c}\text { Porosity of skeleton } \\
(\%)\end{array}$ \\
\hline $\mathrm{Y}_{2} \mathrm{Si}_{2} \mathrm{O}_{7}$ & 80.2 & 58.2 & 72.6 & 27.4 & 52.7 \\
$\left(\mathrm{Y}_{4 / 5} \mathrm{Ho}_{1 / 5}\right)_{2} \mathrm{Si}_{2} \mathrm{O}_{7}$ & 80.6 & 55.9 & 69.4 & 30.6 & 56.1 \\
$\left(\mathrm{Y}_{2 / 3} \mathrm{Ho}_{1 / 3}\right)_{2} \mathrm{Si}_{2} \mathrm{O}_{7}$ & 79.6 & 56.1 & 69.6 & 30.4 & 54.3 \\
$\left(\mathrm{Y}_{1 / 2} \mathrm{Ho}_{1 / 2}\right)_{2} \mathrm{Si}_{2} \mathrm{O}_{7}$ & 79.7 & 55.1 & 69.1 & 30.9 & 54.8 \\
$\mathrm{Ho}_{2} \mathrm{Si}_{2} \mathrm{O}_{7}$ & 79.3 & 60.2 & 76.1 & 23.9 & 47.6 \\
\hline
\end{tabular}


Table 8. Comparisons of the Porosity, Density, Shrinkage, and Strength of Porous $\left(\mathrm{Y}_{1-\mathrm{x}} \mathrm{Ho}_{\mathrm{x}}\right)_{2} \mathrm{Si}_{2} \mathrm{O}_{7}$ Thermal Insulators. Reproduced with permission from reference ${ }^{43)}$

\begin{tabular}{cccccc}
\hline Porous ceramic & Porosity (\%) & $\begin{array}{c}\text { Density } \\
\left(\mathrm{g} / \mathrm{cm}^{3}\right)\end{array}$ & Shrinkage (\%) & $\begin{array}{c}\text { Compressive strength } \\
(\mathrm{MPa})\end{array}$ & $\begin{array}{c}\text { Specific strength } \\
\left(10^{3} \mathrm{Nm} / \mathrm{kg}\right)\end{array}$ \\
\hline $\mathrm{Y}_{2} \mathrm{Si}_{2} \mathrm{O}_{7}$ & $81.2 \pm 0.1$ & $0.76 \pm 0.01$ & $4.7 \pm 0.1$ & $12.0 \pm 1.9$ & 15.7 \\
$\left(\mathrm{Y}_{4 / 5} \mathrm{Ho}_{1 / 5}\right)_{2} \mathrm{Si}_{2} \mathrm{O}_{7}$ & $80.9 \pm 0.1$ & $0.83 \pm 0.01$ & $5.3 \pm 0.1$ & $11.0 \pm 1.9$ & 13.2 \\
$\left(\mathrm{Y}_{2 / 3} \mathrm{Ho}_{1 / 3}\right)_{2} \mathrm{Si}_{2} \mathrm{O}_{7}$ & $79.3 \pm 0.2$ & $0.94 \pm 0.01$ & $7.2 \pm 0.2$ & $13.9 \pm 1.1$ & 14.7 \\
$\left(\mathrm{Y}_{1 / 2} \mathrm{Ho}_{1 / 2}\right)_{2} \mathrm{Si}_{2} \mathrm{O}_{7}$ & $80.0 \pm 0.2$ & $0.98 \pm 0.01$ & $7.2 \pm 0.1$ & $11.7 \pm 2.3$ & 11.9 \\
$\mathrm{Ho}_{2} \mathrm{Si}_{2} \mathrm{O}_{7}$ & $78.3 \pm 0.1$ & $1.24 \pm 0.01$ & $10.2 \pm 0.5$ & $11.5 \pm 1.0$ & 9.30 \\
\hline
\end{tabular}

ceramic prepared by in-situ foam-gelcasting, the porous $\gamma$ $\left(\mathrm{Y}_{1-\mathrm{x}} \mathrm{Ho}_{\mathrm{x}}\right)_{2} \mathrm{Si}_{2} \mathrm{O}_{7}$ solid solution also exhibits multiple pore structures, as indicated in Fig. 32. From the XRT images, it is observed that the porous sample consists of open large pores $(30-300 \mu \mathrm{m})$ that are nearly spherical in shape and interconnected by small pores $(0.1-3.5 \mu \mathrm{m})$ in the skeleton and the circular window between the large pores. The reason for the similarity in the structures of the porous $\gamma$ $\left(\mathrm{Y}_{1-\mathrm{x}} \mathrm{Ho}_{\mathrm{x}}\right)_{2} \mathrm{Si}_{2} \mathrm{O}_{7}$ is that the solid content, preparation technol-

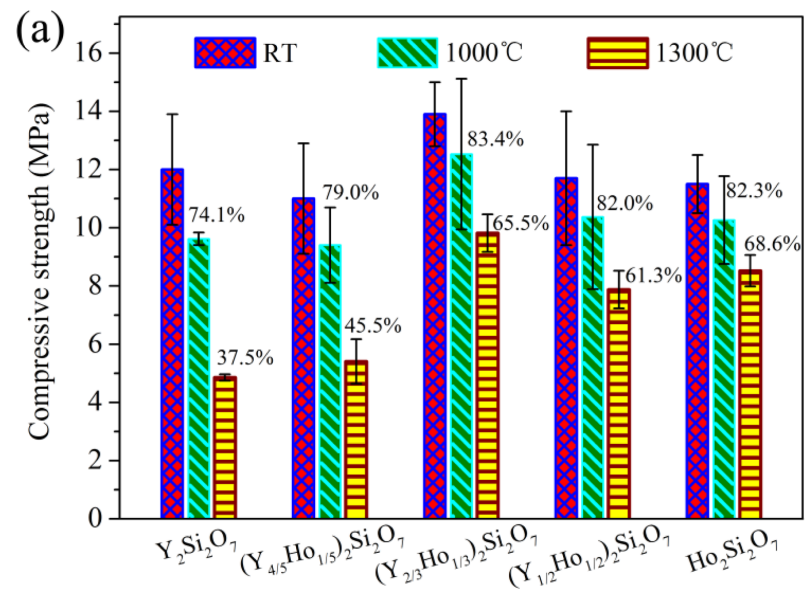

(b)

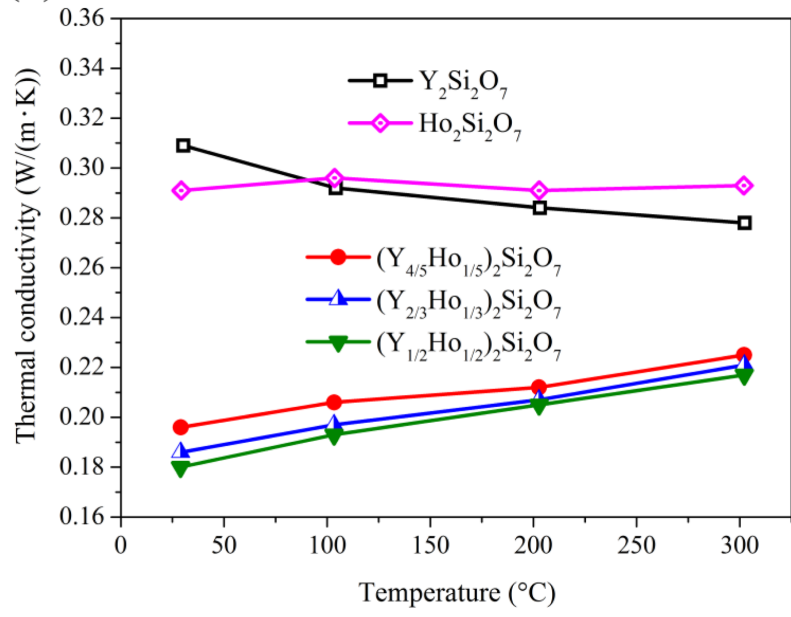

Fig. 33. (a) High-temperature compressive strengths and (b) thermal conductivities of porous $\left(\mathrm{Y}_{1-\mathrm{x}} \mathrm{Ho}_{\mathrm{x}}\right)_{2} \mathrm{Si}_{2} \mathrm{O}_{7} \mathrm{sam}-$ ples. Reproduced with permission from reference. ${ }^{43)}$ ogy, and reaction mode are the same for the samples. Therefore, there is little divergence in the structures and pore size distributions of the porous samples.

Besides, porosity characteristics of porous $\gamma-\left(\mathrm{Y}_{1-\mathrm{x}} \mathrm{Ho}_{\mathrm{x}}\right)_{2} \mathrm{Si}_{2} \mathrm{O}_{7}$ could also be revealed through the XRT technology. In Table 7 , we can see that, under the condition of similar porosities $(\sim 80 \%)$, porous $\gamma-\mathrm{Y}_{2} \mathrm{Si}_{2} \mathrm{O}_{7}$ and $\gamma-\mathrm{Ho}_{2} \mathrm{Si}_{2} \mathrm{O}_{7}$ contain more large pores than the other three samples. Accordingly, the proportion of small pores and the porosity of the skeleton for solid solution are higher than those of porous $\gamma-\mathrm{Y}_{2} \mathrm{Si}_{2} \mathrm{O}_{7}$ and $\gamma-\mathrm{Ho}_{2} \mathrm{Si}_{2} \mathrm{O}_{7}$. A possible reason for such a phenomenon is that atomic diffusion in the solid solution is relatively slower and more difficult than in the pure samples. As a result, there are more interspaces between the grains of the solid solution samples.

On one hand, the room temperature properties need to be investigated. With the increase in the content of Ho, both the density and the shrinkage of the porous sample increase under the condition of similar porosity (Table 8). Nevertheless, the compressive strength of the porous ceramic is kept at a close value (about $12 \mathrm{MPa}$ ). Overall, the porous sample still exhibits good performance at room temperature after $\mathrm{Ho}$ is added. On the other hand, the high-temperature mechanical properties of the sample are the focus of attention of this research in order to verify whether the solid solution is effective in enhancing the high-temperature strength of porous $\gamma-\mathrm{Y}_{2} \mathrm{Si}_{2} \mathrm{O}_{7}$ ceramic. First, porous $\gamma-\mathrm{Ho}_{2}$ $\mathrm{Si}_{2} \mathrm{O}_{7}$ exhibits very good mechanical properties at high temperatures, compared to porous $\gamma-\mathrm{Y}_{2} \mathrm{Si}_{2} \mathrm{O}_{7}$. The strength retention at $1300^{\circ} \mathrm{C}$ is $68.6 \%$ of that at room temperature, which is distinctly superior to the $37.5 \%$ of the porous $\gamma$ $\mathrm{Y}_{2} \mathrm{Si}_{2} \mathrm{O}_{7}$ ceramic, as shown in Fig. 33(a). It indicates that the choice of Ho element is correct. Secondly, for the solid solution porous sample, the high-temperature strength is significantly enhanced after the addition of Ho. In particular, porous $\gamma-\left(\mathrm{Y}_{2 / 3} \mathrm{Ho}_{1 / 3}\right)_{2} \mathrm{Si}_{2} \mathrm{O}_{7}$ ceramic reveals the optimal reinforcement effect. The strength retentions are $83.4 \%$ and $65.5 \%$ (relative to the room temperature value) at $1000^{\circ} \mathrm{C}$ and $1300^{\circ} \mathrm{C}$, respectively. As a result, the high-temperature strength of porous $\gamma-\mathrm{Y}_{2} \mathrm{Si}_{2} \mathrm{O}_{7}$ ceramic is effectively improved by the method of solution strengthening with Ho.

Experiments have revealed that the solid solution strengthening evidently influences not only the high-temperature strength but also the thermal conductivity. As 


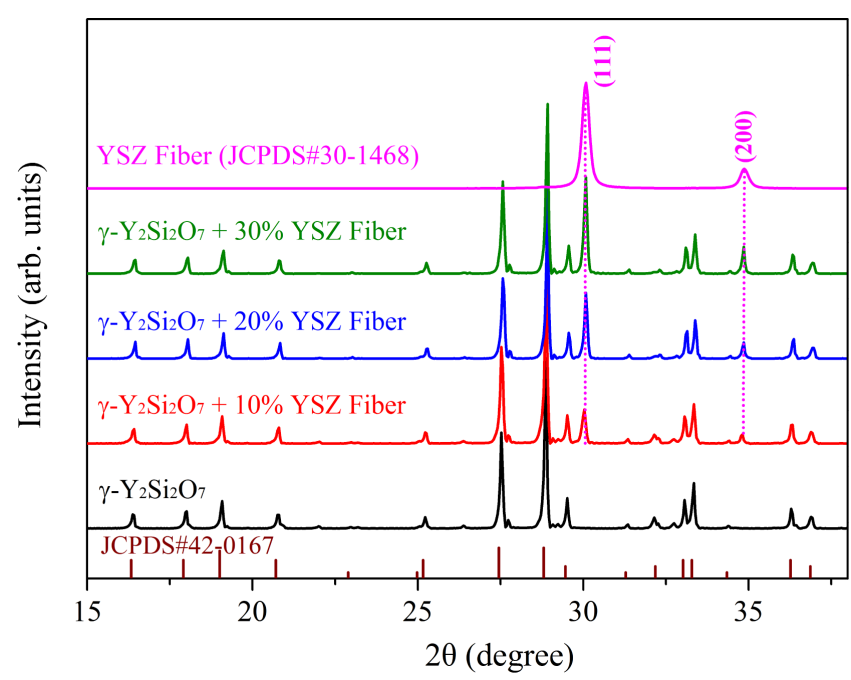

Fig. 34. XRD patterns of YSZ fiber-reinforced porous $\gamma$ $\mathrm{Y}_{2} \mathrm{Si}_{2} \mathrm{O}_{7}$ ceramics sintered at $1550^{\circ} \mathrm{C}$ for $2 \mathrm{~h}$ and the starting YSZ fiber $\left(\mathrm{ZrO}_{2}-15\right.$ wt.\% $\left.\mathrm{Y}_{2} \mathrm{O}_{3}\right)$. Reproduced with permission from reference. ${ }^{30)}$

shown in Fig. 33(b), the thermal conductivity of porous $\gamma$ $\mathrm{Y}_{2} \mathrm{Si}_{2} \mathrm{O}_{7}$ is close to that of porous $\gamma-\mathrm{Ho}_{2} \mathrm{Si}_{2} \mathrm{O}_{7}$. Surprisingly, the porous solid solution has a much lower thermal conductivity than the two single-component samples. This is because the solid solution sample contains more small pores (Table 7), which could inhibit heat conduction. ${ }^{75)}$ Besides, as for the components, the solid solution would result in lattice distortion and reduce heat conduction through intense phonon scattering. ${ }^{63,64)}$ The results suggest that the solid solution can increase the high-temperature strength and reduce the thermal conductivity of porous $\gamma-\mathrm{Y}_{2} \mathrm{Si}_{2} \mathrm{O}_{7}$ ceramic. Therefore, porous $\gamma-\left(\mathrm{Y}_{1-\mathrm{x}} \mathrm{Ho}_{\mathrm{x}}\right)_{2} \mathrm{Si}_{2} \mathrm{O}_{7}$ solid solution has great potential as a high-temperature thermal insulation material.

\subsubsection{Fiber-reinforced highly porous $\gamma-\mathrm{Y}_{2} \mathrm{Si}_{2} \mathrm{O}_{7}$ ceramic}

In general, high porosity is of great importance to a thermal insulation material. A higher porosity implies lower weight and lower thermal conductivity, as previously mentioned. Such a thermal insulator would exhibit a better heat insulation effect. Not only the porous $\mathrm{Y}_{2} \mathrm{SiO}_{5}$ ceramic, but also the porous $\gamma-\mathrm{Y}_{2} \mathrm{Si}_{2} \mathrm{O}_{7}$ ceramic requires superhigh porosity. However, based on the Ryshkewitch empirical formula, the strength of a porous ceramic decreases exponentially with the increase in the porosity of a sample: ${ }^{79)}$

$$
\sigma=\sigma_{0} e^{-B P}
$$

where $\sigma$ and $\sigma_{0}$ are the strengths of the porous and nonporous bodies of the same material, respectively. $P$ is the porosity (expressed as a fraction). $B$ is the slope of the $\ln \sigma$ vs. $P$ curve (its value is about 7 ). It can be seen that there is a fundamental contradiction between high porosity and high strength. Therefore, effective measures should be taken to improve the strength of a sample with superhigh porosity. In other words, an outstanding thermal insulation material can be prepared based on the following two aspects: high porosity and high strength. The in-situ foamgelcasting-freeze drying method and fiber strengthening are therefore combined to realize both high porosity and high strength simultaneously.

In general, the strengthening phase should not react with the matrix. Wu et al. ${ }^{30)}$ therefore chose YSZ fiber, with low thermal conductivity and high high-temperature resistance, to enhance the strength of porous $\gamma-\mathrm{Y}_{2} \mathrm{Si}_{2} \mathrm{O}_{7}$ ceramic. From the XRD pattern shown in Fig. 34, it is observed that the YSZ fiber stably coexists with the porous $\gamma-\mathrm{Y}_{2} \mathrm{Si}_{2} \mathrm{O}_{7}$ matrix, and no new phase is detected. The as-prepared porous samples obtained through the in-situ foam-gelcasting-freeze drying method have very high porosities, $92.7 \%-93.5 \%$, as listed in Table 9. The fiber-reinforced porous $\gamma-\mathrm{Y}_{2} \mathrm{Si}_{2} \mathrm{O}_{7}$ ceramic has indeed been reinforced in terms of its compressive strength (Table 9). The reasons why the strength is improved are the fiber is bonded tightly with the porous matrix, as shown in Fig. 35, and the YSZ fiber enhances the mechanical properties of the sample through bridging and crack deflection.

Interestingly, the addition of YSZ fiber not only increases the strength of the porous ceramic, but also reduces the thermal conductivity, as presented in Table 9. It is because YSZ fiber has a lower intrinsic thermal conductivity $(\sim 3 \mathrm{~W} /$ $(\mathrm{m} \cdot \mathrm{K}))$ than $\gamma-\mathrm{Y}_{2} \mathrm{Si}_{2} \mathrm{O}_{7}(\sim 5 \mathrm{~W} /(\mathrm{m} \cdot \mathrm{K}))$ at room temperature, ${ }^{45,108)}$ and there exists an interfacial thermal resistance between the fiber and the matrix. Moreover, the fiber-reinforced porous $\gamma-\mathrm{Y}_{2} \mathrm{Si}_{2} \mathrm{O}_{7}$ composite exhibits low density $\left(0.26-0.32 \mathrm{~g} / \mathrm{cm}^{3}\right)$ and low shrinkage $(6.6 \%-9.2 \%)$. Thus, YSZ fiber-reinforced porous $\gamma-\mathrm{Y}_{2} \mathrm{Si}_{2} \mathrm{O}_{7}$ ceramic has the merits of being lightweight (density $0.30 \mathrm{~g} / \mathrm{cm}^{3}$ ), a high compressive strength (1.35 $\mathrm{MPa})$, and a low thermal conductivity $(0.090 \mathrm{~W} /(\mathrm{m} \cdot \mathrm{K}))$, which make it a promising high-temperature thermal insulation material.

Table 9. Shrinkage, Density, Porosity, Strength, and Thermal Conductivity of Porous $\gamma-\mathrm{Y}_{2} \mathrm{Si}_{2} \mathrm{O}_{7}$ with Different Contents of YSZ Fibers. Reproduced with permission from reference. ${ }^{30)}$

\begin{tabular}{cccccc}
\hline $\begin{array}{c}\text { Amount of YSZ fibers } \\
\text { added }(\%)\end{array}$ & $\begin{array}{c}\text { Shrinkage } \\
(\%)\end{array}$ & $\begin{array}{c}\text { Bulk density } \\
\left(\mathrm{g} / \mathrm{cm}^{3}\right)\end{array}$ & Porosity (\%) & $\begin{array}{c}\text { Compressive strength } \\
(\mathrm{MPa})\end{array}$ & $\begin{array}{c}\text { Thermal conductivity } \\
(\mathrm{W} /(\mathrm{m} \cdot \mathrm{K}))\end{array}$ \\
\hline 0 & $9.2 \pm 0.4$ & $0.26 \pm 0.01$ & $93.5 \pm 0.1$ & $0.99 \pm 0.22$ & 0.107 \\
10 & $7.4 \pm 0.3$ & $0.27 \pm 0.01$ & $93.5 \pm 0.1$ & $1.15 \pm 0.13$ & 0.092 \\
20 & $7.0 \pm 0.3$ & $0.30 \pm 0.01$ & $92.9 \pm 0.1$ & $1.35 \pm 0.16$ & 0.090 \\
30 & $6.6 \pm 0.2$ & $0.32 \pm 0.01$ & $92.7 \pm 0.1$ & $1.36 \pm 0.08$ & 0.097 \\
\hline
\end{tabular}

Content of solids: 15 vol.\% 

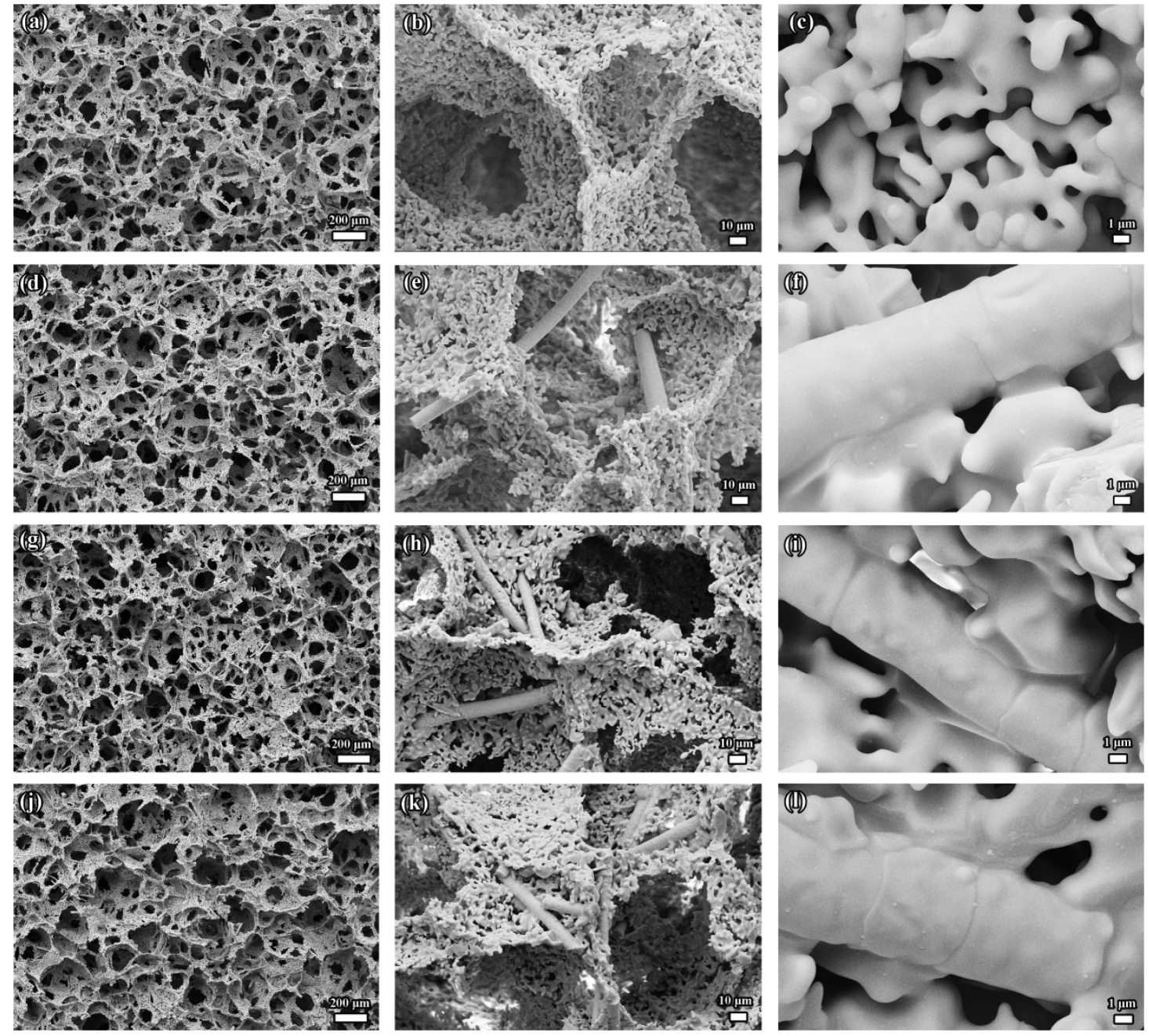

Fig. 35. SEM images of YSZ fiber-reinforced porous $\gamma-\mathrm{Y}_{2} \mathrm{Si}_{2} \mathrm{O}_{7}$ ceramic prepared by in-situ foam-gelcasting-freeze drying method: (a), (b), and (c) are the large pores, small pores, and grains, respectively, of 0 wt\% fiber; (d), (e), and (f) are the corresponding images (f shows the interface between the matrix and YSZ fiber) of $10 \mathrm{wt} \%$ fiber; $(\mathrm{g})$, (h), and (i) are the corresponding images of $20 \mathrm{wt} \%$ fiber; and (j), (k), and (l) are the corresponding images of $30 \mathrm{wt} \%$ fiber. Reproduced with permission from reference. ${ }^{30}$

\section{Challenges and Future Trends}

Owing to the existence of many other types of porous ceramic materials, porous rare earth silicate ceramics face a lot of competition and challenges. The features of porous rare earth silicate ceramics are good high-temperature resistance, good corrosion resistance, good phase stability, and low thermal conductivity. What is needed to be increased is the strength, especially the strength at higher porosities. However, at the same time, the low strength at high porosity is also a common problem with many other porous materials. In order to fabricate porous rare earth silicate ceramics with excellent thermal insulation performance and be used in large volumes in applications, various measures should be taken to improve the properties of porous rare earth silicate ceramics. The ultimate aim is to fabricate porous rare earth silicate thermal insulators that are lightweight and exhibit high strength, low thermal conductivity, and good high-temperature resistance.

Above all, in-situ reaction sintering is an effective approach to obtaining high-strength porous rare earth silicate ceramics, as indicated in this article. At present, only in-situ foamgelcasting and in-situ foam-gelcasting-freeze drying are employed to fabricate porous rare earth silicate ceramics. If TBA-based freeze casting, TBA-based gel-casting, waterbased freeze casting, and pore-forming agent methods are combined with in-situ reaction sintering, they offer great hope that porous rare earth silicate ceramics with novel pore structures, low densities, and high strengths can be successfully prepared. The poor mechanical properties resulted from direct sintering can be attributed to the fact that there perhaps exists some lattice defects between the rare earth silicate grains, when ball-milling rare earth silicate powders are used as raw materials. And the inadequate sintering would also lead to low strengths. However, the naturally generated grains, crystal boundaries, and sin- 


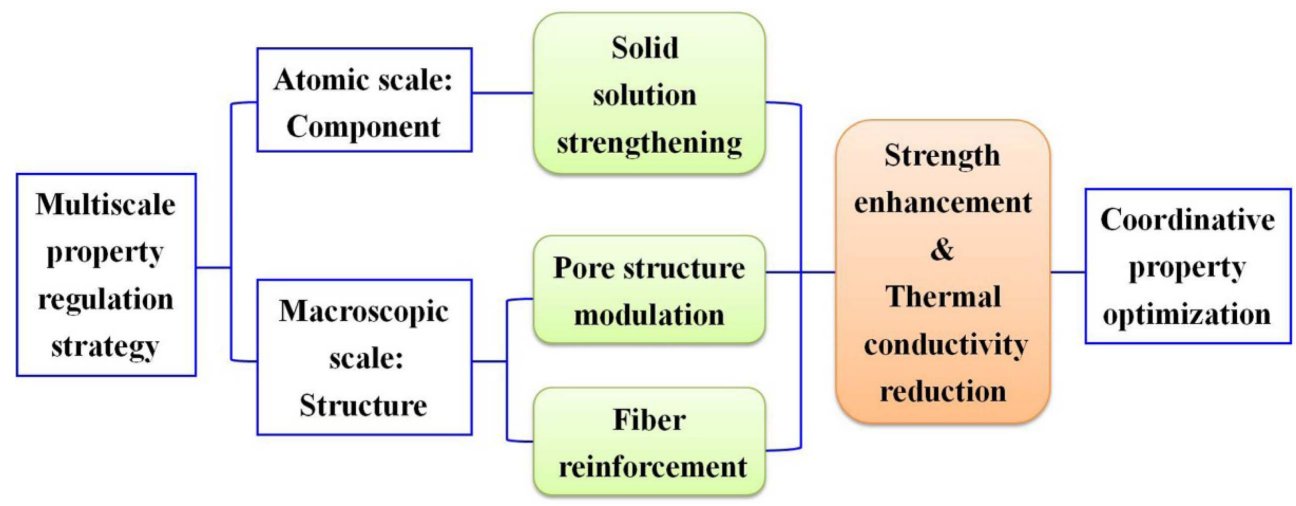

Fig. 36. Schematic diagram of multiscale property regulation strategy.

tering necks are optimal, firm, and tight. Furthermore, insitu reaction sintering can not only realize high strengths but also high porosities, low shrinkages, and low densities. Hence, utilization of in-situ reaction sintering for the fabrication of porous rare earth silicate ceramics is the general trend. A point to note is that the freezing speed must be reasonably controlled and delamination of the mixed starting powders should be necessarily avoided in the freeze casting techniques.

Besides, a few other measures can also be taken to improve the mechanical properties, such as solid strengthening, fiber reinforcement, second-phase reinforcement, and adjusting the pore structure. According to Gibson theory, ${ }^{78)}$ a porous material with a narrower pore size distribution would exhibit a higher strength than that with a larger pore size, for the same porosity. Therefore, the strength of porous rare earth silicate ceramics can be enhanced based on two aspects: through components on the atomic scale and through structure on the macroscopic scale. In other words, the mechanism of multiscale cooperative regulation can be utilized to collectively optimize the properties of porous rare earth silicate ceramics, as shown in Fig. 36. In particular, in order to simultaneously obtain high strength and superhigh porosity, the mechanism of multiscale cooperative regulation is of great importance.

Apart from the strength, it is also necessary to improve the other properties of porous rare earth silicate ceramics. An eminent solution is to prepare porous rare earth silicate composite materials (through the addition of fibers and a second phase). When the porous ceramic skeleton has good overall performances, the silica aerogel-impregnated porous rare earth silicate ceramics can have lower thermal conductivities as well as higher strengths, compared to nonimpregnated porous samples. $\mathrm{SiC}$ powder is sometimes added to thermal insulation materials to restrain heat radiation and reduce the thermal conductivity. Hence, porous rare earth silicate ceramics doped with $\mathrm{SiC}$ powder possibly reveal lower high-temperature thermal conductivity and can also be a good high-temperature thermal protection material. Furthermore, other preparation methods should also be employed to fabricate porous rare earth silicate ceramics. Thus, porous materials with new microstructures and good properties, including high porosity and low density, can be obtained.

\section{Conclusions}

The attractive properties of typical rare earth silicates, for example, good high-temperature resistance, good corrosion resistance, good phase stability, and low thermal conductivity, have been highlighted, and it has been found that rare earth silicates are excellent matrix materials for thermal insulators. The fabrication, microstructure, and properties of porous rare earth monosilicate ceramics and porous rare earth disilicate ceramics, as well as those of their composites, have been reviewed. At present, the preparation methods used for porous rare earth silicate ceramics are TBAbased freeze casting, TBA-based gel-casting, water-based freeze casting, pore-forming agent, polymeric sponge impregnation, in-situ foam-gelcasting, and in-situ foam-gelcastingfreeze drying. The methods of TBA-based freeze casting, TBA-based gel-casting, water-based freeze casting, and pore-forming agent resulted in porous ceramics with narrow pore size distributions. The porous samples fabricated by TBA-based freeze casting and water-based freeze casting have unidirectional pore structures, whereas those fabricated by the other preparation methods show isotropic pore structures. In-situ foam-gelcasting technique could realize porous rare earth silicate ceramics having high strengths and high porosities. On the other hand, in-situ foam-gelcasting-freeze drying could realize isotropous multiple pore structures with superhigh porosity and extremely low thermal conductivity. The in-situ reaction sintering process resulted in porous ceramics with lower sintering shrinkage, lower density, higher porosity, and higher strength than the porous samples obtained through the direct sintering process.

As for the existing porous rare earth silicate ceramics and their composites, these include porous $\mathrm{Y}_{2} \mathrm{SiO}_{5}$ ceramic, porous $\mathrm{Yb}_{2} \mathrm{SiO}_{5}$ ceramic, porous $\gamma-\mathrm{Y}_{2} \mathrm{Si}_{2} \mathrm{O}_{7}$ ceramic, porous $\gamma$ $\left(\mathrm{Y}_{1-\mathrm{x}} \mathrm{Ho}_{\mathrm{x}}\right)_{2} \mathrm{Si}_{2} \mathrm{O}_{7}$ solid solution, silica aerogel-impregnated porous $\mathrm{Y}_{2} \mathrm{SiO}_{5}$ ceramic, $\mathrm{ZrO}_{2}$ fiber-reinforced porous $\mathrm{Y}_{2} \mathrm{SiO}_{5}$ 
ceramic, and YSZ fiber-reinforced highly porous $\gamma-\mathrm{Y}_{2} \mathrm{Si}_{2} \mathrm{O}_{7}$ ceramic. Broadly speaking, porous rare earth silicate ceramics and their composites have the merits of good corrosion resistance, good phase stability, good thermal stability, being lightweight, low thermal conductivity, high porosity, and high strength at both room and high temperatures. In conclusion, porous rare earth silicate ceramics and their composites are excellent potential materials for high-temperature thermal insulators.

\section{Acknowledgments}

This work was financially supported by the National Key R\&D Program of China under grant no. 2017YFB0703201 and the Natural Science Foundation of China under the grant nos. 51372252 and 51772302.

\section{REFERENCES}

1. D. J. Green and R. Colombo, "Cellular Ceramics: Intriguing Structures, Novel Properties, and Innovative Applications," Mrs. Bull., 28 [4] 296-300 (2003).

2. M. Scheffler and P. Colombo, Cellular Ceramics: Structure, Manufacturing, Properties and Applications; Weinheim: Wiley-VCH, 2005.

3. T. Ohji and M. Fukushima, "Macro-Porous Ceramics: Processing and Properties," Int. Mater. Rev., 57 [2] 11531 (2012)

4. N. Sarkar, J. G. Park, S. Mazumder, C. G. Aneziris, and I. J. Kim, "Processing of Particle Stabilized $\mathrm{Al}_{2} \mathrm{TiO}_{5}-\mathrm{ZrTiO}_{4}$ Foam to Porous Ceramics," J. Eur. Ceram. Soc., 35 [14] 3969-76 (2015).

5. N. Sarkar, K. S. Lee, J. G. Park, S. Mazumder, C. G. Aneziris, and I. J. Kim, "Mechanical and Thermal Properties of Highly Porous $\mathrm{Al}_{2} \mathrm{TiO}_{5}$-Mullite Ceramics," Ceram. Int., 42 [2] 3548-55 (2016).

6. L. J. Gauckler, M. M. Waeber, C. Conti, and M. Jacobduliere, "Ceramic Foam for Molten-Metal Filtration," JOM, 37 [9] 47-50 (1985).

7. P. Colombo, "Ceramic foams: Fabrication, Properties and Applications," Key Eng. Mater., 206-213 1913-18 (2002).

8. J. Kitagawa, T. Hijikata, and K. Ishikawa, "Ceramic Honeycomb Filter for Purifying Exhaust Gases"; U.S. Patent 4,857,089, 1989.

9. P. Colombo, "In Praise of Pores," Science, 322 [5900] 38183 (2008).

10. N. Sarkar, J. G. Park, S. Mazumder, A. Pokhrel, C. G. Aneziris, and I. J. Kim, "Effect of Amphiphile Chain Length on Wet Foam Stability of Porous Ceramics," Ceram. Int., 41 [3] 4021-27 (2015).

11. H. Xu, J. C. Liu, A. R. Guo, H. Y. Du, and Z. G. Hou, "Porous Silica Ceramics with Relatively High Strength and Novel Bi-Modal Pore Structure Prepared by a TBAbased Gel-Casting Method," Ceram. Int., 38 [2] 1725-29 (2012).

12. S. Mishra, R. Mitra, and M. Vijayakumar, "StructureProperty Correlation in Cellular Silica Processed through Hydrophobized Fused Silica Powder for Aerospace
Application," J. Alloy. Compd., 504 [1] 76-82 (2010).

13. H. Xu, J. C. Liu, H. Y. Du, A. R. Guo, and Z. G. Hou, "Preparation of Porous Silica Ceramics with Relatively High Strength by a TBA-based Gel-Casting Method," Chem. Eng. J., 183 504-9 (2012).

14. T. Shimizu, K. Matsuura, H. Furue, and K. Matsuzak, "Thermal Conductivity of High Porosity Alumina Refractory Bricks Made by a Slurry Gelation and Foaming Method," J. Eur. Ceram. Soc., 33 [15-16] 3429-35 (2013).

15. B. Nait-Ali, K. Haberko, H. Vesteghem, J. Absi, and D. S. Smith, "Preparation and Thermal Conductivity Characterisation of Highly Porous Ceramics: Comparison between Experimental Results, Analytical Calculations and Numerical Simulations," J. Eur. Ceram. Soc., 27 [2-3] 1345-50 (2007).

16. K. Mohanta, A. Kumar, O. Parkash, and D. Kumar, "Low Cost Porous Alumina with Tailored Microstructure and Thermal Conductivity Prepared Using Rice Husk and Sucrose," J. Am. Ceram. Soc., 97 [6] 1708-19 (2014).

17. L. L. Gong, Y. H. Wang, X. D. Cheng, R. F. Zhang, and H. P. Zhang, "Thermal Conductivity of Highly Porous Mullite Materials," Int. J. Heat Mass Transfer, 67 253-59 (2013).

18. J. H. She and T. Ohji, "Fabrication and Characterization of Highly Porous Mullite Ceramics," Mater. Chem. Phys., 80 [3] 610-14 (2003).

19. Y. F. Gu, X. Q. Liu, G. Y. Meng, and D. K. Peng, "Porous YSZ Ceramics by Water-based Gelcasting," Ceram. Int., 25 [8] 705-9 (1999).

20. L. F. Hu and C. A. Wang, "Effect of Sintering Temperature on Compressive Strength of Porous Yttria-Stabilized Zirconia Ceramics," Ceram. Int., 36 [5] 1697-701 (2010).

21. E. M. Levin, C. R. Robbins, and H. F. McMurdie, Phase Diagrams for Ceramists (1969 Supplement); p. 76, The American Ceramic Society Inc., Columbus, Ohio, 1969.

22. Z. Q. Sun, Y. C. Zhou, J. Y. Wang, and M. S. Li, "Thermal Properties and Thermal Shock Resistance of $\gamma-\mathrm{Y}_{2} \mathrm{Si}_{2} \mathrm{O}_{7}$, , J. Am. Ceram. Soc., 91 [8] 2623-29 (2008).

23. Z. Q. Sun, M. S. Li, and Y. C. Zhou, "Recent Progress on Synthesis, Multi-Scale Structure, and Properties of Y-SiO Oxides," Int. Mater. Rev., 59 [7] 357-83 (2014).

24. Z. L. Tian, L. Y. Zheng, J. M. Wang, P. Wan, J. N. Li, and J. Y. Wang, "Theoretical and Experimental Determination of the Major Thermo-Mechanical Properties of $\mathrm{RE}_{2} \mathrm{SiO}_{5}$ $(\mathrm{RE}=\mathrm{Tb}, \mathrm{Dy}, \mathrm{Ho}, \mathrm{Er}, \mathrm{Tm}, \mathrm{Yb}, \mathrm{Lu}$, and Y) for Environmental and Thermal Barrier Coating Applications," J. Eur. Ceram. Soc., 36 [1] 189-202 (2016).

25. D. Y. Li and M. S. Li, "Porous $\mathrm{Y}_{2} \mathrm{SiO}_{5}$ Ceramic with Low Thermal Conductivity," J. Mater. Sci. Technol., 28 [9] 799-802 (2012).

26. Z. G. Hou, J. C. Liu, H. Y. Du, H. Xu, A. R. Guo, and M. Wang, "Preparation of Porous $\mathrm{Y}_{2} \mathrm{SiO}_{5}$ Ceramics with Relatively High Compressive Strength and Ultra-Low Thermal Conductivity by a TBA-based Gel-Casting Method," Ceram. Int., 39 [2] 969-76 (2013).

27. R. B. Zhang, D. N. Fang, X. M. Chen, Y. M. Pei, Z. D. Wang, and Y. S. Wang, "Microstructure and Properties of Highly Porous $\mathrm{Y}_{2} \mathrm{SiO}_{5}$ Ceramics Produced by a New Waterbased Freeze Casting," Mater. Design, 46 746-50 (2013).

28. Z. Wu, L. C. Sun, and J. Y. Wang, "Effects of Sintering Method and Sintering Temperature on the Microstructure 
and Properties of Porous $\mathrm{Y}_{2} \mathrm{SiO}_{5}$, , J. Mater. Sci. Technol., 31 [12] 1237-43 (2015).

29. Z. Wu, L. C. Sun, Z. L. Tian, J. Y. Wang, J. N. Li, and Z. J. $\mathrm{Hu}$, "Preparation and Properties of Reticulated Porous $\gamma$ $\mathrm{Y}_{2} \mathrm{Si}_{2} \mathrm{O}_{7}$ Ceramics with High Porosity and Relatively High Strength," Ceram. Int., 40 [7] 10013-20 (2014).

30. Z. Wu, L. C. Sun, J. J. Pan, and J. Y. Wang, "Fiber Reinforced Highly Porous $\gamma-\mathrm{Y}_{2} \mathrm{Si}_{2} \mathrm{O}_{7}$ Ceramic Fabricated by Foam-Gelcasting-Freeze Drying Method," Scr. Mater., 146 331-34 (2018).

31. Z. Wu, W. P. Hu, Y. X. Luo, L. C. Sun, and J. Y. Wang, "Porous $\gamma-\left(\mathrm{Y}_{1-\mathrm{x}} \mathrm{Ho}_{\mathrm{x}}\right)_{2} \mathrm{Si}_{2} \mathrm{O}_{7}$ Thermal Insulator with Excellent High-Temperature Strength Retention and Very Low Thermal Conductivity," J. Eur. Ceram. Soc., 38 [9] 334753 (2018)

32. F. F. Lange, S. C. Singhal, and R. C. Kuznicki, "Phase Relations and Stability Studies in $\mathrm{Si}_{3} \mathrm{~N}_{4}-\mathrm{SiO}_{2}-\mathrm{Y}_{2} \mathrm{O}_{3}$ Pseudoternary System," J. Am. Ceram. Soc., 60 [5-6] 249-52 (1977).

33. L. J. Gauckler, H. Hohnke, and T. Y. Tien, "The System $\mathrm{Si}_{3} \mathrm{~N}_{4}-\mathrm{SiO}_{2}-\mathrm{Y}_{2} \mathrm{O}_{3}$, J. Am. Ceram. Soc., 63 [1-2] 35-37 (1980).

34. J. W. Nowok, J. P. Kay, and R. J. Kulas, "Thermal Expansion and High-Temperature Phase Transformation of the Yttrium Silicate $\mathrm{Y}_{2} \mathrm{SiO}_{5}$," J. Mater. Res., 16 [8] 2251-55 (2001).

35. J. G. Wang, S. J. Tian, G. B. Li, F. H. Liao, and X. P. Jing, "Preparation and X-ray Characterization of Low-Temperature Phases of $\mathrm{R}_{2} \mathrm{SiO}_{5}(\mathrm{R}=$ rare earth elements)," Mater. Res. Bull., 36 [10] 1855-61 (2001).

36. J. Felsche, "The Crystal Chemistry of the Rare Earth Silicates," Struct. Bonding, 13 99-197 (1973).

37. R. B. Zhang, B. Y. Han, D. N. Fang, and Y. H. Wang, "Porous $\mathrm{Y}_{2} \mathrm{SiO}_{5}$ Ceramics with a Centrosymmetric Structure Produced by Freeze Casting," Ceram. Int., 41 [9] 1151722 (2015)

38. R. J. He, Z. L. Qu, and X. M. Cheng, "Effects of Starch Addition Amount on Microstructure, Mechanical Properties and Room Temperature Thermal Conductivity of Porous $\mathrm{Y}_{2} \mathrm{SiO}_{5}$ Ceramics," Ceram. Int., 42 [2] 2257-62 (2016).

39. Z. Wu, L. C. Sun, J. J. Pan, and J. Y. Wang, "Highly Porous $\mathrm{Y}_{2} \mathrm{SiO}_{5}$ Ceramic with Extremely Low Thermal Conductivity Prepared by Foam-Gelcasting-Freeze Drying Method," J. Am. Ceram. Soc., 101 [3] 1042-47 (2018).

40. Z. Wu, L. C. Sun, P. Wan, J. N. Li, Z. J. Hu, and J. Y. Wang, "In situ Foam-Gelcasting Fabrication and Properties of Highly Porous $\gamma-\mathrm{Y}_{2} \mathrm{Si}_{2} \mathrm{O}_{7}$ Ceramic with Multiple Pore Structures," Scr. Mater., 103 6-9 (2015).

41. R. B. Zhang, B. Y. Han, and D. N. Fang, "New Multifunctional Porous $\mathrm{Yb}_{2} \mathrm{SiO}_{5}$ Ceramics Prepared by Freeze Casting," Ceram. Int., 42 [5] 6046-53 (2016).

42. B. Y. Han, R. B. Zhang, and D. N. Fang, "Preparation and Characterization of Highly Porous $\mathrm{Yb}_{2} \mathrm{SiO}_{5}$ Ceramics Using Water-based Freeze-Casting," J. Porous Mat., 23 [2] 56368 (2016).

43. Z. Wu, W. P. Hu, Y. X. Luo, L. C. Sun, and J. Y. Wang, "Porous $\gamma-\left(\mathrm{Y}_{1-\mathrm{x}} \mathrm{Ho}_{\mathrm{x}}\right)_{2} \mathrm{Si}_{2} \mathrm{O}_{7}$ Thermal Insulator with Excellent High-Temperature Strength Retention and Very Low Thermal Conductivity,” J. Eur. Ceram. Soc., 38 [9] 3347
53 (2018).

44. C. Michel, G. Buisson, and E. F. Bertaut, "Structure de $\mathrm{Y}_{2} \mathrm{SiO}_{5}, "$ CR. Hebd. Des. Sean. De L Acad. Sci. Serie. B, 264 [5] 397-99 (1967).

45. Y. X. Luo, J. M. Wang, J. Y. Wang, J. N. Li, and Z. J. Hu, "Theoretical Predictions on Elastic Stiffness and Intrinsic Thermal Conductivities of Yttrium Silicates," J. Am. Ceram. Soc., 97 [3] 945-51 (2014).

46. Z. L. Tian, C. F. Lin, L. Y. Zheng, L. C. Sun, J. L. Li, and J. Y. Wang, "Defect-Mediated Multiple-Enhancement of Phonon Scattering and Decrement of Thermal Conductivity in $\left(\mathrm{Y}_{\mathrm{x}} \mathrm{Yb}_{1-\mathrm{x}}\right)_{2} \mathrm{SiO}_{5}$ Solid Solution," Acta Mater., 144292 304 (2018).

47. Y. Ogura, M. Kondo, T. Morimoto, A. Notomi, and T. Sekigawa, "Oxygen Permeability of $\mathrm{Y}_{2} \mathrm{SiO}_{5}$, " Mater. Trans., 42 [6] 1124-30 (2001).

48. W. Y. Ching, L. Z. Ouyang, and Y. N. Xu, "Electronic and Optical Properties of $\mathrm{Y}_{2} \mathrm{SiO}_{5}$ and $\mathrm{Y}_{2} \mathrm{Si}_{2} \mathrm{O}_{7}$ with Comparisons to $\alpha-\mathrm{SiO}_{2}$ and $\mathrm{Y}_{2} \mathrm{O}_{3}$," Phys. Rev. B, 67 [24] 245108 (2003).

49. J. D. Webster, M. E. Westwood, F. H. Hayes, R. J. Day, R. Taylor, A. Duran, M. Aparicio, K. Rebstock, and W. D. Vogel, "Oxidation Protection Coatings for $\mathrm{C} / \mathrm{SiC}$ based on Yttrium Silicate," J. Eur. Ceram. Soc., 18 [16] 2345-50 (1998).

50. M. Aparicio and A. Duran, "Yttrium Silicate Coatings for Oxidation Protection of Carbon-Silicon Carbide Composites," J. Am. Ceram. Soc., 83 [6] 1351-55 (2000).

51. Z. Q. Sun, J. Y. Wang, M. S. Li, and Y. C. Zhou, "Mechanical Properties and Damage Tolerance of $\mathrm{Y}_{2} \mathrm{SiO}_{5}$," J. Eur. Ceram. Soc., 28 [15] 2895-901 (2008).

52. Z. Q. Sun, M. S. Li, and Y. C. Zhou, "Thermal Properties of Single-Phase $\mathrm{Y}_{2} \mathrm{SiO}_{5}$," J. Eur. Ceram. Soc., 29 [4] 55157 (2009).

53. H. M. Xiang, Z. H. Feng, and Y. C. Zhou, "Mechanical and Thermal Properties of $\mathrm{Yb}_{2} \mathrm{SiO}_{5}$ : First-Principles Calculations and Chemical Bond Theory Investigations," J. Mater. Res., 29 [15] 1609-19 (2014).

54. K. N. Lee, D. S. Fox, and N. P. Bansal, "Rare Earth Silicate Environmental Barrier Coatings for $\mathrm{SiC} / \mathrm{SiC}$ Composites and $\mathrm{Si}_{3} \mathrm{~N}_{4}$ Ceramics," J. Eur. Ceram. Soc., 25 [10] 1705-15 (2005).

55. H. Klemm, "Silicon Nitride for High-Temperature Applications," J. Am. Ceram. Soc., 93 [6] 1501-22 (2010).

56. J. Felsche, "Crystal Data on Polymorphic Disilicate $\mathrm{Y}_{2} \mathrm{Si}_{2} \mathrm{O}_{7}$," Naturwissenschaften, 57 [3] 127-28 (1970).

57. J. Ito and H. Johnson, "Synthesis and Study of Yttrialite," Am. Mineral., 53 [11-1] 1940-52 (1968).

58. J. Y. Wang, Y. C. Zhou, and Z. J. Lin, "Mechanical Properties and Atomistic Deformation Mechanism of $\gamma-\mathrm{Y}_{2} \mathrm{Si}_{2} \mathrm{O}_{7}$ from First-Principles Investigations," Acta Mater., 55 [17] 6019_ 26 (2007).

59. Z. Q. Sun, Y. C. Zhou, J. Y. Wang, and M. S. Li, “ $\gamma-\mathrm{Y}_{2} \mathrm{Si}_{2} \mathrm{O}_{7}$, a Machinable Silicate Ceramic: Mechanical Properties and Machinability," J. Am. Ceram. Soc., 90 [8] 2535-41 (2007).

60. Z. Q. Sun, M. S. Li, and Y. C. Zhou, "Kinetics and Mechanism of Hot Corrosion of $\gamma-\mathrm{Y}_{2} \mathrm{Si}_{2} \mathrm{O}_{7}$ in Thin-Film $\mathrm{Na}_{2} \mathrm{SO}_{4}$ Molten Salt," J. Am. Ceram. Soc., 91 [7] 2236-42 (2008).

61. Z. Q. Sun, M. S. Li, Z. P. Li, and Y. C. Zhou, "Hot Corrosion 
of $\gamma-\mathrm{Y}_{2} \mathrm{Si}_{2} \mathrm{O}_{7}$ in Strongly Basic $\mathrm{Na}_{2} \mathrm{CO}_{3}$ Molten Salt Environment," J. Eur. Ceram. Soc., 28 [1] 259-65 (2008).

62. Z. L. Tian, L. Y. Zheng, Z. J. Li, J. L. Li, and J. Y. Wang, "Exploration of the Low Thermal Conductivities of $\gamma$ $\mathrm{Y}_{2} \mathrm{Si}_{2} \mathrm{O}_{7}, \beta-\mathrm{Y}_{2} \mathrm{Si}_{2} \mathrm{O}_{7}, \beta-\mathrm{Yb}_{2} \mathrm{Si}_{2} \mathrm{O}_{7}$, and $\beta-\mathrm{Lu}_{2} \mathrm{Si}_{2} \mathrm{O}_{7}$ as Novel Environmental Barrier Coating Candidates," J. Eur. Ceram. Soc., 36 [11] 2813-23 (2016).

63. Y. G. Liu, P. Peng, M. H. Fang, and Z. H. Huang, " $\mathrm{Y}_{3-\mathrm{x}} \mathrm{Er}_{\mathrm{x}-}$ $\mathrm{Al}_{5} \mathrm{O}_{12}$ Aluminate Ceramics: Preparation, Thermal Properties and Theoretical Model of Thermal Conductivity," Adv. Eng. Mater., 14 [3] 170-77 (2012).

64. L. Guo, H. Guo, H. Peng, and S. K. Gong, "Thermophysical Properties of $\mathrm{Yb}_{2} \mathrm{O}_{3}$ Doped $\mathrm{Gd}_{2} \mathrm{Zr}_{2} \mathrm{O}_{7}$ and Thermal Cycling Durability of $\left(\mathrm{Gd}_{0.9} \mathrm{Yb}_{0.1}\right)_{2} \mathrm{Zr}_{2} \mathrm{O}_{7} / \mathrm{YSZ}$ Thermal Barrier Coatings," J. Eur. Ceram. Soc., 34 [5] 1255-63 (2014).

65. M. W. Barsoum, M. Ali, and T. El-Raghy, "Processing and Characterization of $\mathrm{Ti}_{2} \mathrm{AlC}, \mathrm{Ti}_{2} \mathrm{AlN}$, and $\mathrm{Ti}_{2} \mathrm{AlC}_{0.5} \mathrm{~N}_{0.5}$," Metall. Mater. Trans. A, 31 [7] 1857-65 (2000).

66. F. L. Meng, Y. C. Zhou, and J. Y. Wang, "Strengthening of $\mathrm{Ti}_{2} \mathrm{AlC}$ by Substituting Ti with V," Scr. Mater., 53 [12] 1369-72 (2005).

67. Y. C. Zhou, J. X. Chen, and J. Y. Wang, "Strengthening of $\mathrm{Ti}_{3} \mathrm{AlC}_{2}$ by Incorporation of $\mathrm{Si}$ to form $\mathrm{Ti}_{3} \mathrm{Al}_{1-\mathrm{x}} \mathrm{Si}_{\mathrm{x}} \mathrm{C}_{2}$ Solid Solutions," Acta Mater., 54 [5] 1317-22 (2006).

68. Z. Wu, L. C. Sun, and J. Y. Wang, "Synthesis and Characterization of Porous $\mathrm{Y}_{2} \mathrm{SiO}_{5}$ with Low Linear Shrinkage, High Porosity and High Strength," Ceram. Int., 42 [13] 14894902 (2016).

69. R. B. Zhang, Q. Qu, B. Y. Han, and B. L. Wang, "A Novel Silica Aerogel/Porous $\mathrm{Y}_{2} \mathrm{SiO}_{5}$ Ceramics with Low Thermal Conductivity and Enhanced Mechanical Properties Prepared by Freeze Casting and Impregnation," Mater. Lett., 175 219-22 (2016).

70. R. B. Zhang, S. H. Li, and C. S. Ye, "Fabrication and Properties of Machinable Porous $\mathrm{ZrO}_{2 f} / \mathrm{Y}_{2} \mathrm{SiO}_{5}$ Nanocomposites Prepared by a Simple Method," J. Alloys Compd., 712 445-50 (2017).

71. R. F. Chen, C. A. Wang, Y. Huang, L. G. Ma, and W. Y. Lin, "Ceramics with Special Porous Structures Fabricated by Freeze-Gelcasting: Using Tert-Butyl Alcohol as a Template," J. Am. Ceram. Soc., 90 [11] 3478-84 (2007).

72. R. F. Chen, Y. Huang, C. A. Wang, and J. Q. Qi, "Ceramics with Ultra-Low Density Fabricated by Gelcasting: An Unconventional View," J. Am. Ceram. Soc., 90 [11] 342429 (2007).

73. J. L. Yang, J. L. Yu, and Y. Huang, "Recent Developments in Gelcasting of Ceramics," J. Eur. Ceram. Soc., 31 [14] 2569-91 (2011).

74. L. F. Hu, C. A. Wang, and Y. Huang, "Porous YttriaStabilized Zirconia Ceramics with Ultra-Low Thermal Conductivity," J. Mater. Sci., 45 [12] 3242-46 (2010).

75. S. Akamine and M. Fujita, "Controlling Heat Radiation for Development of High-Temperature Insulating Materials," J. Eur. Ceram. Soc., 34 [15] 4031-36 (2014).

76. D. N. Trivic, T. J. O'Brien, and C. H. Amon, "Modeling the Radiation of Anisotropically Scattering Media by Coupling Mie Theory with Finite Volume Method," Int. J. Heat Mass Tran., 47 [26] 5765-80 (2004).

77. J. J. Zhao, Y. Y. Duan, X. D. Wang, X. R. Zhang, Y. H.
Han, Y. B. Gao, Z. H. Lv, H. T. Yu, and B. X. Wang, "Optical and Radiative Properties of Infrared Opacifier Particles Loaded in Silica Aerogels for High Temperature Thermal Insulation," Int. J. Therm. Sci., 70 54-64 (2013).

78. L. J. Gibson and M. F. Ashby, Cellular Solids: Structure and Properties; Cambridge: Cambridge University Press, 1997.

79. E. Ryshkewitch, "Compression Strength of Porous Sintered Alumina and Zirconia," J. Am. Ceram. Soc., 36 [2] 65-68 (1953).

80. T. Fukasawa, M. Ando, T. Ohji, and S. Kanzaki, "Synthesis of Porous Ceramics with Complex Pore Structure by Freeze-Dry Processing," J. Am. Ceram. Soc., 84 [1] 23032 (2001).

81. Y. Zhang, K. H. Zuo, and Y. P. Zeng, "Effects of Gelatin Addition on the Microstructure of Freeze-Cast Porous Hydroxyapatite Cerarmics," Ceram. Int., 35 [6] 2151-54 (2009).

82. U. G. K. Wegst, M. Schecter, A. E. Donius, and P. M. Hunger, "Biomaterials by Freeze Casting," Philos. Trans. R. Soc., A, 368 [1917] 2099-121 (2010).

83. L. F. Hu, C. A. Wang, Y. Huang, C. C. Sun, S. Lu, and Z. J. Hu, "Control of Pore Channel Size during Freeze Casting of Porous YSZ Ceramics with Unidirectionally Aligned Channels Using Different Freezing Temperatures," J. Eur. Ceram. Soc., 30 [16] 3389-96 (2010).

84. O. Lyckfeldt and J. M. F. Ferreira, "Processing of Porous Ceramics by 'Starch Consolidation'," J. Eur. Ceram. Soc., 18 [2] 131-40 (1998).

85. H. M. Alves, G. Tarì, A. T. Fonseca, and J. M. F. Ferreira, "Processing of Porous Cordierite Bodies by Starch Consolidation," Mater. Res. Bull., 33 [10] 1439-48 (1998).

86. H. L. Zhang, J. F. Li, and B. P. Zhang, "Microstructure and Electrical Properties of Porous PZT Ceramics Derived from Different Pore-Forming Agents," Acta Mater., 55 [1] 171-81 (2007).

87. L. N. Wu, Y. D. Huang, Z. J. Wang, and L. Liu, "Controlled Fabrication of Porous $\mathrm{Al}_{2} \mathrm{O}_{3}$ Ceramic by N,N'Dimethylformamide-based Gel-Casting," Scr. Mater., 62 [8] 602-5 (2010).

88. L. Qian and H. F. Zhang, "Controlled Freezing and Freeze Drying: A Versatile Route for Porous and Micro-/NanoStructured Materials," J. Chem. Technol. Biotechnol., 86 [2] 172-84 (2011).

89. M. H. Ho, P. Y. Kuo, H. J. Hsieh, T. Y. Hsien, L. T. Hou, J. Y. Lai, and D. M. Wang, "Preparation of Porous Scaffolds by Using Freeze-Extraction and Freeze-Gelation Methods," Biomaterials, 25 [1] 129-38 (2004).

90. A. S. Dorcheh and M. H. Abbasi, "Silica Aerogel; Synthesis, Properties and Characterization," J. Mater. Process. Technol., 199 [1-3] 10-26 (2008).

91. M. Schmidt and F. Schwertfeger, "Applications for Silica Aerogel Products," J. Non-Cryst. Solids, 225 [1] 364-68 (1998).

92. A. C. Pierre and G. M. Pajonk, "Chemistry of Aerogels and Their Applications," Chem. Rev., 102 [11] 4243-65 (2002).

93. M. Diaz, C. Pecharroman, F. del Monte, J. Sanz, J. E. Iglesias, J. S. Moya, C. Yamagata, and S. Mello-Castanho, "Synthesis, Thermal Evolution, and Luminescence Properties 
of Yttrium Disilicate Host Matrix," Chem. Mater., 17 [7] 1774-82 (2005).

94. S. Kumar and C. H. Drummond, "Crystallization of Various Compositions in the $\mathrm{Y}_{2} \mathrm{O}_{3}-\mathrm{SiO}_{2}$ System," J. Mater. Res., 7 [4] 997-1003 (1992).

95. Z. Q. Sun, Y. C. Zhou, and M. S. Li, "Low-Temperature Synthesis and Sintering of $\gamma-\mathrm{Y}_{2} \mathrm{Si}_{2} \mathrm{O}_{7}$, J. Mater. Res., 21 [6] 1443-50 (2006).

96. T. Fukasawa, Z. Y. Deng, M. Ando, T. Ohji, and S. Kanzaki, "Synthesis of Porous Silicon Nitride with Unidirectionally Aligned Channels Using Freeze-Drying Process," J. Am. Ceram. Soc., 85 [9] 2151-55 (2002).

97. X. W. Zhu, D. L. Jiang, and S. H. Tan, "Preparation of Silicon Carbide Reticulated Porous Ceramics," Mater. Sci. Eng., A, 323 [1-2] 232-38 (2002).

98. R. Barea, M. I. Osendi, J. M. F. Ferreira, and P. Miranzo, "Thermal Conductivity of Highly Porous Mullite Material," Acta Mater., 53 [11] 3313-18 (2005).

99. P. Sepulveda and J. G. P. Binner, "Processing of Cellular Ceramics by Foaming and in situ Polymerisation of Organic Monomers," J. Eur. Ceram. Soc., 19 [12] 2059-66 (1999).

100. S. Joschek, B. Nies, R. Krotz, and A. Göpferich, "Chemical and Physicochemical Characterization of Porous Hydroxyapatite Ceramics Made of Natural Bone," Biomaterials, 21 [16] 1645-58 (2000).
101. M. Fukushima and Y. I. Yoshizawa, "Fabrication of Highly Porous Silica Thermal Insulators Prepared by GelationFreezing Route," J. Am. Ceram. Soc., 97 [3] 713-17 (2014).

102. Z. Wu, L. C. Sun, P. Wan, and J. Y. Wang, "Preparation, Microstructure and High Temperature Performances of Porous $\gamma-\mathrm{Y}_{2} \mathrm{Si}_{2} \mathrm{O}_{7}$ by in situ Foam-Gelcasting Using Gelatin," Ceram. Int., 41 [10, Part B] 14230-38 (2015).

103. X. W. Zhu, D. L. Jiang, and S. H. Tan, "Reaction Bonding of Open Cell $\mathrm{SiC}-\mathrm{Al}_{2} \mathrm{O}_{3}$ Composites," Mater. Res. Bull., 36 [11] 2003-15 (2001).

104. X. W. Zhu, D. L. Jiang, S. H. Tan, and Z. Q. Zhang, "Improvement in the Strut Thickness of Reticulated Porous Ceramics," J. Am. Ceram. Soc., 84 [7] 1654-56 (2001).

105. I. Nettleship, "Applications of Porous Ceramics," Key Eng. Mater., 122-124 305-24 (1996).

106. U. Soy, A. Demir, and F. Caliskan, "Effect of Bentonite Addition on Fabrication of Reticulated Porous SiC Ceramics for Liquid Metal Infiltration," Ceram. Int., 37 [1] 15-19 (2011).

107. Y. W. Kim, Y. J. Jin, Y. S. Chun, I. H. Song, and H. D. Kim, "A Simple Pressing Route to Closed-Cell Microcellular Ceramics," Scr. Mater., 53 [8] 921-25 (2005).

108. M. R. Winter and D. R. Clarke, "Oxide Materials with Low Thermal Conductivity," J. Am. Ceram. Soc., 90 [2] 533-40 (2007). 